Angelina Raičković

Arheološki institut Beograd

araickovic@yahoo.com

Bebina Milovanović

Arheološki institut Beograd

UDK 902.01(497.11)"2007”;

904:738(497.11)"01/03"

Izvorni naučni članak

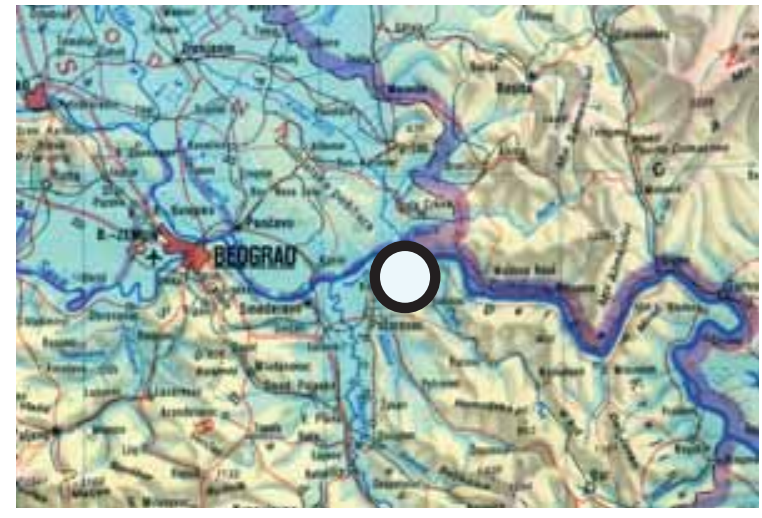

Viminacium, Stari Kostolac, Srbija

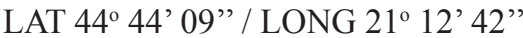

\title{
REZULTATI ISTRAŽIVANJA JUGOZAPADNOG DELA LOKALITETA PIRIVOJ (VIMINACIJUM)
}

\begin{abstract}
APSTRAKT
Na prostoru sonde 29, u neposrednoj blizini nekropole Pirivoj na Viminacijumu, konstatovana je površina koja je prvo definisana kao kulina ili žrtvena površina. Pošto ni ispod nje niti u njenoj neposrednoj blizini nisu nađeni grobovi, odustalo se od takvog tumačenja. Za sada možemo pretpostaviti da se radi o deponiji nastaloj učestalim nasipanjem materijala uklonjenog sa neke žrtvene površine u blizini. U slojevima crveno zapečene zemlje, glinovite i zemlje sa garom nađeni su mnogobrojni fragmenti keramičkih posuda i žižaka, delovi staklenih posuda, zatim ukrasne i šivaće igle od kosti $i$ bronze, bronzane i gvozdene alatke i bronzani novac. Prema nađenom materijalu deponija je datovana u period od početka II do početka IV veka.
\end{abstract}

KLJUČNE REČI: KERAMIČKe POSUde, ŽIŠCI, KOST, STAKLO, BRONZA, GVOŽĐE, KAMEN, NEKROPOLA, ViminaciJum.

Prilikom kopanja bazena ${ }^{1}$ za potrebe TE KO Drmno, početkom 2007. godine, tokom rada mehanizacije naišlo se na veću površinu sa zapečenom zemljom. Njene dimenzije su iznosile $22 \mathrm{x}$ $13 \mathrm{~m}$ i to je ustvari bio prostor sonde 29. Podeljen je na kvadrate dimenzija $5 \times 5 \mathrm{~m}$. Tačka A je na severu i dijagonala AC orijentisana je S-J (planovi br. 1 i 2). Nakon istraživanja celog prostora izdvojilo se više celina koje su se razlikovale kako

1 Istočno $(140 \mathrm{~m})$ od Mauzoleja buldozer je otkrio površinu dimenzija $10 \times 4 \mathrm{~m}$. Na relativnoj dubini od 0,50 $\mathrm{m}$ pojavila se zapečena zemlja te su radovi mehanizacije obustavljeni, a iznad prostora sa zapečenom zemljom postavljena je kvadratna mreža. Bazen sa linije bunara $\mathrm{V}$ je preimenovan u sondu 29, a sam bazen je izmešten. Zaštitna istraživanja ovog prostora, sprovedena od februara do novembra 2007. godine bila su pod rukovodstvom M. Koraća, naučnog savetnika Arheološkog instituta. po sastavu zemlje tako i po materijalu koji je u njima pronađen. Debljina velike površine crveno zapečene zemlje varira od 5 do $30 \mathrm{~cm}$. Ova površina se prostirala kroz kvadrate B/III, B/IV, C/I, C/II, C/III, C/IV, D/II, D/III, D/IV, E/II, E/III, E/ IV. Iznad površine sa crveno zapečenom zemljom, u kvadratima C/I, C/II, D/I, D/II, E/II nalazila se površina sa garom. U okviru te površine naišlo se na proslojke sa sivo zapečenom zemljom, tamnomrkom zemljom, šutom od sitno lomljene opeke, kao i na manje površine sa malterom. Površine sa malterom, debljine od 5-20 cm, javljaju se u kvadratima C/I, C/II, D/I i D/II, dok se površina sa sivo zapečenom zemljom prostire kroz kvadrate D/II, E/II i E/III. Ispod maltera se nalazio tanak sloj peska, a zatim sloj svetlo mrke boje. 


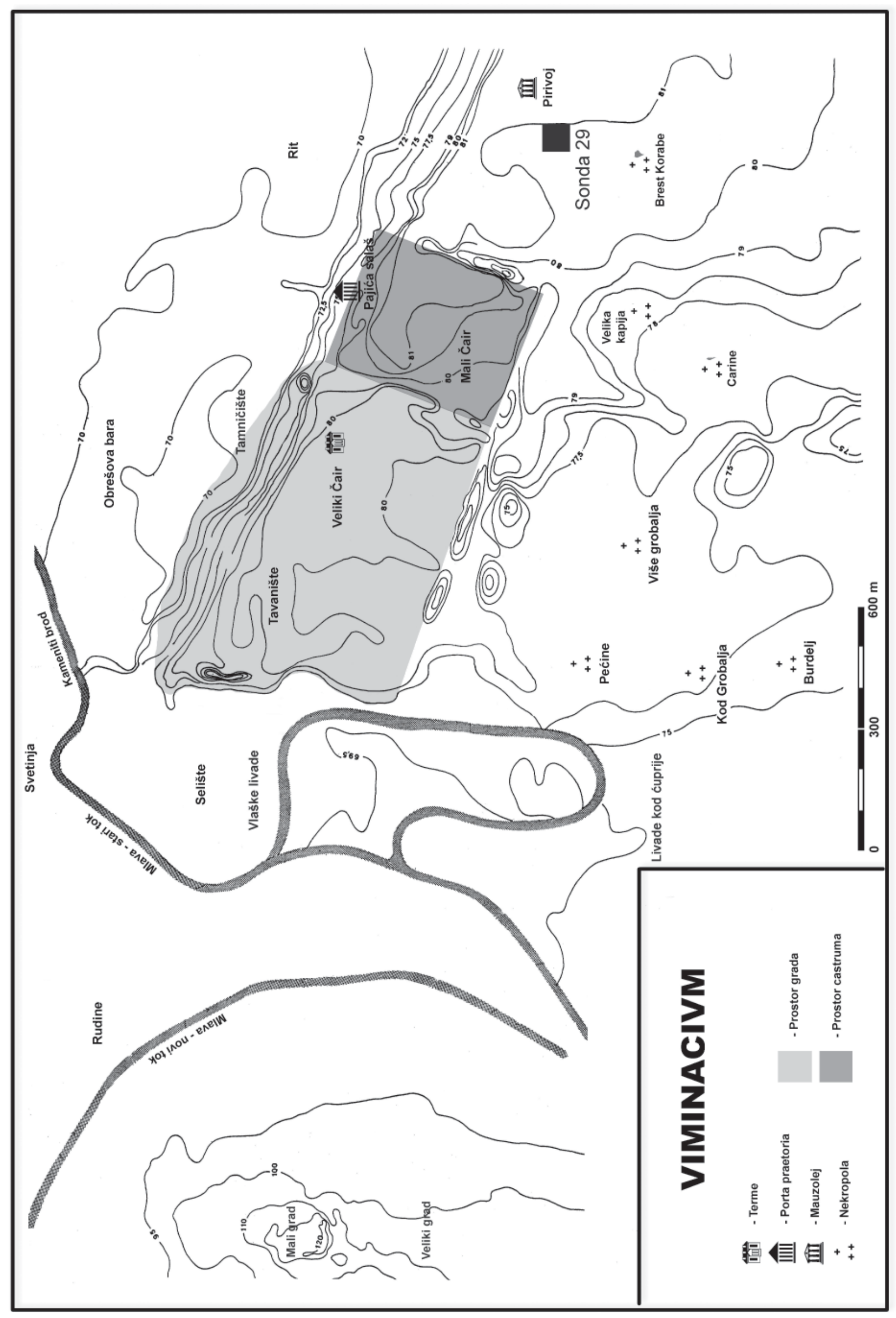


U okviru površine sa crveno zapečenom zemljom konstatovan je veći broj rupa, prečnika između 5 i $9 \mathrm{~cm}$, koje najverovatnije potiču od drvenog kolja.

Ispod crveno zapečene zemlje, nailazilo se na sloj mrke zemlje sa gareži, na svetlomrku i žutomrku zemlju, kao i na sloj tamnomrke zemlje, sa jakom koncentracijom gari, lomljenih opeka i tegula. Ispod sloja tamnomrke zemlje se naišlo na sloj mrkožute zemlje glinovitog do peskovitog sastava, dok je ispod mrkožute glinovite zemlje sloj tamnomrke zemlje sa jakom koncentracijom gari. U sloju žute zemlje u kvadratima C/IV i D/ IV konstatovan je rov, dužine oko $7 \mathrm{~m}$, i širine od $1,15-1,40 \mathrm{~m}$ koji se prostire u pravcu sever-jug. Severna površina rova bila je ukopana u crveno zapečenu zemlju. Rov se sastojao iz mrke zemlje, a u njemu je pronađena velika količina šuta od delova opeka, tegula i imbreksa sa vidljivim tragovima gorenja. Prostor rova datovan je na osnovu novčića (Maksimijan Herkulije) u kraj III i početak IV veka. Severno od granice velike površine sa crveno zapečenom zemljom, nalazio se veliki ukop nepravilnog oblika, koji se sastojao od mrke do tamnomrke zemlje koja se meša sa sivom glinovitom zemljom ili zemljom peskovito šljunkovitog sastava i proslojcima žute zemlje.

Najbrojniji i najraznovrsniji repertoar nalaza može se primetiti u keramičkom materijalu, a zatim slede brojni koštani nalazi. Pored keramičkih posuda i životinjskih kostiju, ${ }^{2}$ predmeti su podeljeni u devet grupa po materijalu od kojeg su napravljeni. Zbog svoje brojnosti i raznovrsnosti, keramičke posude su obrađene po sistemu koji se $i$ inače primenjuje $u$ obradi keramičkih posuda na Viminacijumu, ${ }^{3}$ a ostali nalazi su u daljem delu teksta predstavljeni kroz katalog sa opisom i crtežom ${ }^{4}$ kao i grafičkim prikazom količinske zastu-

2 Životinjske kosti su obrađene u posebnom radu u okviru ovog časopisa: S. Vuković, Ostaci životinja sa jugozapadnog dela lokaliteta Pirivoj, Viminacijum.

3 Keramički materijal je obrađen po metodološkim principima ustanovljenim u Sremskoj Mitrovici sedamdesetih godina, detaljnije: Bjelajac, 1978, 133-140. Od keramičkog materijala izdvojeno je 60 uzoraka koji su dati na petrološku i spektrohemijsku analizu laboratorijama Univerziteta u Rimu (Università degli Studi di Roma „La Sapienza"). Sastav gline bi mogao ukazati na mesta odakle je glina uzimana, odnosno na moguće radionice.

4 Keramičke posude na tablama date su u razmeri 1:4, a ostali materijal dat je u razmeri 2:3. Sav materijal iscrtala pljenosti pojedinih predmeta u okviru materijala od kojeg su napravljeni. ${ }^{5}$

\section{KERAMIČKE POSUDE (T. XVIII-XX/ 1-44)}

Prilikom istraživanja prostora koji obuhvata sonda 29 otkrivena je velika količina keramičkog materijala među kojim su najbrojnije posude. Od svih pregledanih i tipološki determinisanih oblika, najviše se javljaju zdele (zastupljene sa 64 tipa) zatim lonci (39), potom slede tanjiri (23), poklopci (20), pehari (12), amfore (10), kadionice (5), a pitosi i krčazi se nalaze na začelju (po 4 tipa). Ovakav odnos nije iznenađujući ako se posmatra sa stajališta kompletne viminacijumske tipologije. Ne bismo ga očekivali ako se ima u vidu blizina nekropole na Pirivoju i ako se polazi od ideje da je ovaj prostor bio odlagalište prilikom rasčišćavanja prostora za nove grobove. ${ }^{6}$ Radi preglednijeg $\mathrm{i}$ jasnijeg prikaza keramičke posude obrađene su po celinama koje su se izdvajale na prostoru Sonde 29, a kojih je do kraja istraživanja bilo 16 .

I. Površina iznad i površina sa crveno zapečenom zemljom u kvadratima C/II, C/III, D/III, E/ III, D/IV (Planovi 1 i 2)

Prostor od kojeg je početo istraživanje Sonde 29 nazvan je površina iznad i sa crveno zapečenom zemljom. Prostirala se kroz veći broj kvadrata i bila je nejednake debljine. Nađen je samo jedan novčić koji se datuje u II vek. Keramičke posude su brojne, a tipološki su najzastupljenije zdele. U ovoj celini javlja se nekoliko tipova takozvanih kaolinskih zdela, posuda rađenih od gline peskovite fakture čija je boja pečenja u tonovima beličaste i žućkasto beličaste boje (Munsell: 5YR$8 / 2$ ). To su zdele (T. XVIII, slika 1) koje mogu imati horizontalno, na spoljnu stranu izvučen užljebljeni obod i iskošen trbuh koji se spušta ka ravnom dnu. Od ovakve gline rađene su i zdele sa koso razgrnutim i užljebljenim obodom, iskošenim trbuhom ukrašenim širokim rebrima i ravnim

je Dragana Rogić. Planove iscrtala Ivana Grujić.

5 Grafikoni broj 1 i 2.

6 Naime, dosadašnjim proučavanjem priloga u grobovima na svim nekropolama Viminacijuma konstatovano je da se kao najbrojniji keramički prilozi, iako tipski siromašniji, javljaju krčazi. 


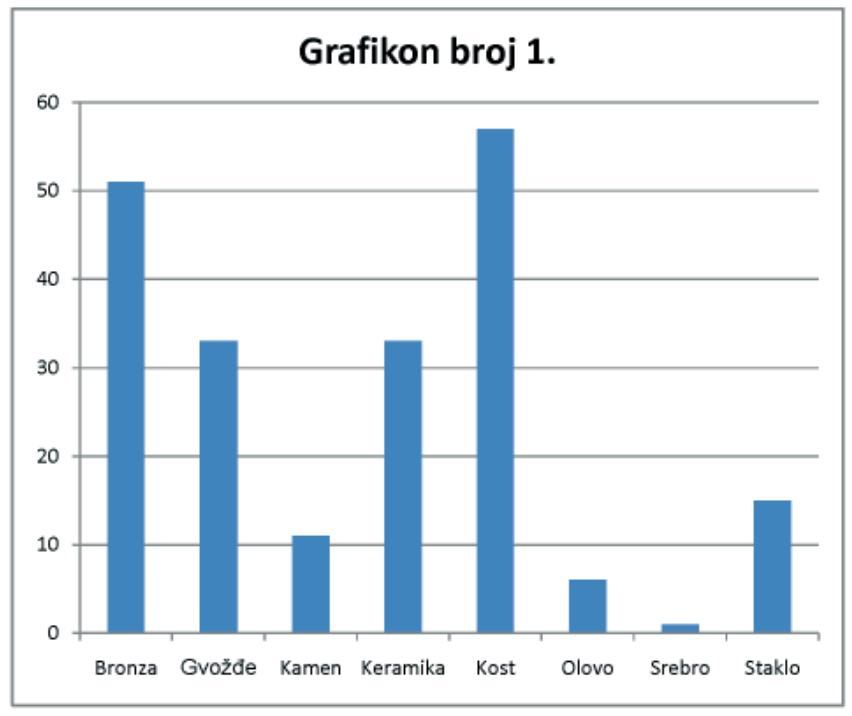

Grafikon br. 1

Grafički prikaz pronađenog materijala razvrstanog po materijalu od kojeg je napravljen

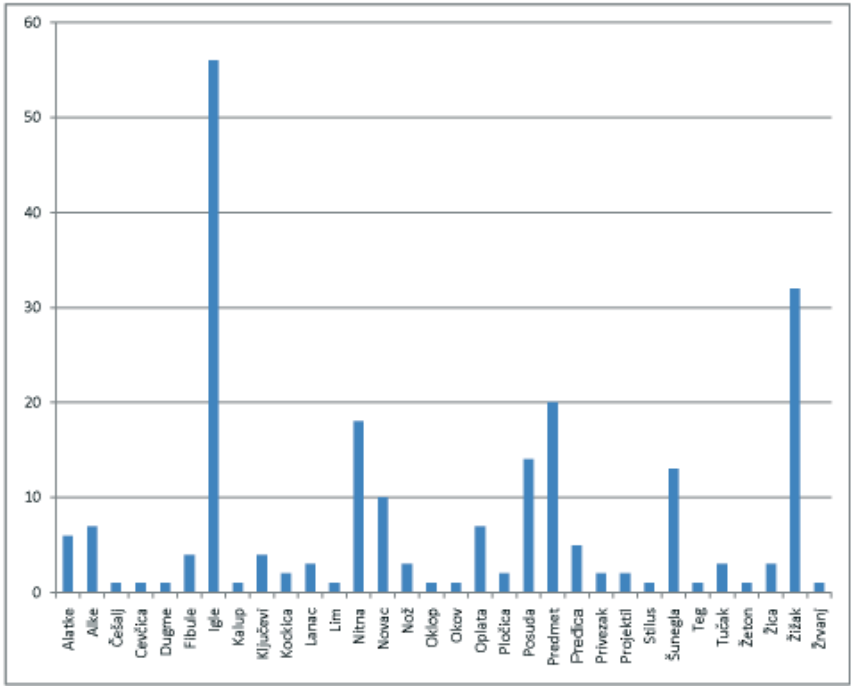

Grafikon br. 2

Grafički prikaz nađenog materijala razvrstanog po predmetima - funkciji

dnom. ${ }^{7}$ Treći tip zdela koji se ovde javlja, a isto je rađen od ovakve vrste gline su zdele sa horizontalno razgrnutim obodom koji je sa unutrašnje strane užljebljen (T. XVIII, slika 2). Trbuh je visoko postavljen i spušta se ka uskom ravnom dnu. Parne drške su trakasto užljebljene i postavljene ispod oboda, a završavaju se na gornjem delu trbuha gde počinje njegovo spuštanje ka dnu. $\mathrm{Na}$ ostalim lokacijama na Viminacijumu javlja se na lokalitetima Pećine i Kod Bresta-Korabe, gde je datovanje izvršeno uslovima nalaza od sredine II

7 Raičković 2007, T. I/9. do kraja III veka. Među zdelama koje su rađene od peskovite gline sivomrke boje pečenja i bez upotrebe vitla, potrebno je spomenuti šolju sa jednom drškom, neprofilisanog oboda kosih zidova trbuha i masivnog ravnog dna (T. XVIII, sl. 12). Spoljna površina ovih posuda je neobrađena i one se u literaturi nazivaju „dačkim šoljama”. Od zdela koje su rađene od srednje prečišćene gline crvene boje pečenja (Munsell: 5YR-6/6; 5YR7/6; 5YR-7/8), sa spoljnim površinama bojenim $\mathrm{u}$ tonovima crvene boje ili firnisom u tonovima crvene boje, najbrojnije su kalotaste zdele prste- 
nasto profilisanog oboda. ${ }^{8}$ Pored njih javljaju se i kalotaste zdele sa vertikalno izvučenim i blago uvučenim obodom ispod kojeg je plastična traka u vidu kragne. ${ }^{9}$ Sledeći tip zdele koji je zastupljen kako u ovoj tako i u svim ostalim celinama Sonde 29 , jeste zdela sa prstenasto profilisanim obodom i bikonično prelomljenim trbuhom (T. XVIII, sl. 4). Na prelomu trbuha je naglašena plastična traka. I one su rađene od srednje prečišćene gline u crvenoj boji pečenja, bojene ili firnisovane površine crvenom bojom. Ovaj oblik se javlja u širokom vremenskom intervalu u nekoliko varijanti sličnih karakteristika, ${ }^{10}$ a u literaturi im je čest naziv zdele ,patka tipa”. Prvi oblici su stigli putem importa. Paralele nalazimo u Gornjoj Meziji, Panoniji, Trakiji i Dakiji. ${ }^{11}$ Isto tako, javljaju se i manje kalotaste zdele uvučenog oboda i prstenastog užeg dna. Rađene su od srednje prečišćene gline crvene boje pečenja (Munsell: 2,5YR-6/8) i bojene spoljne površine koja može biti glačana ili firnisovana. ${ }^{12} \mathrm{U}$ manje zdele spada i tip sa vertikalno izvučenim i neprofilisanim obodom, sa ravnim zidovima trbuha koji se u gornjem delu lome ka uskom nenaglašenom dnu. Sa spoljašnje strane mogu biti ukrašene žljebom po vrhu oboda ili u gornjem delu trbuha. ${ }^{13} \mathrm{U}$ grupu manjih zdela spadala bi svakako i konična zdela sa ravnim dnom (T. XVIII, sl. 3) rađena po uzoru na formu Drag. 33, zatim manja zdela ,S” profilacije, koso razgrnutog oboda i naglašenog ramena, te prstenasto profilisanog dna (T. XVIII, sl. 16).

Slede potom plitke zdele sa kratkim, blago iskošenim i po ivici zaravnjenim obodom i blago zaobljenim zidovima trbuha koji se lome i skoro horizontalno spuštaju ka uskoj prstenastoj stopi i kod njih je spoljna površina bojena tonovima crvene boje, nekada glačana ili prevučena crvenim firnisom (T. XVIII, slika 7). Trbusi ovih zdela su ukrašeni ornamentom izvedenim radlom ili u tehnici barbotina. U pliće zdele spadaju i one sa zaobljenim i povijenim, na unutrašnju stranu

8 Raičković 2007, T. I/4.

9 Raičković 2007, T. III/39.

10 Raičković 2007, T. II/18.

11 Nikolić-Đorđević 2000, 18, tip I/3; Cvjetičanin 1996, tip I/19; Brukner 1981, T. 73/47, 51-55, tip I/11; Sultov 1985, 62, T. XXVI/1-3; Popilian 1976, Pl. XLII, XLIII/761-772.

12 Raičković 2007, T. II/19.

13 Raičković 2007, T. II/22. uvučenim zadebljanim obodom, sa blago iskošenim trbuhom i ravnim ili blago udubljenim dnom (XVIII, slika 13). Kod ovih zdela spoljašnja površina može ostati neobrađena, a i ako je bojena tonovima crvene ili mrke boje, često je ta boja nepostojana i lako se otire. Za ove zdele je karakteristično i to da se javljaju u različitim dimenzijama. Ne baš brojne, ali ipak dosta zastupljene u još nekoliko celina u sondi 29 su i zdele sa horizontalno razgrnutim, kratkim, po ivici zaobljenim obodom i ravnim zidovima trbuha, koji se od polovine lomi i koso spušta ka dnu. Ove posude su nekad ukrašene ornamentom koji je izveden radlom ili pečatima. ${ }^{14}$ Javlja se i plića zdela sa širokim trakasto profilisanim obodom i kosim zidovima trbuha. Rađena je od srednje prečišćene gline crvene boje pečenja i crveno bojene spoljne površine (T. XVIII, slika 14). Od većih zdela u ovoj celini se javljaju konične zdele prstenasto profilisanog i žljebovima dekorisanog oboda, debljih zidova rađenih od srednje prečišćene gline crvene boje pečenja i površine bojene crvenom bojom. Trbuh posude je ukrašen fasetiranjem i žljebovima. ${ }^{15}$ Isto tako ovde nailazimo i na dublje zdele sa koso izvedenim, prstenasto profilisanim i užljebljenim obodom, visoko postavljenim trbuhom i blago udubljenim dnom. Rađene su od peskovite gline, mrke ili sive boje pečenja (Munsell: 2,5YR-6/1) i neobrađene površine. Ponekad su na trbuhu izvedena rebra ili žljebovi (T. XVIII, slika 15). Tarionik ili mortarium, je oblik zdele široko razgrnutog i lučno savijenog oboda, sa zaobljenim zidovima trbuha i širokim ravnim dnom (T. XVIII, slika 17). Rađen je od srednje prečišćene gline crvene boje pečenja i neobrađene površine. Ogrubljivanje unutrašnjosti površine izvedeno je sitnijim i krupnijim kamenčićima. Na obodu postoji rebro koje prelazi u izlivnik. Po brojnosti tipova posle zdela u ovoj celini slede lonci. I među loncima se javlja podela na vrstu gline od koje su pravljeni kao i na samu funkciju lonca (trpezni, ognjišnji ili male ostave). Od ognjišnjih oblika ovde se javlja lonac horizontalno razgrnutog i sa unutrašnje strane užljebljenog oboda koji se spušta ka visoko postavljenom trbuhu i ravnom dnu (T. XIX, slika 18). Rađen je od peskovite gline, sive ili mrkosive boje pečenja i neobrađene je spoljašnje površine. U gornjem delu trbuh je ukrašen žljebovima. Sledi

14 Raičković 2007, T. II/15.

15 Raičković 2007, T. III/37. 
manji lonac koso profilisanog prstenastog oboda i bikoničnog trbuha, te ravnog nenaglašenog dna. ${ }^{16}$ Rađen najvećim delom od peskovite gline sive ili mrke boje pečenja i neobrađene spoljašnje površine. Čest oblik je lonac sa horizontalno izvučenim i pri krajevima blaže uvijenim obodom, naglašenog kratkog vrata i bikoničnog trbuha koji se spušta ka ravnom nenaglašenom dnu. Ovi lonci su rađeni od peskovite gline, sive boje pečenja i neobrađene spoljašnje površine. ${ }^{17}$ Najbrojnije zastupljeni lonci ove grupe su lonci trakasto profilisane ivice zaravnjenog oboda, koji je sa unutrašnje strane užljebljen (T. XIX, slika 22). Ispod oboda polazi trakasta drška koja je sa strane užljebljena. Bikoničan trbuh u gornjem delu ukrašen je plitkim žljebom. Rađeni su od peskovite gline sive boje pečenja i neobrađene površine.

Drugu grupu lonaca ovde prezentuje tip dubljeg i većeg lonca elipsastog, horizontalno razgrnutog otvora, koji se oštro lomi prema trbuhu. Rađen je od srednje prečišćene gline crvene boje pečenja i neobrađene spoljne površine (T. XIX, slika 20). ${ }^{18}$ Brojan je i na ostalim lokacijama na Viminacijumu. Jedini predstavnik lonaca rađenih od kaolinske gline jeste tip lonca užljebljenog, spolja zaobljenog oboda, rebrasto profilisanog trbuha i užeg ravnog dna naglašene ivice, neobrađene spoljne površine. Ispod oboda polazi jedna ili dve kratke široke trakaste drške (T. XIX, slika 19). Ovaj oblik je zastupljen na svim istraživanim lokacijama Viminacijuma, a karakteristično je za njega da su pronađene posude imale ponekad i funkciju urni. Dimenzije im variraju od sasvim malih $(7,5 \mathrm{~cm})$ do velikih $(25 \mathrm{~cm})$. Lonci ovog tipa se javljaju u dužem vremenskom intervalu, a njihova najveća koncentracija je na lokalitetima duž dunavskog dela limesa.

U grupu trpeznih lonaca iz ove celine izdvojili bismo jedan čest oblik koji se javlja na svim istraživanim lokacijama Viminacijuma i za koji sa sigurnošću možemo da potvrdimo da je i lokalni viminacijumski proizvod i isto tako omiljen u proizvodnji i upotrebi u dužem vremenskom periodu i to do prve polovine II pa do početka IV veka. Radi se o loncu horizontalno izvučenog kratkog oboda sa ravnim, cilindričnim vratom,

16 Raičković 2007, T. V/46.

17 Raičković 2005, T. V/52.

18 Po nekim autorima ove posude su služile kao ostave za hranu. loptastim trbuhom na nisko profilisanoj stopi. Ispod oboda polaze dve, užljebljene trakaste drške. Ponekad se javljaju i tri drške na loncu ovog tipa. Izrađuju se od srednje prečišćene zemlje crvene ili sive boje pečenja i spoljne površine bojene crveno ili crno. Može biti ukrašen pečatima, urezima ili fasetama. ${ }^{19}$ Analogije nalazimo na prostoru Singidunuma u okviru Gornje Mezije, a dosta ih ima na lokalitetima u Trakiji, Dakiji i Panoniji. ${ }^{20}$

Skoro polovina pronađenih oblika tanjira otkrivena je u crveno zapečenoj zemlji. Najbrojnije je zastupljen tanjir razgrnutog i na spoljnu stranu izvijenog oboda, profilisanog zida koji se lomi i koso povija prema prstenastom dnu ( $\mathrm{T}$. XIX, slika 26). Rađeni su od srednje prečišćene crveno pečene gline (Munsell: 2,5YR-6/8), bojeni crvenom bojom i uglačanih površina. Ovakvi tanjiri se javljaju na više lokacija na Viminacijumu gde su datovani u kraj II do sredina III veka. ${ }^{21}$ Prisutni su i tanjiri sa blago uvučenim zidovima trbuha koji se oštro lome ka ravnom dnu. Rađeni su od srednje prečišćene gline crvene boje pečenja i spoljne površine bojene crvenom bojom. ${ }^{22}$ Od većih tanjira tu se našao oblik sa trouglasto profilisanim uvučenim obodom i kosim zidovima trbuha koji se spuštaju ka nenaglašenom ravnom dnu. Rađeni su od peskovite gline žućkastobeličaste boje pečenja i neobrađene površine. ${ }^{23}$ Ovakve tanjire srećemo na više istraživanih lokacija na Viminacijumu, a u velikom broju se javljaju širom Dakije. ${ }^{24}$ Vrlo su česti i oblici plićeg tanjira sa uvučenim zaobljenim obodom i dnom koje je prstenasto profilisano do koga se spuštaju kosi zidova trbuha. ${ }^{25}$ Sa unutrašnje strane ima žljeb pri obodu. Rađeni su od srednje prečišćene gline crvene ili sive boje pečenja, površine koja je bojena tonovima crvene ili sive boje, glačane površine ili ponekad firnisovane. Po slojevima u kojima su nalaženi na drugim lokacijama na Viminacijumu, mogu se datovati u III vek, a paralele za ovaj tip

19 Raičković 2007, T. VI/69.

20 Nikolić-Đorđević 2000, 86, tip II/52; Sultov, 1985, 65, T. XXXVIII/1-8; Brukner 1981, T. 105/11-16; Popilian 1976, P1. XXXIX/394-404.

21 Analogije za ovaj tip nalazimo na Pontesu i u Singidunumu kada je u pitanju Mezija.

22 Raičković 2007, T. VIII/78.

23 Raičković 2007, T. VIII/79.

24 Nikolić-Đorđević 2000, 114, tip III/51; Popilian 1976, Pl. LXIX/853.

25 Raičković 2007, T. VIII/85. 
imamo na Pontesu, u Singidunumu i Sirmijumu. ${ }^{26}$ Po brojnosti slede tanjiri neprofilisanog oboda iskošenih zidova trbuha na spoljnu stranu koji se lome ka maloj prstenastoj stopi. ${ }^{27}$ Rađeni su od srednje prečišćene gline crvene ili mrke boje pečenja i bojene površine tonovima crvene ili mrke boje. Njihovo datovanje na drugim istraživanim lokacijama Viminacijuma na kojima se javljaju je kraj II i prva polovina III veka. Analogije za ovaj tip nalazimo na Pontesu i na lokalitetima u Trakiji. ${ }^{28} \mathrm{U}$ isti period i na istim lokacijama javljaju se još dva ovde pronađena oblika tanjira. Jedan od njih je sa razgrnutim i lučno izvijenim obodom koji na unutrašnjoj ivici oboda ima naglašeno rebro, a na spoljašnjoj ivici oboda žljeb. Kosi zidovi trbuha se nastavljaju na prstenastu stopu. ${ }^{29}$ Rađen je od srednje prečišćene gline crvene boje pečenja i bojene površine tonovima crvene ili mrke boje. Površina može biti prevučena firnisom crvene boje. Na dnu sa unutrašnje strane čest je ornament izveden pečačenjem i to u vidu stilizovanih listova koji su naspramno postavljeni između dva koncentrična kruga. Pored toga ornament može biti izveden i radlom. Drugi je oblik tanjir sa blago zaobljenim, na unutrašnju stranu uvučenim obodom i sa unutrašnje strane užljebljenim, kosim zidovima trbuha i nenaglašenim ravnim širokim dnom. ${ }^{30}$ Rađen je od srednje prečišćene gline crvene boje pečenja i bojen je crvenom bojom. Može se javiti i u peskovitoj fakturi kao i bojen sivom bojom. Ponekad može imati urezani ornament. Tanjir koji se javlja u ovoj i u svega još dve celine je oblik sa horizontalno razgrnutim obodom naglašene spoljne ivice, kosih zidova trbuha koji se lome ka široko postavljenom dnu (T. XIX, slika 27). Rađen je od srednje prečišćene gline crvene boje pečenja. Spoljna površina bojena je tonovima crvene boje.

Amfore se u ovoj celini javljaju u oblicima koji su i inače najbrojniji na Viminacijumu. Pre svih, to su amfore čiji je obod oštrije ili blaže profilisan, ravnog vrata, grla i trbuha debelih zido-

26 Garašanin, Vasić, Marjanović-Vujović 1984, T. I tip I/51; Nikolić-Đorđević 2000, 96, tip III/3; Brukner 1981, T. 73-20, tip III/14.

27 Raičković 2007, T. VIII/86.

28 Garašanin, Vasić, Marjanović-Vujović 1984, T. V tip III/6; Sultov 1983, T. XLVII/7.

29 Raičković 2007, T. VIII/89.

30 Raičković 2007, T. IX/94. va. Drške sa grla polaze do gornjeg dela trbuha. ${ }^{31}$ Pravljene od peskovite gline i neobrađene spoljne površine ili su ponekad premazane tankim slojem engobe žućkasto bele boje. U literaturi se često nazivaju Mirmekijskim amforama. Na ostalim viminacijumskim lokacijama ove amfore su datovane u period od sredine II do sredine III veka. Paralele za ovaj tip nalazimo u Singidunumu kao i na drugim mestima u Gornjoj Meziji i Dakiji. ${ }^{32}$ U velikom broju se javljaju i amfore zadebljanog i širokog, a blago uvučenog oboda, dužeg cilindričnog vrata od koga polaze dve naspramno postavljene masivne drške. ${ }^{33}$ Rađene su od srednje prečišćene crveno pečene zemlje sa žućkasto belom engobom. Po brojnosti zatim slede dve grupe amfora. Prve su amfore neprofilisanog oboda sa vratom na kojem su ili žljebovi ili rebra, a sa kojeg polaze i dve drške. Rađene su od srednje prečišćene gline crvene boje pečenja i površine bojene crvenom bojom. ${ }^{34}$ Drugi tip su amfore zadebljanog oboda i ravnog vrata sa kojeg polaze drške ovalnog preseka i spajaju se sa ramenom. Rađene su od srednje prečišćene gline crvene boje pečenja i spoljne površine bojene tonovima crvene ili mrke boje. ${ }^{35}$ I jedne i druge se na istraživanim lokacijama datuju u period od polovine II do polovine III veka.

Kada su u pitanju poklopci u ovoj celini nisu neđeni novi oblici. I ovde su najbrojniji poklopci zaobljenog oboda koji se koso spušta ka dugmetastoj dršci. Različitih su dimenzija i mrke ili sive boje pečenja, a zemlja je ili srednje prečišćena ili peskovita. ${ }^{36}$ Isto tako javlja se i poklopac u obliku zdele, oboda koso uvučenog i užljebljenog, čija je unutrašnja ivica naglašena, iskošenog zida trbuha i ravnog dna. Rađen je od sivo pečene gline, peskovite fakture i neobrađene površine. ${ }^{37}$ U manjem broju se javljaju poklopci zaobljenog uvučenog oboda sa kojih se zidovi lome ka dugmetastoj dršci. Rađeni su od peskovite gline sive boje pečenja i neobrađene površine. ${ }^{38}$ Manji i plići

31 Raičković 2007, T. X/96.

32 Nikolić-Đorđević 2000, 124, tip V/12; Bjelajac 1996, 106, tip XVIII; Popilian 1976, Pl. XVI/203, 204.

33 Raičković 2007, T. X/98.

34 Raičković 2007, T. X/101.

35 Raičković 2007, T. X/99.

36 Raičković 2007, T. XI/104.

37 Raičković 2007, T. XI/105.

38 Raičković 2007, T. XI/103. 
poklopac sa dugmetasto izvedenom drškom ređe se javlja. Rađen je od srednje prečišćene gline crvene boje pečenja sa tragovima žućkastobeličaste engobe. To je poklopac za amforu. ${ }^{39}$ Paralele za ovaj tip nalazimo kako u Meziji, isto tako i u Trakiji, Panoniji i Dakiji. ${ }^{40}$

Od ostalih oblika u ovoj celini se još javljaju samo tri tipa kadionica. Jedna od njih je kadionica dvostruko nazubljenog oboda, iskošenog trbuha ukrašenog jednom ili sa dve plastično nazubljene trake. Rađena je od srednje prečišćene zemlje, crvene boje pečenja sa belom engobom sa spoljašnje strane. ${ }^{41}$ Drugi tip je kadionica koničnih zidova trbuha na profilisanoj šupljoj nozi. Rađena je od srednje prečišćene zemlje crvene boje pečenja. Posuda je na obodu ukrašena nareckanim trakama koje su ravnomerno stiskane dok su zidovi trbuha rebrasti. ${ }^{42}$ Treći i poslednji tip kadionica koji se ovde javlja je manja kadionica blago razgrnutog nareckanog i užljebljenog oboda, zidova trbuha koji se bikonično spuštaju ka profilisanoj punoj stopi. Po sredini trbuha plastično je izvedena nareckana traka. Rađena od srednje prečišćene gline crvene boje pečenja i neobrađene je površine. U Viminacijumu ove kadionice se često javljaju i njihovo datovanje ide od kraja II do polovine III veka.

Sem jednog bronzanog novčića koji je opredeljen u II vek ono što bi moglo da pomogne u hronološkom određivanju ove celine jesu i nalazi terra sigillata posuda. U ovoj celini otkriven je 21 fragment od kojih je najznačajnije dno na kojem je sačuvan pečat sa natpisom fato fe. Ove posude su rađene od dobro prečišćene gline crvene boje pečenja i postojanog premaza, a od formi koje su ovde zastupljene najbrojnije se javlja oblik Drag. 37 (T. XX, slika 44). Sa obzirom da imamo sačuvano dno posude sa pečatom majstora pretpostavljamo da se radi o posudi koja spada u grupu glatkih tera sigilata posuda, najverovatnije oblik Drag. $31{ }^{43}$ a od ranije su nam poznati nalazi širom Mezije koji nose na sebi pečat ovog majsto-

39 Raičković 2007, T. XI/106.

40 Sultov 1985, 86, T. XLIV/3; Nikolić-Đorđević 2000, 155, tip VIII/4; Garašanin, Vasić, Marjanović-Vujović 1984, T. XIII tip VIII/9; Brukner 1981, T. 131/27; Popilian 1976, P1. LXXII/903.

41 Raičković 2007, T. XIV/118.

42 Raičković 2007, T. XIV/119.

43 Ova forma posuda najviše su proizvodile radionice u u Rajncabernu i Vestendorfu i to u periodu poslednje četvrtine II i prve četvrtine III veka. ra, pa možemo zaključiti da je ova tera sigilata iz Rajncaberna.

II. Ukop u kvadratima D/I - II (Plan 3)

Iz ove celine najzanimljivija posuda je fragmentovana amfora (T. XIX, sl. 33) rađena od peskovite gline, crvenomrke boje pečenja i neobrađene spoljne površine. Rebrastog je tela, na čijem grlu se nalaze tragovi kurziva izvedeni tamno crvenom bojom. Spada u grupu manjih amfora koje se ređe nalaze. ${ }^{44}$ Ovoj amfori nije moguće odrediti ni mesto porekla, ni sadržaj, a na osnovu delimično sačuvanog kurziva nije moguće dobiti potpunije podatke. Celina i amfora su datovane otkrivenim bronzanim novčićem u II vek. Od ostalih amfora u ovom sloju javlja se nekoliko oblika. Primerci jednog tipa pripadaju grupi čiji su centri proizvodnje i rasprostranjenost vezani za evropsku stranu Bosfora, obalu Crnog mora kao i oblasti donjeg toka Dunava. One se na prostoru Gornje Mezije u stratigrafski određenim slojevima intenzivno javljaju od sredine II do sredine III veka. Radi se o amforama čiji je obod oštrije ili blaže profilisan, grlo ravno, nekad malo povijeno, a trbuh blago zaobljen do široko loptast. Drške su postavljene odmah ispod oboda, a završavaju se na prelazu grla u trbuh. Dno ovih amfora je špicasto izvedeno, a rađene su od peskovite gline sa raznim primesama, boje pečenja u tonovima crvene, dok spoljašnja površina može biti neobrađena ili sa engobom. ${ }^{45}$ Sledeća grupa amfora koja se javlja u ovoj celini i čiji su fragmenti najbrojniji takođe spada u Pontske amfore zvonolikog otvora, dužih ili kraćih drški i širokog trbuha koji se završava malim špicastim dnom. Rađene su od srednje prečišćene gline crvene boje pečenja i spoljne površine premazane žućkastobeličastom engobom. ${ }^{46}$ Postoje dve varijante ovog tipa amfora, starija koja se datuje u period od druge polovine II do sredine III veka i mlađa koju karakteriše peskovitija glina, lošiji kvalitet izrade, svetlo braon boja pečenja i poroznija engoba i vremenski okvir trajanja od sredine III do početka IV veka. Kurziv na amforama koji se sreće u ovim celinama uglavnom je samo delimično sačuvan i uvek je izveden crvenom bojom preko žućkasto beličaste engobe (T. XX, slika 43).

44 Jedna na Viminacijumu na lokaciji Pećine i druga na Ravni, ali ni jednu nije bilo moguće datovati.

45 Bjelajac 1996, Sl. XX/ 106 - 114.

46 Bjelajac 1996, Sl. XVII/ $79-87$. 
III. Sivo zapečena zemlja u kvadratima E/ II-III dubina 0.80 - $1.60 \mathrm{~m}$ (Plan 4)

Ova celina je značajna jer je u njoj otkriven bronzani novčić Aleksandra Severa (222-235). Najbrojniji su fragmenti amfora i poklopaca kao i lonaca sa dve ili tri drške. Od lonaca rađenih od peskovite fakture, crvene ili sive boje pečenja i neobrađene spoljne površine javlja se lonac sa trouglasto profilisanim obodom, kratkim vratom i visoko postavljenim trbuhom (T. XIX, slika 21). Poseban je poklopac manjih dimenzija (T. XIX, slika 28), ravnog oboda ili na spoljnu stranu blago izvijenog, sa dugmetastom ili nepravilno izvučenom drškom. Rađen je od srednje prečišćene gline pečene u svetlijim crvenim ili oker tonovima, dok mu je površina prevučena žućkasto beličastom engobom. Ostali oblici koji se javljaju u ovoj celini već su već ranije opisani (T XVIII, slike 1, 10, 13, 17, T. XIX, slike 19, 22, 26).

IV. Površina sa gari i prostor južnog dela kvadrata D/II dubina $0.50-0.90 \mathrm{~m}$ (Plan 5)

U ovoj celini konstatovan je bronzani novčić koji je oštećen pa se samo moglo zaključiti da je u pitanju II vek. Konstatovani su fragmenti amfora i poklopaca, a od zdela koje nismo imali u prethodnim celinama izdvaja se (T. XVIII, slike 5) zdela sa koso razgrnutim užljebljenim obodom, zidovima blago zaobljenim i trbuhom koji se nisko lomi ka dnu. Ove posude su rađene od srednje prečišćene gline crvene ili sive boje pečenja i spoljašnje površine bojene firnisom $u$ istom tonu. Zidovi trbuha ukrašeni su ornamentom izvedenim barbotinom. Ovde se javlja i plića zdela blago iskošenih zidova trbuha sa širokim ravnim dnom. Obod joj je blago zaobljen na spoljnu stranu ili žljebom ukrašen sa unutrašnje strane. Rađena je od srednje prečišćene gline crvene ili sive boje pečenja i površine bojene crvenom ili sivom bojom i ponekad glačanom. ${ }^{47} \mathrm{Na}$ drugim lokacijama Viminacijuma zastupljena je na više mesta gde se datuje od kraja II do polovine III veka. Čest oblik je i kalotasta zdela (T. XVIII, slike 8) prstenasto, ređe trakasto profilisanog oboda i prstenasto modelovane stope. Rađena je od srednje prečišćene gline crvene boje pečenja, crveno bojene ili firnisovane površine.

47 Raičković 2007, T. II/25.
V. Svi kvadrati do dubine $1.60 \mathrm{~m}$

Celina je datovana novčićem u II vek. U njoj se izdvaja zdelica tanjih zidova nenaglašenog oboda, kalotastog trbuha koje se spušta ka prstenasto profilisanom dnu. ${ }^{48}$ Rađena od srednje prečišćene gline crvene ili sive boje pečenja, a spoljna površina bojena u nijansama od mrkocrvene pa sve do sive i crne boje. Često je posuda i glačana ili finisovana. Analogije za ovaj tip nalazimo širom Panonije. ${ }^{49} \mathrm{Ne}$ baš brojno javlja se kalotasta zdela sa vertikalno izvučenim i blago uvučenim obodom ispod kojeg je plastična traka u vidu kragne..$^{50}$ Rađena od srednje prečišćene zemlje crvene boje pečenja i bojene površine. Na ostalim lokacijama Viminacijuma javlja se u uslovima nalaza koji je datuju u kraj II, i prvu polovinu III veka. Analogije ovoj zdeli nalazimo u Singidunumu i na Pontesu. ${ }^{51}$ Od zdela u ovoj celini potrebno je izdvojiti i tip konične zdele sa horizontalno izvučenim rebrasto profilisanim obodom. Rađena je od srednje prečišćene gline, crvene boje pečenja i spoljne površine neobrađene (T. XVIII, slike 11). U ovoj grupi možemo izdvojiti i bikonični pehar (T. XX, slike 36) koso razgrnutog, kratkog oboda i blago konkavnog ili prstenastog dna. Sa jednom drškom koja polazi od oboda i spaja se na trbuhu. Rađen od crvene ili sivo pečene, srednje prečišćene gline. Površina može biti spolja glačana i bojena tonovima crvene, sive ili smeđe boje. Dosta je čest oblik pehara na Viminacijumu, a analogije za ovaj tip nalazimo u Singidunumu. Kadionice su u ovoj celini zastupljene sa oblikom koji ima horizontalno razgrnut obod koji je ukrašen talasasto modelovanim trakama od kojih je srednja najviša, a unutrašnja malo uvučena. Rađena je od srednje prečišćene gline, sa obe strane presvučena mat engobom koja se lako otire. ${ }^{52} \mathrm{Na}$ drugim lokacijama datuje se u II vek. Od kaolinske gline izrađen je krčag trolisnog otvora, blago zadebljanog, sa kojeg se spušta uže grlo ka visoko postavljenom trbuhu. Ispod oboda polazi trakasta užljebljena drška koja se završava na ramenu. Trbuh je rebrast i spušta se ka ravnom nenaglašenom dnu. ${ }^{53}$ Površi-

48 Raičković 2007, T. II/16.

49 Brukner 1981, T. 76/91-94.

50 Raičković 2007, T. III/39.

51 Nikolić-Đorđević 2000, 34, tip I/38; Garašanin, Vasić, Marjanović-Vujović 1984, T. I tip I/31.

52 Raičković 2007, T. XIV/121.

53 Raičković 2007, T. XV/128. 
na je neobrađena. Ovakvi krčazi se javljaju u dužem vremenskom periodu od sredine II do sredine IV veka. Za njih je karakteristično, kao i za već navedene lonce rađene od iste vrste gline da su nalaženi samo uz tokove Dunava i da analogija za njih u Panoniji nema, dok se u Meziji mogu naći u Singidunumu, a u većem broju u Dakiji. ${ }^{54}$

VI. Iz i oko površine sa malterom u kvadratima CD/II-III dubina $0.70-1.40$ m (Plan 6)

U ovoj celini pronađen je novčić Hadrijana. Nije bilo puno keramičkih posuda, a od oblika koji se izdvajaju svojom brojnošću su fragmenti amfora sa tragovima engobe i delovi lonaca sa cilindričnim vratom i trakasto postavljenim drškama. Ostali tipovi već su se javljali u ranijim celinama (T. XVIII, slike 8, 13, T. XIX slike 19, 20, 29).

VII. Površina sa sivom glinovitom zemljom (Plan 5)

Celina je datovana deformisanim novčićem (II-III vek). Javlja rukom rađeni lonac od peskovite gline, sivomrke boje pečenja i neobrađene spoljne površine. Isto tako javlja se i obod pitosa (T. XX, slike 34) sa horizontalno zaravnjenim kratkim obodom, ispod kojeg se zid trbuha lučno širi. Rađen od crvene, srednje prečišćene gline neobrađene spoljne površine. Ovaj tip se u okviru Viminacijuma javlja i na drugim lokacijama gde je datovanje uslovima nalaza određeno u period od od sredine II do sredine III veka. Analogije za ovaj tip nalazimo u Trakiji, Meziji i Panoniji. ${ }^{55}$ Od kadionica ovde se javlja tip (T. XX, slike 35) sa neprofilisanim nareckanim obodom i zaobljenim zidovima trbuha koji su ukrašeni talastastim trakama. Zidovi trbuha se spuštaju ka visokoj šupljoj nozi, koja se završava proširenom stopom. Rađena je od srednje prečišćene gline crvene boje pečenja, a površina je prevučena belom mat engobom.

\section{Rov u kvadratima CD/IV (Plan 7)}

Rov koji se proteže kroz kvadrate CD/IV je i hronološki najmlađi jer je u njemu konstatovan novčić Maksimijana (286-305) iz perioda tetrarhije. Od keramičkih posuda koje se izdvajaju u

54 Nikolić-Đorđević 2000, 135, tip VII/2; Brukner 1981, T. 146/139; Popilian 1976, Pl. XLIX/529.

55 Sultov 1985, 79, T. XXXIX/1; Nikolić-Đorđević 2000, 131, tip VI/6; Garašanin, Vasić, Marjanović-Vujović 1984, T. IX tip VI/4; Brukner 1981, T. 127/2. ovom rovu pored već čestih fragmenata amfora i zdela javlja se i plića, veća zdela trakasto profilisanog oboda i kosih zidova trbuha (T. XVIII, slika 13). Rađena je od peskovite gline sive boje pečenja i neobrađene spoljne površine. Od lonaca se javlja oblik sa prstenasto profilisanim, koso razgrnutim obodom i jajolikim trbuhom koji se spušta ka ravnom dnu. Rađen je od peskovite gline sa dosta primesa kvarca, mrkocrvene boje pečenja i neobrađene spoljne površine. ${ }^{56}$ Od peskovite gline sive boje pečenja i neobrađene spoljne površine je i tip lonca sa užljebljenim profilisanim obodom i naglašenim trbuhom koji se spušta ka dnu. Ovde se javlja i lonac sa horizontalno izvučenim kratkim obodom, kratkim ravnim vratom koji je žljebom odvojen od ovalnog trbuha, a završava se prstenastom stopom. Rađen je od srednje prečišćene gline crvene boje pečenja i površine bojene tonovima crvene boje. ${ }^{57}$ Poklopce u ovoj celini predstavlja dublji oblik zvonolike forme sa dugmetastom drškom, iskošenog i blago užljebljenog oboda. Rađen je od peskovite gline sive boje pečenja i neobrađene površine.

IX. Celina uz zapadni profil u kvadratima CD/II-III (Plan 8)

Ovu celinu hronološki određuje samo jedan novčić datovan u II vek. Svojim izgledom se izdvaja zdela - mortarium levkasto profilisanog oboda koji na spoljnoj strani ima široku traku u vidu kragne. Polusferičnog je recipijenta, rađen od srednje prečišćene gline crvene boje pečenja i spoljne površine bojene crvenim firnisom. Unutrašnjost mortarijuma je ogrubljena sitnim kamenčićima. Javlja se i grupa manjih zdela od kojih je jedna sa horizontalno razgrnutim obodom čija je trakasta ivica vertikalno postavljena i ima plitko zaobljen recipijent i dno u obliku iskošene stope. Rađena je od srednje prečišćene gline crvene boje pečenja i spoljne površine bojene crvenim firnisom. Druga mala zdela je tip lučno razgrnutog oboda, zaobljenog trbuha i prstenasto profilisanog dna. Rađena je od srednje prečišćene gline crvene boje pečenja, a površina je bojena crvenom bojom. Od plićih zdela javlja se tip sa uskim horizontalno razgrnutim užljebljenim obodom, blago iskošenim zidovima trbuha i ravnim, širokim dnom. Rađena je od peskovite gline sive boje pečenja i

56 Raičković 2007, T. V/54.

57 Raičković 2007, T. VII/72. 
neobrađene spoljašnje površine. Od dubljih zdela javlja se tip sa horizontalno izvučenim užljebljenim obodom i ravnim zidovima trbuha (T. XVIII, slika 9). Ove zdele rađene su od peskovite gline sivomrke boje pečenja i spolje površine neobrađene. Ornament je izveden u vidu jednog plitkog žljeba u gornjem delu trbuha. Ognjišni lonci u ovoj celini zastupljeni su tipom lonca trouglasto profilisanog oboda i loptastog trbuha (T. XIX, slika 23), rađeni od peskovite gline sive boje pečenja i neobrađene spoljne površine. Drugi oblik koji se javlja je lonac užljebljenog, izrazito profilisanog oboda, naglašenog trbuha i ravnog dna. Rađen je od peskovite gline, sive boje pečenja, neobrađene površine (T. XIX, slika 24). Nađeni su i fragmenti amfore od koje je sačuvan trakasto profilisan obod i dug cilindrični vrat (T. XIX, slika 32). Sa vrata polaze dve trakasto profilisane drške. Ovaj tip amfora karakteriše ravno dno, izrada od dobro prečišćene gline u kojoj su primese grumenova gline istog kvaliteta, svetlo crvena boja pečenja i delimično glačana spoljna površina. Na drugim lokacijama Viminacijuma gde je pronađena ovaj tip se datuje u period II-III veka. Od pitosa zastupljen je tip sa horizontalno razgrnutim obodom kratkim naglašenim vratom i zaobljenim trbuhom. Rađen je od peskovite gline crvene boje pečenja i neobrađene spoljne površine. Javljaju i tri tipa pehara od kojih je jedan već opisan (T. XX, slika 36), drugi čini pehar nenaglašenog oboda kosih zidova trbuha koji se lome ka prstenastoj stopi. Rađen je od srednje prečišćene gline, crvene boje pečenja i crveno je bojen, a spoljna strana mu je ukrašena urezima. Treći oblik je pehar (T. XX, slika 38) sa visokim recipijentom, trakasto profilisanim i blago užljebljenim obodom, kosih zidova trbuha koji se sužavaju prema dnu. Rađen je od peskovite gline sa primesama liskuna, sive boje pečenja i neobrađene površine.

X. Južni profil iskopa, kvadrati CE/IV dubina $0.10-1.00 \mathrm{~m}$ (Plan 7)

Nije nađen ni jedan novčić ili neki drugi predmet koji bi mogao preciznije da datuje sloj. Od keramičkih posuda koje se javljaju izdvojili bismo tanjir blago zaobljenog, na unutrašnju stranu uvučenog i sa unutrašnje strane užljebljenog oboda, kosih zidova trbuha i nenaglašenog ravnog širokog dna. ${ }^{58}$ Rađen od srednje prečišćene gline crvene boje pečenja i crveno je bojen. Može biti i peskovite fakture i sivo bojen. Ponekad ima urezani ornament. Na drugim istraživanim lokacijama Viminacijuma nalazimo ga u horizontima datovanim u period II veka. Javlja se nekoliko tipova poklopaca. Veći i dublji poklopac sa prstenasto profilisanim obodom, zidovima koji se zaobljeno spuštaju ka dnu i trbuhom ukrašenim žljebovima. Rađen je od srednje prečišćene ili peskovite gline, crvene, mrke ili sive boje pečenja. ${ }^{59}$ Ovaj tip se $u$ okviru Viminacijuma javlja na većem broju istraživanih lokacija, gde se datuje u prvu polovinu III veka. Zatim poklopac većeg prečnika kratkog horizontalnog, na spoljnu stranu profilisanog oboda, sa spoljašnje strane široko užljebljenog tako da nastaje blagi talas. Rađen je od peskovite gline sive i mrke boje pečenja, neobrađene površine. ${ }^{60}$ Treći tip je poklopac - zdela, sa profilisanim i na unutrašnju stranu savijenim obodom, kosih, blago izvijenih zidova trbuha sa dnom koje je ravno ili blago udubljeno. Rađen je od peskovite gline sive boje pečenja i neobrađene površine. Najzanimljiviji fragment ove celine je zvonoliki obod amfore od srednje prečišćene gline crvene boje pečenja i neobrađene spoljne površine, na kojem je utisnut retrogradni nečitak pečat (T. XIX, slika 31). Ovaj tip amfora je vezan za import iz zapadno mediteranskih oblasti. Ostali oblici posuda koji se javljaju već su opisani.

XI. Mrkožuta zemlja ispod crveno zapečene zemlje u kvadratima DE/III-IV (Plan 7)

U ovoj celini je pronađen novčić datovan u prvu polovinu II veka (Marcijana). Podjednako brojno se javljaju zdele, lonci kao i krčazi. Pored kaolinskog trolisnog krčaga javljaju se i fragmenti krčaga trolisnog otvora, kratkog grla koji se nastavlja na nisko spušteni trbuh. Trakasta užljebljena drška polazi ispod oboda i ide do sredine trbuha. Dno je prstenasto izvedeno. Po vratu i pri dnu trbuha nalazi se po jedan žljeb. Rađen je od srednje prečišćene gline crvene boje pečenja i crveno bojene spoljne površine. ${ }^{61}$ Od ostalih oblika izdvaja se pehar neprofilisanog oboda, kosih zidova trbuha koji je nisko spušten i lomi se ka

58 Raičković 2007, T. IX/94.

59 Raičković 2007, T. XI/108.

60 Raičković 2007, T. XI/110.

61 Raičković 2007, T. XV/131. 
uskoj stopi. Jedna drška polazi sa ivice oboda i završava se na sredini trbuha. Rađen je od srednje prečišćene gline crvene boje pečenja i crveno bojene površine. Drugi pehar koji je fragmentovan, rađen je od srednje prečišćene gline žućkasto bele boje pečenja čija je spoljna površina gleđosana. Fragment trbuha je ukrašen barbotinom.

XII. Sloj sa intenzivonom gari u kvadratima DE/III-IV (Plan 7)

Sledeća celina nije pružila nalaze koji bi bliže hronološki opredelili keramičke posude. Ono što se u ovoj celini izdvaja je zdela horizontalno razgrnutog i užljebljenog oboda i bikonično prelomljenog trbuha. Rađena je od srednje prečišćene gline sivomrke boje pečenja, neobrađene površine. ${ }^{62} \mathrm{U}$ okviru Viminacijuma javlja se i na prostoru nekropola i civilnog naselja, a uslovima nalaza datovana je u III vek. Sledi pitos horizontalno izvučenog oboda i sferičnog recipijenta. Rađen je o srednje prečišćene gline crvene boje pečenja, a spoljna površina je premazana smolastim premazom. Javlja se i nekoliko tipova pehara. Manji pehar neprofilisanog oboda, iskošenog trbuha koji se lomi ka uskoj prstenasto profilisanoj stopi, rađen je od srednje prečišćene gline crvene boje pečenja i spoljne površine bojene tonovima crvene boje. Zatim, manji pehar sa dve drške koje su postavljene ispod neprofilisanog oboda, bikoničnog trbuha koji se spušta ka ravnom ili blago udubljenom dnu, rađen od srednje prečišćene gline sive boje pečenja i spoljne površine premazane firnisom sive boje. Sledeći tip pehara je čest na Viminacijumu i javlja se u više varijanti. Uglavnom je sa jednom drškom, slabije ili jako razgrnutog oboda i loptastog trbuha na ravnom ili uskom naglašenom dnu (T. XX, slika 37). Rađen je od srednje prečišćene gline, sive boje pečenja i neobrađene spoljne površine, ali se isto tako javlja i rađen od žućkasto-beličaste gline kao i u crvenoj boji pečenja. Od krčaga izdvajamo još jedan tip trolisnog otvora neprofilisane ili užljebljene ivice i ovalnog do loptastog trbuha, na ravnom ili prstenastom dnu. Ispod oboda je smeštena trakasta drška koja je po sredini užljebljena. Drška se završava na ramenu (T. XX, slika 42). Rađen je od srednje prečišćene gline crvene boje pečenja i spoljne površine premazane crvenom bojom.
Hronološki nisu preterano osetljivi i na drugim lokacijama javljaju se od početka II do sredine IV veka.

XIII. Sloj mrke zemlje ispod intenzivne gari u kvadratima DE/III-IV (Plan 7)

Izdvaja se krčag kojeg često nalazimo kao prilog u grobovima na nekropolama, kako na Viminacijumu, tako i na ostalim u Meziji. Vrlo često javljaju se po tri krčaga istog tipa u grobovima spaljenih pokojnika i smatraju se lokalnim proizvodom. Obod ovih krčaga je neprofilisan i kratak, trbuh loptast ili ovalan i spušta se ka ravnom dnu profilisane ivice. Obod je često naglašen rebrom sa kojeg polazi drška koja se završava na ramenu. Rađen je od srednje prečišćene gline crvene boje pečenja, a površina je premazana crvenom bojom, boljeg ili slabijeg kvaliteta. Od pitosa u ovoj celini se javlja oblik sa horizontalno izvučenim užljebljenim obodom i kosim zidovima trbuha, rađen od srednje prečišćene gline sive boje pečenja i neobrađene spoljne površine. Oblik ognjišnog lonca koji se često nalazi na istraživanim lokacijama Viminacijuma, pa tako i ovde, je lonac prstenasto profilisanog oboda užljebljenog sa unutrašnje strane. Trbuh je loptast i spušta se ka ravnom nenaglašenom dnu. Može da ima jednu ili dve kratke trakaste, po sredini užljebljene drške. Trbuh je nekad ukrašen rebrima. Rađen je od peskovite gline sive boje pečenja i neobrađene površine.$^{63} \mathrm{Na}$ istraživanim lokacijama datuje se u drugu polovinu II i III vek. Pored ovog, često se javljaju još dva tipa lonca rađena od peskovite gline sive ili mrkosive boje pečenja i neobrađene spoljne površine. Jedan od njih je lonac koso razgrnutog, na ivici zadebljanog oboda, naglašenog vrata i jajolikog trbuha koji se spušta ka ravnom dnu, a drugi je veći lonac razgrnutog sa unutrašnje strane užljebljenog oboda i loptastog trbuha. Od trpezne keramike javlja se lončić sa jednom drškom užljebljenog oboda loptastog trbuha koji se spušta ka užem, prstenasto profilisanom dnu. Ovi lončići rađeni su od srednje prečišćene gline, crvene boje pečenja i spoljne površine premazane crvenom bojom. Javljaju se u nekoliko varijanti u zavisnosti od visine postavljenog trbuha.

63 Raičković 2007, T. VI/57. 
XIV. Sloj svetlo mrke ispod sloja sa gari u kvadratima DE/III-IV (Plan 7)

Još jedna zdela koja je rađena od žućkastobele kaolinske gline je tip dublje zdele (T. XVIII, slika 6) koso razgrnutog oboda sa blago zaobljenim iskošenim zidovima trbuha koji se spuštaju ka užem ravnom dnu. Od lonaca javlja se tip sa jako razgrnutim obodom, usko naglašenim vratom i jajolikim trbuhom koji se spušta ka ravnom dnu. Rađen je od peskovite gline sivomrke boje pečenja i nenaglašene spoljne ivice. U ovoj celini se u većem broju javljaju fragmenti tipova tanjira i pehara koji su već opisani.

XV. Svetlo mrka u kvadratima CD/III-IV dubina 1.60 - $2.30 \mathrm{~m}$ (Plan 7)

Svojim izgledom izdvaja se zdela tanjih zidova, razgrnutog oboda, naglašenog vrata i visoko postavljenog trbuha, rađena od dobro prečišćene gline beličaste boje i spoljne površine prevučene žućkastozelenkastom gleđu. Pretpostavlja se da je ova zdelica stigla kao import iz centralnogalskih radionica. Od ostalih tipova javlja se dublja zdela sa koso izvedenim, prstenasto profilisanim i užljebljenim obodom, visoko postavljenim trbuhom i blago udubljenim dnom. Rađena je od peskovite gline, mrke ili sive boje pečenja i neobrađene površine. ${ }^{64}$ Ponekad su na trbuhu izvedena rebra ili žljebovi. Po žljebu na obodu može se pretpostaviti da je mogla imati i odgovarajući poklopac. Javlja se na više lokacija na Viminacijumu gde se datuje u kraj II i prvu polovinu III veka. Paralele za ovaj tip imamo u Singidunumu. ${ }^{65}$ Isto tako, javlja se i široka zdela horizontalno razgrnutog i užljebljenog oboda sa rebrasto izvedenim trbuhom. Rađena je od peskovite gline žućkastobele, a ponekad i mrkosive boje pečenja i neobrađene spoljne površine. ${ }^{66}$ Poklopci su zastupljeni tipom neprofilisanog oboda i kosih, narebrenih zidova trbuha koji se završavaju dugmetastom drškom. Rađen je od peskovite gline sive boje pečenja i neobrađene spoljne površine (T. XIX, slika 30).

XVI. Sloj mrkožute ispod sloja crveno zapečene zemlje u kvadratima ED/II, CDE/III dubina $1.10-3.10 \mathrm{~m}$ (Plan 7)

Sloj je datovan novčićem I veka (Vespazi-

64 Raičković 2007, T. III/38.

65 Nikolić-Đorđević 2000, 42, tip I/57.

66 Raičković 2007, T. IV/42. jan, 69-79 n. e.). U njemu se kao najzanimljivija izdvaja minijaturna posuda sa drškom, rađena od srednje prečišćene gline crvene boje pečenja i spoljne površine premazane crvenom bojom. Javljaju se i dublje zdele iskošenog, sa unutrašnje strane užljebljenog oboda i visoko postavljenog trbuha koji se spušta ka užem nenaglašenom ravnom dnu. Ove zdele rađene su od peskovite gline sive boje pečenja i neobrađene spoljne površine. Ponekad je trbuh narebren.

\section{KERAMIKA ŽIŠCI I KERAMIČKI TEG (T. XII, XIII, XIV, XV/ 120-153)}

Po brojnosti posle keramičkih posuda slede žišci. To ne iznenađuje ako se ima u vidu da su oni korišćeni ne samo za osvetljavanje privatnih kuća, javnih zgrada i hramova, nego su i stavljani u grobove kao prilozi. Najčešće ih nalazimo fragmentovane, ali ipak dovoljno očuvane da se mogu tipski odrediti. Najbrojniji su žišci tipa firma lampe (T. XIV, slika 142, T. XV, slike 148, 150) sa pečatima radionica koje su potvrđene na ovom lokalitetu. Sačuvana dna u nekoliko slučajeva nose pečate majstora (T. XIII, slike 133 i 137, T. XIV, slike 145 i 146, T. XV, slika 150) izvedeni u reljefu. Žišci sa pečatom FESTI (T. XIV, slika 145) pripadaju majstoru koji je proizvodio sve tipove firma lampi i one se javljaju od druge polovine I veka do kraja II, pa i tokom III veka. Pečat FORTIS (T. XIV, slika 146) se najviše javlja ne samo na Viminacijumu već i na drugim istraživanim lokalitetima na prostoru Gornje Mezije i sreće se od kraja I pa kroz II i III sve do IV veka. Pečat CASSI se na Viminacijumu javlja i traje tokom III veka. Ove lampe su kružnog oblika tela sa izduženim kljunom koji je na vrhu zaobljen. Disk je ravan, najčešće neukrašen, sa otvorom na sredini. Diskovi žižaka drugih tipova su bili različito ornamentisani (palmeta, rozeta, koncentrični krugovi i sl). Drške žižaka su uglavnom sa kružnom perforacijom, a nekad su izvedene i u obliku lista (T. XIII, slika 140). Samo jedan od pronađenih žižaka je sa tri plamenika (T. XIV, slika 144), dok su ostali sa jednim. Svetiljka je pravougaonog oblika, sa jedne strane su tri otvora za fitilje, a na drugoj listolika drška. Disk je plastičnim trakama podeljen na dva polja u kojima se nalazi po jedan 
otvor. Listolika drška je šuplja, dekorisana i koso postavljena. Dno je ravno. Poreklo ovih svetiljki vezuje se za Egipat, a na prostoru Gornje Mezije javljaju se od početka II veka. ${ }^{67}$ Jedan od ređih oblika je žižak sa konkavnim diskom, zaobljenim ramenima i širim otvorom za ulje u centru (T. XIV, slika 143). Otvor za fitilj je manji, a trakasta drška je pomerena do sredine diska. Dno je ravno. Svi ovde otkriveni žišci spadaju u proizvode lokalne radionice koja je na Viminacijumu i potvrđena. Pored žižaka od keramičkog materijala nađen je i jedan keramički teg (T. XV, slika 153).

- Slika broj 120/ C:1081, dva fragmentovana žiška. Fragment diska i ramena žiška rađenog od srednje prečišćene gline oker boje pečenja.

- Slika broj 121/ C:1082, fragmentovani žižak. Fragment diska i ramena žiška izrađenog od srednje prečišćene gline braon boje pečenja i crveno bojene površine.

- Slika broj 122/ C:1109, fragmenti dva keramička žiška. Fragment recipijenta i dna žiška grube fakture crvene boje pečenja i crveno bojene površine.

- Slika broj 123/ C:1115, dva fragmenta keramičkog žiška. Fragmenti recipijent, dna i diska žišska izrađenog od srednje prečišćene gline crvene boje pečenja i crveno bojene površine. Na disku je figuralna predstava.

- Slika broj 124/ C:1133, dva fragmentovana žiška. Fragment diska žiška izrađenog od srednje prečišćene gline crvene boje pečenja sa premazom firnisa mrke boje. Na disku ornament - rozeta.

- Slika broj 125/ C:1110, fragmenti dva keramička žiška. Fragment recipijenta i dna žiška rađenog od srednje prečišćene gline crvene boje pečenja i glačane površine

- Slika broj 126/ C:1132, dva fragmentovana žiška. Fragment recipijenta i dna žiška izrađenog od srednje prečišćene gline crvene boje pečenja i crveno bojene površine.

- Slika broj 127/ C:1048, keramiči žižak. Fragment kljuna, ramena i diska žiška izrađenog od srednje prečišćene gline crvene boje pečenja i crveno bojene površine.

- Slika broj 128/ C:1105, deo žiška. Fragment diska i ramena žiška izrađeni su od srednje pre-

67 Krunić 2005, Tip XII. čišćene gline crvene boje pečenja i crveno bojene površine.

- Slika broj 129/ C:1119, fragmentogani keramički žižak. Fragmenti kljuna, recipijenta i dna diska izrađenog od srednje prečišćene gline crvene boje pečenja i crveno bojene površine.

- Slika broj 130/ C:1080, fragmenat keramičkog žiška. Fragment diska i ramena žiška sa trakastom drškom koja ima tri žljeba. Izrađen je od srednje prečišćene gline crvene boje pečenja.

- Slika broj 131/ C:1188, listolika drška žiška. Fragment ornamentisane drške crveno pečenog i crveno bojenog žiška.

- Slika broj 132/ C:1143, fragment keramičkog žiška. Fragment ramena žiška izrađenog od srednje prečišćene gline crvene boje pečenja i crveno bojene površine.

- Slika broj 133/ C:1040, fragmentovana dva keramička žiška. Fragment dna i recipijenta žiška izrađenog od srednje prečišćene gline crvene boje pečenja sa pečatom majstora na dnu od koga je očuvano samo F.....

- Slika broj 134/ C:1204, deo žiška tipa „firma lampe“. Fragment žiška izrađen od dobro prečišćene zemlje crvene boje pečenja i crveno bojene površine.

- Slika broj 135/ C:1162, fragmentovan žižak. Fragmenti drške, diska i recipijenta žiška izrađenog od srednje prečišćene gline crvene boje pečenja i braon bojene površine.

- Slika broj 136/ C:1227, fragment listolike drške, diska, recipijenta i dna žiška rađenog od dobro prečišćene zemlje crvene boje pečenja. Površina je premazana firnisom braon boje.

- Slika broj 137/ C:1194, fragment žiška sa pečatom u trostrukom koncentričnom krugu. Žižak je rađen od fino prečišćene gline crvene boje pečenja sa premazom crvenog firnisa. $\mathrm{Na}$ dnu pečat FORTIS.

- Slika broj 138/ C:1238, deo žiška. Fragment diska žiška izrađenog od srednje prečišćene gline crvene boje pečenja i crveno bojene površine.

- Slika broj 139/ C:1211, fragment žiška. Fragment kljuna i recipijenta žiška rađenog od srednje prečišćene gline crvene boje pečenja i crveno bojene površine.

- Slika broj 140/ C:1259, drška žiška listolikog oblika.

- Slika broj 141/ C:1164, ceo žižak, izrađen od srednje prečišćene gline crvene boje pečenja sa 
premazom firnisa mrke boje.

- Slika broj 142/ C:1137, fragmentovani žižak. Fragment kljuna, ramena i recipijenta žiška izrađenog srednje prečišćene gline, crvene boje pečenja i crveno bojene površine.

- Slika broj 143/ C:1163, ceo žižak. Izrađen je od srednje prečišćene gline crvene boje pečenja i crveno bojene površine. Trakasta drška sa dva žljeba je postavljena ekscentrično u odnosu na uzdignut kljun žiška.

- Slika broj 144/ C:1217, pravougaoni žižak sa tri plamenika. Izrađen je od dobro prečišćene gline, crvene boje pečenja i crveno bojene površine. Ima trougaonu dršku ukrašenu zarezima.

- Slika broj 145/ C:1208, deo žižka tipa „firma lampe" sa pečatom ...TI na dnu. Fragmenti recipijenta i dna žiška izrađeni su od fino prečišćene gline crvene boje pečenja i crveno bojene površine. Na dnu pečat (FES)TI. (?)

- Slika broj 146/ C:1214, manji žižak kojem nedostaje kljun i disk tipa „firma lampa“ sa pečatom na dnu. Fragmentovan žižak izrađen je od fino prečišćene gline, crvene boje pečenja i crveno bojene površine. Na dnu pečat FORTIS.

- Slika broj 147/ C:1039, fragmentovana dva keramička žiška, rađeni od srednje prečišćene gline crvene boje pečenja i crveno bojene površine sa ornamentisanom drškom i lažnom volutom.

- Slika broj 148/ C:1264, žižak tipa „firma lampa" kome nedostaje dno. Fragmentovani žižak izrađen od dobro prečišćene zemlje crvene boje pečenja.

- Slika broj 149/ C:1276, ceo žižak. Žižak je izrađen od dobro prečišćene zemlje crvene boje pečenja i crveno bojene površine.

- Slika broj 150/C:1044, žižak izrađen od srednje prečišćene gline crvene boje pečenja i crveno bojene površine sa pečatom majstora na dnu CASSI.

- Slika broj 151/ C:1290, žižak, izrađen od dobro prečišćene gline crvene boje pečenja i crveno bojene površine. Disk je ukrašen motivom u obliku rozete, a plastičnim bobicama na ramenu.

- Slika broj 152/ C:1270, žižak kojem nedostaje kljun.

- Slika broj 153/ C:1049, keramiči teg. Teg je prizmatičnog oblika izrađen od gline sa primesama peska i tucane školjke mrke boje pečenja.

\section{STAKLO \\ (T: I, II / 1-15)}

Stakleni nalazi se mogu razvrstati u nekoliko podgrupa među kojima bi najbrojnija bila ona koju čine čaše i pehari ukrašeni tehnikom brušenja ili horizontalnim rebrima. U nešto manjem broju javljaju se i zdele. Potom slede ukrašena dna boca, drška posude i jedan žeton od staklene paste. Nalaženi su i fragmenti ravnog prozorskog stakla. Predmeti od stakla ukazuju na italsko galski import, jer se radi o formama koje podsećaju na oblike terra sigillata posuda i rađene su od stakla beličaste boje. Ukrašavanje brušenjem i urezivanjem je tehnika koja svoj vrhunac dostiže tokom III veka (T. I, slike 1, 2, 3), najviše na zdelama blago profilisanog, ravno završenog oboda, dubljeg hemisferičnog recipijenta i ravnog ili blago udubljenog dna. Izrađene su tehnikom slobodnog duvanja i datuju se u period od II do IV veka. ${ }^{68}$ Potom slede zdele (T. I, slike 6 i 9) koso razgrnutog, pri vrhu prelomljenog oboda, koničnog recipijenta i visoke prstenaste stope. Izrađene su tehnikom duvanja u kalup. Mogu biti (T. I, Slika 6) dekorisane brušenim ornamentom. Datuju se u period od II do IV veka. ${ }^{69}$ Zdela blago iskošenog (T. I, slika 4) sa spoljne strane narebrenog oboda, dubljeg hemisferičnog recipijenta i ravnog ili udubljenog dna, izrađena je tehnikom slobodnog duvanja i ukrašena plastično izvedenim rebrima po sredini trbuha. ${ }^{70}$ Javlja se i pehar (T. I, slika 7) razgnutog, prstenasto zadebljanog oboda, sferičnog recipijenta i prstenaste stope. Izrađen je tehnikom slobodnog duvanja, a vrat je ukrašen tankim horizontalnim plastičnim rebrom. Datuje se u kraj I i u II vek. ${ }^{71}$ Javlja se i plići pehar (T. I, slika 8) cilindričnog recipijenta sa prstenasto zadebljanim punim obodom i prstenastom stopom. Izrađen je tehnikom slobodnog duvanja i datuje se u II-III vek. ${ }^{72}$ Od boca koje obično imaju horizontalno razgrnut obod, kratak cilindrični vrat i izdužen prizmatični recipijent, očuvani su samo fragmenti ravnog dna ukrašenog reljefnim koncentričnim krugovima (T. II, slika 11). Ove boce mogu imati i jednu dršku, a rađene su tehnikom duvanja u ka-

68 Ružić 1994, T. XXV/5 - 10.

69 Ružić 1994, T. XXIV/8, 10.

70 Ružić 1994, T. XXV/12.

71 Ružić 1994, T. XXIX/10.

72 Ružić 1994, T. XXX/8. 
lup. Javljaju se od I pa sve do IV veka. ${ }^{73}$

- Slika broj 1 / C: 1199, delovi čaše ukrašene brušenim ornamentom.

- Slika broj 2/ C: 1237, fragmentovana posuda, ukrašena tehnikom brušenja.

- Slika broj 3/ C: 1221, fragmeni oboda i trbuha čaše koji su ukrašeni brušenjem.

- Slika broj 4/ C: 1218, delovi oboda pehara ukrašenog horizontalnim rebrima.

- Sl br. 5/ C: 1247, obod posude od mlečnobelog stakla.

- Slika broj 6/ C: 1235, deo zdele od mlečnobelog stakla ukrašen tehnikom brušenja.

- Slika broj 7/ C: 1288, dva fragmenta oboda pehara. Obod je prstenasto profilisan, a na ramenu posude je jedno plastično rebro.

- Slika broj 8/ C: 1213, deo razgrnutog oboda i trbuha posude.

- Slika broj 9/ C: 1285, fragmenti koso razgrnutog i prstenasto profilisanog oboda zdele.

- Slika broj 10/ C: 1171, deo dna posude reljefno ukrašen.

- Slika broj 11/ C: 1176, reljefno ukrašeno dno boce, pravougaonog oblika na čijem su dnu dva koncentrična kruga.

- Slika broj 12/C: 1245, reljefno ukrašeno dno boce.

- Slika broj 13/ C: 1187, deo trbuha posude ukrašene tehnikom brušenja.

- Slika broj 14/ C: 1254, narebrena drška posude od plavičastog stakla.

- Slika broj 15/ C: 1099, žeton od staklene paste.

\section{OLOVO \\ (T. III/16 - 21)}

Od šest pronađenih nalaza načinjenih od olova samo je polovinu bilo moguće i definisati. Tu spadaju olovni teg, cevčica i elipsoidni poklopac. Ostali nalazi zbog svoje deformisanosti ostaju neprepoznati.

- Slika broj 16/ C:1168, deo predmeta koji se ljuspa.

- Slika broj 17/ C:1129, fragmentovani predmet.

- Slika broj 18/ C:1246, predmet.

73 Ružić 1994, T. II/1.
- Slika broj 19/ C:1061, teg u obliku kugle (teg ili projektil).

- Slika broj 20/ C:1125, cevčica dužine $6,5 \mathrm{~cm}$ i širine $2 \mathrm{~cm}$.

- Slika broj 21/ C:1124, poklopac elipsoidnog oblika, dimenzija: 6,4 x 7,2 cm.

\section{SREBRO (T. III/ 22)}

Srebrni materijal zastupljen je sa samo jednim nalazom. Radi se o pločastom delu nekog srebrnog predmeta čiju bližu namenu nije moguće odrediti.

- Slika broj 22/ C:1260, pločasti deo predmeta četvorougaonog oblika.

\section{KAMEN \\ (T. IV, V/ 23-33)}

Kameni nalazi zastupljeni su sa 11 predmeta. Najbrojniji su fragmenti kamenih posuda i to obodi i dna tanjira. Rađeni su od kamena u raznim bojama i uglačane površine. Pored posuda nađeni su i jedan kalup sa izlivnikom, kameni tučkovi i projektili. U ovu grupu spada i jedna perla od krečnjaka.

- Slika broj 23/ C:1050, fragment tanjira, horizontalno razgrnutog oboda $i$ trbuha posude od belog mermera.

- Slika broj 24/ C:1157, komad pločice od tankog belog mermera.

- Slika broj 25/ C:1041, fragment neprofilisanog oboda posude od belosivog mermera.

- Slika broj 26/ C:1100, deo žrvnja rađen od sivkastog kamena.

- Slika broj 27/ C:1269, projektil.

- Slika broj 28/ C:1263, polovina loptastog predmeta od mermera.

- Slika broj 29/ C:1158, deo predmeta od kamena peščara, žućkaste boje kružnog preseka (verovatno tučak).

- Slika broj 30/ C:1121, ceo, ornamentisan, tučak od beličastog kamena u vidu falusa.

- Slika broj 31/ C:1074, polovina kalupa od kamena zelene boje čiji je prostor za livenje polu- 
kalotastog oblika sa izlivnikom, a na dva ugla nalaze se udubljenja za pričvršćivanje drugog dela kalupa.

- Slika broj 32/ C:1234, manji obrađen kamen, pravougaonog oblika sa žljebom.

- Slika broj 33/ C:1280, kružna perla od krečnjaka.

\section{BRONZA (T. VI, VII, VIII/ 34-85)}

Predmeti od bronze su najraznovrsniji. Iako su nitne najbrojnije i kod njih ima razlike kako u veličini, tako i u obliku glave (ravna ili loptasta, pravougaona ili okrugla) i dužini usadnika i obliku njegovog preseka. Potom slede igle, (šivaće i toaletne), stilusi, jedna bronzana fibula (T. VI, sl. $34)^{74}$ koja se datuje u period III, možda početak IV veka, a od pojasnih pređica samo jezičci (T. VI, sl. 37, 38, 39). Zanimljiva je igla (T. VI, sl. 40) sa glavom u obliku tri male dvosekle sekire. Bronzane igle (T. VI, sl. 41 i 45) se nalaze kao prilog u grobovima sa inhumiranim pokojnicima koji su datovani novcem II veka. ${ }^{75}$ Nitne i delovi oplate (T. VIII) nalaze se i u naseobinskim slojevima kao i u nekropolama. ${ }^{76}$ Pojava bronzanih ključeva (T. VII, slika 59) mogla bi da ukaže na činjenicu da se ovde radi o žrtvenom sloju, jer se ključevi ređe nalaze u grobovima. Takvi ključevi su, po tradiciji, prilikom daća polagani u grobove zbog uspostavljanja veze između doma živih i večnog boravišta umrlog. Delovi lanca (T. VII, slika 64) upotpunjuju asortiman nalaza od bronze, dok dosta oštećenih predmeta ne može biti prepoznato i opredeljeno po funkciji. Sav nađeni novac na ovom prostoru je bronzani.

- Slika broj 34/ C:1042, lučna fibula, kojoj nedostaje igla.

- Slika broj 35/ C:1170, deo fibule.

- Slika broj 36/ C:1141, okov leptirastog oblika sa dva očuvana zakivka.

- Slika broj 37/ C:1210, trn.

- Slika broj 38/ C:1207, pojasni jezičak.

- Slika broj 39/ C:1175, trn pređice, izrađen od žice pravougaonog preseka.

74 Petrović 1997, str. 154, sl. 248.

75 Zotović, Jordović 1990, T. XXVI/6.

76 Zotović, Jordović 1990, T. CIX/6, 7.
- Slika broj 40/ C:1056, igla, dužine $8.5 \mathrm{~cm}$, na koju su nanizana u jednom delu dva bronzana priveska dužine $3 \mathrm{~cm}$. Igla sa dve minijaturne sekire (čekić) kao glave igle.

- Slika broj 41/ C:1123, cela šivaća igla sa elipsoidnom ušicom kružnog preseka.

- Slika broj 42/ C:1203, predmet.

- Slika broj 43/ C:1239, igla, moguće od fibule, sa spiralno namotanom glavom.

- Slika broj 44/ C:1160, fragmentovano stilo.

- Slika broj 45/ C:1205, igla.

- Slika broj 46/ C:1243, stilo, instrument trouglaste, pločaste glave sa telom kvadratnog preseka.

- Slika broj 47/ C:1196, 12 nitni.

- Slika broj 48/ C:1181, deo predmeta sa punom loptastom glavom. Predmet koji čini bronzana kuglica sa fragmentom alkice četvorougaonog preseka.

- Slika broj 49/ C:1283, nitna kružne pločaste glave i usadnika pravougaonog preseka.

- Slika broj 50/ C:1266, fragmentovano dugme.

- Slika broj 51/ C:1289, nitna.

- Slika broj 52/ C:1293, nitna.

- Slika broj 53/ C:1228, predmet, najverovatnije nitna.

- Slika broj 54/ C:1230, nitna.

- Slika broj 55/ C:1202, nitna.

- Slika broj 56/ C:1284, nitna sa manjom kružnom glavom.

- Slika broj 57/ C:1224, fragmentovan ključ prstenaste glave i trapezastog tela.

- Slika broj 58/ C:1201, deo predmeta.

- Slika broj 59/ C:1223, fragmentovani ključ prstenaste glave i trapezastog tela.

- Slika broj 60/ C:1038, privezak - kapsula, kapljičastog oblika, ukrašena plavim, žutim i belim emajlom.

- Slika broj 61/ C:1183, nedefinisani predmet profilisane drške sa perforacijom na jednom kraju dok je telo predmeta fragmentovano.

- Slika broj 62/ C:1165, privezak trakastog oblika.

- Slika broj 63/ C:1268, deo predmeta.

- Slika broj 64/ C:1192, fragmentovan lančić. Karike se sastoje od alki u obliku osmica.

- Slika broj 65/ C:1258, deo žice.

- Slika broj 66/ C:1256, drška.

- Slika broj 67/ C:1173, predmet sa vrhom u obliku kukice. 
- Slika broj 68/ C:1198, deo oplate od lima.

- Slika broj 69/ C:1272, dugme.

- Slika broj 70/ C:1231, tri pločice - deo oklopa, dve cele i jedna fragmentovana.

- Slika broj 71/ C:1287, fragment predmeta.

- Slika broj 72/ C: 1277, fragmentovani predmet.

- Slika broj 73/ C:1075, kružna aplikacija, od tankog lima, sa perforacijom na sredini i nazubljenih ivica.

- Slika broj 74/ C:1222, deo oplate od tankog lima.

- Slika broj 75/ C:1126, fragmentovana pločica, u vidu jezička, dužine oko $5 \mathrm{~cm}$, sa pet delova koji se spajaju. Verovatno se radi o fragmentima oplate od debljeg lima.

- Slika broj 76/ C:1226, deo predmeta - presavijeni lim sa perforacijom kružnog oblika.

- Slika broj 77/ C:1265, deformisana kružna aplikacija od tankog lima nazubljene ivice. Ukrašena je urezanim koncentričnim krugovima.

- Slika broj 78/ C:1286, fragmentovana oplata od tankog lima pravougaonog oblika sa dve kružne perforacije.

- Slika broj 79/ C:1180, fragmenti oplate od tankog lima ukrašeni iskucavanjem.

- Slika broj 80/ C:1253, deo pojasne oplate.

- Slika broj 81/ C:1279, alka.

- Slika broj 82/ C:1195, alka, moguće je da se radi o prstenu.

- Slika broj 83/ C:1159, alka.

- Slika broj 84/ C:1261, predmet.

- Slika broj 85/ C:1240, deo predmeta.

\section{GVOŽĐE}

\section{(T. IX, X, XI/ 86-119)}

Gvozdeni nalazi su loše očuvani i korodirani. Teško im je odrediti prvobitne funkcije, a problem predstavlja i njihovo datovanje jer pojedini oblici bez promena traju do srednjeg veka. Pored klinova koje ovde nismo predstavili, od gvožđa su alke, delovi lanaca, fragmentovani noževi, nitne, ključevi, kao i veći broj predmeta koji nisu prepoznati i opredeljeni. Izdvaja se fibula (T. IX, slika 86) sa posuvraćenom stopom. Ovakve fibule datuju se u III vek. Od nalaza koji spadaju u grupu za pridržavanje odeće, oružja i opreme izdvajaju se i ostaci kružne pređice sa sačuvanim trnom (T. IX, slika 88) i samo delimično očuvana pravougaona pređica (T. IX, slika 89). Za bušenje drveta koristilo se svrdlo ili terebra (T. X, slika 108). Ova svrdla mogu biti šiljata, kašikasta i spiralna. Teško se mogu identifikovati i razlikovati od turpija ili šila. Kašikasta svrdla se nalaze kako u civilnim naseljima tako i u vojnim logorima. Sastoje se od sečiva kašikastog oblika i drške koja se završava trapezoidno, trouglasto ili piramidalno. ${ }^{77}$ Dleto ili scalprum (T. X, slika 98) je alat koji ima širok spektar funkcija, uglavnom u obradi drveta, kamena i metala. Mogu biti namenjeni za probijanje, dubljenje ili za pravljenje uglova. Uglavnom su bez drvene ili koštane drške, a primerci sa usadnikom korišćeni su isključivo za obradu drveta. ${ }^{78} \mathrm{Za}$ ovde pronađene gvozdene alatke (T. X, slike 97, 101, 107) pretpostavljamo da su služile za obradu drveta. ${ }^{79}$ Pronađene šunegle su različitih veličina, dužine trna, a glava im je šuplja i kupastog oblika. Alke i fragmenti lanca se ne mogu uže datovati. Gvozdeni ključevi (T. XI, slike 112 i 113) na drugim lokacijama Viminacijuma nalaženi su kao prilog u grobovima gde su najranije datovani novcem II veka. ${ }^{80}$

- Slika broj 86/ C:1076, fragmentovani predmet, kvadratnog preseka i lučno savijen.

- Slika broj 87/ C:116, fragmentovana fibula.

- Slika broj 88/ C:1145, pređica (kružna gvozdena kopča sa očuvanim trnom).

- Slika broj 89/ C:1136, fragmentovana pređica.

- Slika broj 90/ C:1292, veća fragmentovana alka.

- Slika broj 91/ C:1291, manja cela alka.

- Slika broj 92/ C:1271, veći deo alke.

- Slika broj 93/ C:1092, žica modelovana kao drška.

- Slika broj 94/ C:1169, deo korodiranog lanca koji čine karike u obliku osmica.

- Slika broj 95/ C:1250, alka od žice kružnog preseka.

- Slika broj 96/ C:1229, alka.

- Slika broj 97/ C:1101, fragmentovani predmet. Alatka pod jakim slojem korozije.

- Slika broj 98/C:1166, deo alatke sa usadnikom.

- Slika broj 99/ C:1130, oštećeni korodirani predmet, možda alatka.

77 Popović 1988, T. XXII/5.

78 Popović 1988, T. XXXVI/3.

79 Popović 1988, str. 226 sl. 32 i str. 227 sl. 33

80 Zotović, Jordović 1990, XXVI/13. 
- Slika broj 100/ C:1138, nož sa usadnikom.

- Slika broj 101/ C:1216, deo alatke sa usadnikom.

- Slika broj 102/ C:1106, predmet.

- Slika broj 103/ C:1278, fragmentovano sečivo kojem nedostaje usadnik.

- Slika broj 104/ C:1274, predmet nepoznate namene.

- Slika broj 105/ C:1112, nož sa usadnikom za dršku.

- Slika broj 106/ C:1085, i predmet trougaonog oblika pod jakim slojem korozije, dimenzija $9,8 \times 4,2 \mathrm{~cm}$.

- Slika broj 107/ C:1074, predmet nepoznate namene.

- Slika broj 108/ C:1062, svrdlo.

- Slika broj 109/ C:1249, fragment oplate od debljeg lima sa kružnom perforacijom.

- Slika broj 110/ C:1197, predmet od debljeg lima savijenog u cev.

- Slika broj 111/ C:1117, deformisana drška izrađena od žice kvadratnog preseka.

- Slika broj 112/ C:1209, ključ.

- Slika broj 113/ C:1193, ključ.

- Slika broj 114/ C:1140, fragmentovani predmet nepoznate namene.

- Slika broj 115/ C:1244, predmet kvadratnog preseka i prstenaste glave.

- Slika broj 116/ C:1083, fragmentovani predmet, deo lanca, gvozdena klanfa.

- Slika broj 117/ C:1215, dve šunegle.

- Slika broj 118/ C:1102, 11 komada šunegli.

- Slika broj 119/ C:1275, zakivak.

\section{KOST \\ (T. XVI, XVII/ 154-211)}

Predmeti od kosti spadaju u najbrojniju, ali ne i najraznovrsniju grupu. Preovlađuju igle i to u podjednakom odnosu ukrasne igle za kosu i šivaće igle. Nađene igle su često fragmentovane pa se ne može uvek sa sigurnošću odrediti o kojoj vrsti igala se radi. Ukrasne igle su najčešće okruglog ili valjkastog preseka sa ravnom ili piramidalnom glavom, ređe sa loptastom ili posebno ukrašenom (T. XVI, slike 161, 162, 181). Kod igala koje su imale funkciju ukosnica, glava je uglavnom polukružna, a telo ima kružni presek. Takve igle na teritoriji Gornje Mezije nalažene su u slojevima od
I do IV veka. ${ }^{81}$ Kod šivaćih igala presek je kružan ili elipsoidan, a perforacija je valjkastog, ${ }^{82}$ kružnog ili oblika osmice. Glava igle se najčešće oblo završava mada ima primeraka gde je i glava šivaće igre dekorisana (T. XVII, slika 203). Ovako brojne koštane igle mogle bi da ukažu na običaj da su se nad grobovima pokojnika u toku daće koštane igle koristile za izvlačenje dogorelih fitilja u žišcima. Pošto su namerno lomljene, spajaju se na mestu starih preloma. Od ostalih koštanih nalaza izdajaju se zupci češlja, koštani žeton za igru i dve koštane kockice (T. XVII, slika 206 i 211). Koštani žetoni (XVII, slika 208) za igru na Viminacijumu se nalaze u spaljenim grobovima datovanim još u I vek, ${ }^{83}$ a koštani češljevi (T. XVII, slika 207) na istom prostoru se javljaju u grobovima sa inhumacijom od početka II veka. ${ }^{84}$

- Slika broj 154/ C:1055, fragmentovana igla.

- Slika broj 155/ C:1057, dve igle, jedna cela i jedna fragmentovana.

- Slika broj 156/ C:1058, dve igle, jedna fragmentovana i jedna cela.

- Slika broj 157/ C:1059, dve fragmentovane igle

- Slika broj 158/ C:1063, cela igla.

- Slika broj 159/ C:1060, dve fragmentovane igle

- Slika broj 160/ C:1064, cela igla.

- Slika broj 161/ C:1065, cela igla.

- Slika broj 162/ C:1066, fragmentovana igla.

- Slika broj 163/ C:1070, igla.

- Slika broj 164/ C:1084, fragmentovana igla.

- Slika broj 165/ C:1108, deo igle.

- Slika broj 166/ C:1113, fragmentovana igla.

- Slika broj 167/ C:1114, fragmentovana igla.

- Slika broj 168/ C:1116, fragmentovana igla.

- Slika broj 169/ C:1118, fragmentovana igla.

- Slika broj 170/ C:1120, u celosti očuvana igla kupasto profilisane glave.

- Slika broj 171/ C:1122, fragmentovana igla.

- Slika broj 172/ C:1128, fragmentovana igla.

- Slika broj 173/ C:1135, fragmentovana igla iz dva dela koji se ne spajaju.

- Slika broj 174/ C:1131, cela igla, ukosnica, sa zaravnjenom glavom kružnog preseka.

- Slika broj 175/ C:1142, igla, ukosnica, piramidalne glave i kružnog preseka.

81 Petković 1995, tip IV- 30.

82 Zotović, Jordović 1990, XX/9.

83 Zotović, Jordović 1990, T.LXX/7.

84 Zotović, Jordović 1990, T. XXXII/13. 
- Slika broj 176/ C:1144, igla.

- Slika broj 177/ C:1146, cela igla.

- Slika broj 178/ C:1167, deo igle.

- Slika broj 179/ C:1178, dve igle, prva je sa kupasto profilisanom glavom.

- Slika broj 180/ C:1179, dve igle, od kojih je druga sa ravno završenom glavom.

- Slika broj 181/ C:1185, igla.

- Slika broj 182/ C:1206, šivaća igla.

- Slika broj 183/ C:1172, cela igla.

- Slika broj 184/ C:1186, šivaća igla.

- Slika broj 185/ C:1242, deo igle za šivenje.

- Slika broj 186/ C:1255, igla kojoj nedostaje glava.

- Slika broj 187/ C:1190, igla - ukosnica.

- Slika broj 188/ C:1220, deo igle kupaste glave.

- Slika broj 189/ C:1191, šivaća igla.

- Slika broj 190/ C:1200, u celosti očuvana igla kupasto profilisane glave.

- Slika broj 191/ C:1139, fragmentovana igla.

- Slika broj 192/ C:1127, fragmentovana igla za šivenje sa dve ušice - jednom kružnom i drugom u obliku osmice.

- Slika broj 193/ C:1252, igla za šivenje, kojoj nedostaje vrh.

- Slika broj 194/ C:1156, igla sa loptastom glavom.

- Slika broj 195/ C:1225, šivaća igla kojoj nedostaje vrh.

- Slika broj 196/ C:1189, šivaća igla.

- Slika broj 197/ C:1232, fragentovana igla za šivenje.

- Slika broj 198/ C:1233, fragmentovana igla za šivanje.

- Slika broj 199/ C:1251, igla za šivenje kojoj nedostaje glava.

- Slika broj 200/ C:1273, igla - ukosnica, kojoj nedostaje deo glave.

- Slika broj 201/ C:1281, dve šivaće igle.

- Slika broj 202/ C:1248, gornji deo šivaće igle.

- Slika broj 203/ C:1236, u celosti sačuvana igla sa ornametnisanom glavom.

- Slika broj 204/ C:1282, dve šivaće igle.

- Slika broj 205/ C:1103, poluobrađena kost kvadratnog preseka.

- Slika broj 206/ C:1219, kockica nepravilnog oblika.

- Slika broj 207/ C:1262, deo češlja, zupci.

- Slika broj 208/C:1107, kružni žeton sa jednom ravnom, a drugom konkavnom stranom.
- Slika broj 209/ C:1212, deo predmeta od kosti ukrašene površine - oplata, najverovatnije od drške.

- Slika broj 210/ C:1134, fragmentovana igla za kosu, ornamentisana kosim urezima,

- sa prstenastom glavom.

- Slika broj 211/ C:1241, kockica za igru nepravilnog oblika tipa tessera.

\section{ZAKLJUČAK}

Tokom istaživanja prostora Sonde 29 otkriveno je 16.836 fragmenata keramičkih posuda. Oni su obrađeni i razvrstani po oblicima posuda i to u deset grupa. Najraznovrsniju grupu po oblicima predstavljaju zdele sa 64 tipa, za njima slede lonci koji se javljaju u 39 tipova, dok su iznenađujuće raznovrsni i brojni tanjiri zastupljeni sa 23 tipa. Iako brojčano najdominantniji, fragmenti amfora u tipovima su mnogo skromniji, pa se može izdvojiti deset. Fragmenti poklopaca koji su hronološki najmanje osetljivi mogu se razvrstati u 20 tipova, pitosi u svega četiri, kao i krčazi, kadionice u pet, a pehari u 12.

Većina posuda predstavlja proizvode lokalnih radionica, mada se javljaju i importni primerci odnosno zdele rađene $u$ tehnici tera sigilate. Najbrojniju grupu čine posude koje su korišćene u svakodnevnom životu, za serviranje i konzumiranje hrane, tako da preovlađuju zdele i lonci, a zatim tanjiri, dok se ostale forme, krčazi i kadionice javljaju u znatno manjem broju. To su posude rađene od srednje prečišćene gline crvene boje pečenje, čija je površina bojena u sličnim tonovima ili, znatno ređe, neobrađena. Najzastupljenije su zdele kalotastog recipijenta, prstenasto profilisanog oboda i stope, za čiji oblik bliske analogije nalazimo na lokalitetima Gornje Mezije i Panonije. Brojne su i zdele tzv. ,patka tipa”, prstenasto profilisanog oboda, sa plastično izvedenom trakom na trbuhu, među kojima ima primeraka sa firnisovanom spoljnom površinom. Ovaj tip se u više varijanti javlja kroz duži vremenski period. Brojne su i pliće zdele zaobljenog i povijenog na unutrašnju stranu uvučenog zadebljanog oboda i ravnog dna. Ove zdele su česte na Viminacijumu i javljaju se u različitim dimenzijama.

Brojni su i lonci sa dve drške, horizontalno ili koso razgrnutog oboda, cilindričnog vrata $i$ 
loptastog trbuha, na nisko profilisanoj stopi, koji se, kao i prethodno navedene zdele, u sličnim varijantama profilacije javljaju kroz duži vremenski period, od II do početka IV veka.

Tanjiri čine sledeću formu po brojnosti, a pre svih to je forma tanjira razgrnutog i na spoljnu stranu izvijenog oboda, profilisanog zida koji se lomi i koso povija prema prstenastom dnu. Rađeni su od srednje prečišćene gline crvene boje pečenja, a površina im je bojena tonovima crvene boje.

Drugoj grupi posuda, koja se javlja u znatno većem broju od prethodne, pripadaju posude u kojima je pripremana hrana. Većinu čine lonci i zdele rađeni od gline peskovite fakture, crvene ili sive boje pečenja, najčešće neobrađene spoljne površine. Među njima, zbog brojnosti, treba izdvojiti lonce sa jednom, ili dve drške, užljebljenog oboda, rebrasto profilisanog trbuha i užeg ravnog dna, a koji su rađeni od beličaste peskovite gline. I ovo je jedan od tipova koji se, sa manjim promenama u profilaciji, javlja u dužem vremenskom periodu od II do IV veka. Od iste vrste gline rađene su i zdele horizontalno razgrnutog, užljebljenog oboda, blago ukošenih zidova trbuha koje se spuštaju ka širokom ravnom dnu.

Importne posude predstavljene su primercima luksuzne keramike, uglavnom zdela i tanjira izrađenih u tehnici terra sigillatae, koji su dospeli iz radionice za izradu tera sigilate Rajncabern. Od oblika tzv. glatke tera sigilate su forme Drag. 18/36, Drag.18/31 i Drag. 33. Reljefno ukrašene zdele pripadaju formi Drag. 37.

Prikazane posude datovane su, uglavnom, na osnovu analogija sa drugih lokaliteta, a datovanje dopunjuju i potvrđuju i nalazi novca. Oblici posuda pokazuju jednu unificiranu sliku lokalne keramičke proizvodnje tog vremena, kako u Meziji tako i u Panoniji i u Dakiji.

Sva keramika je izdvajana po celinama sa ciljem da se odrede hronološki okviri njenog trajanja. I pored takvog pokušaja nema većeg hronološkog osciliranja u materijalu, što potvrđuju i nalazi novca iz tih celina. Samo je prostor rova u kvadratima CD/IV nešto mlađi, dok sav ostali materijal pripada periodu od sredine II do sredine III veka. Istu vremensku odrednicu imali su i nalazi sa prostora nekropole oko Mauzoleja u čijoj se neposrednoj blizini ova sonda i nalazi. Nakon analize celokupnog arheološkog materijala početna ideja da je objekat u Sondi 29 deo lomače, nije se održala. Tragovi kolja koji se javljaju na jednakom rastojanju, te velika količina zapečene zemlje u različitim tonovima kako crvene tako i sive boje, mogla je da govori u korist ove teze, dok su ostale činjenice ukazivale na nešto drugo. Pre svega, o tome da se radi o odlagalištu (otpadu), a ne o zajedničkoj lomači (ustrinum). U prilog ovoj drugoj tezi, izneli bismo raznolikost nalaza na osnovu kojih se mogu pratiti periodična nasipanja i ravnanja zemlje, te prekopavanja i ponovna nasipanja. Nađene keramičke posude ukazuju na to da je neki drugi prostor rasčišćavan, a da je potom sav materijal deponovan u jednu veliku rupu. Naime, smenjuju se slojevi nagorele zemlje sa slojevima gari i pepela, podne pločice i delovi zidnog maltera, tragovi kolja i glinovita zemlja. Međutim, ako prostor sonde 29 posmatramo kao deponiju korišćenu za rasčišćavanje prostora oko nekropole za potrebe novih grobova ili za lomaču, nameće se pitanje zastupljenosti staklenih posuda. Odnosno oblici koji se najčešće nalaze kao grobni prilozi su toaletne bočice i to od I veka pa kasnije, a mi na ovom prostoru nismo našli fragmente balsamarija, nego zdela i prizmatičnih boca koje su pogodnije za korišćenje u svakodnevnom životu. Ono što je iznenađujuće je i izuzetno velika količina koštanih igala. Nađeno je preko 70 komada, što fragmentovanih, što celih. Ovakva situacija ukazuje da se radi o žrtvenom sloju nastalom prilikom daća, na šta ukazuje i činjenica da se keramički materijal razlikuje od grobnih priloga nekropole uz čiju samu ivicu se prostire. Pretpostavlja se da posle obavljenih daća nije vršeno redovno čišćenje nekropole. Zbog toga na terenu imamo primetnu sliku nasipanja, ravnanja i ponovnog nasipanja različitih slojeva zemlje pomešanih sa arheološkim materijalom. Nalazi od metala su prilično oštećeni i jako korodirani, pa nisu u potpunosti prepoznati, ali ipak ukazuju na to da se radi o raznim alatkama, delovima lanaca, alkama i zakivcima. Treba napomenuti da nije nađen ni jedan zlatan ili neki luksuzniji predmet, s obzirom da se u neposrednoj blizini nalazi nekropola sa izuzetno bogatim grobovima. Najveći deo keramičkog materijala je proizvod domaće radionice, a većina oblika rađena je po uzoru na importnu rimsku keramiku. Pošto je Viminacijum imao razvijenu grnčarsku proizvodnju, sasvim je izvesno da je najveći deo posuda proizveden upravo u Viminacijumu. Lokalna produkcija je dominantna i za ostale nalaze. S obzirom da istra- 
živanje šireg prostora oko nekropole na Pirivoju nije završeno, mogu se očekivati otkrivanja sličnih površina, a sa njima i rasvetljavanje situacije oko nekropole. Georadarskim istraživanjima uočeno je da se u blizini, istočno od ovog prostora nalazi objekat većih dimenzija koji još nije arheološki ispitan. Teza koju u ovom trenutku zastupamo je da se, prema analiziranom materijalu i situacijama, radi o prostoru koji je nastao čišćenjem i poravnavanjem žrtvenih površina nekropole.

\section{LITERATURA}

\section{Bjelajac 1978}

Lj. Bjelajac, Srednjovekovna keramika sa Dorćola, Godišnjak grada Beograda XXV, 1978, 133-144.

\section{Bjelajac 1990}

Lj. Bjelajac, Terra sigillata u gornjoj Meziji. Beograd, 1990.

\section{Bjelajac 1996}

Lj. Bjelajac, Amfore gornjo mezijskog Podunavlja, Beograd 1996.

\section{Brukner 1981}

O. Brukner, Rimska keramika u jugoslovenskom delu provincije Donje Panonije, Beo$\operatorname{grad} 1981$.

\section{Cvjetičanin 1996}

T. Cvjetičanin, Some Observation about Pottery Evidence from Diana, Roman limes on the Middle and Lower Danube, Belgrade 1996, 93-100.

\section{Hilgers 1969}

W. Hilgers, Lateinsche Gefässnamen, Bezeichungen, Funktion, und Form Römischer Gefäse nach den antiken Schrifguellen, Düsseldorf, 1969.

\section{Garašanin, Vasić... 1984}

M. Garašanin, M.Vasić, G. Marjanović Vujović, Trajanov most - Castrum Pontes, Đerdapske sveske II, Beograd 1984, 25-84.

\section{Korać 1995}

M. Korać, Žišci sa teritorije Viminacijuma, doktorska teza u rukopisu, Beograd 1995.

\section{Krunić 2005}

S. Krunić, Pregled antičkih svetiljki Singidunuma, Singidunum 4, Beograd 2005.

\section{Nikolić-Đorđević 2000}

S. Nikolić-Đorđević, Antička keramika Singidunuma, Singidunum 2, Beograd 2000, 11-245.

\section{Milovanović 2008}

B. Milovanović, Rimsko olovo u Srbiji eksploatacija, proizvodnja i upotreba, doktorska teza u rukopisu, Beograd 2008. godine.

\section{Petković 1995}

S. Petković, Rimski predmeti od kosti $i$ roga, Beograd 1995.

\section{Petrović 1997}

B. Petrović, Nakit u: Antička bronza Singidunuma (ed. S. Krunić), Beograd 1997, 154.

\section{Popilian 1976}

G. Popilian, Ceramica Romana din Oltenia, Craiova 1976.

\section{Popović 1988}

I. Popović, Antičko oruđe od gvožđa u Srbiji, Beograd 1988.

\section{Raičković 2007}

A. Raičković, Keramičke posude Zanatskog centra iz Viminacijuma, Beograd 2007.

\section{Redžić 2007}

S. Redžić, Nalazi rimskih fibula na nekropolama Viminacijuma, Beograd 2007.

\section{Ružić 1994}

M. Ružić, Antičko staklo u Srbiji, Beograd 1994.

\section{Sultov 1985}

B. Sultov, Ceramic Production on the Territory of Nicopolis ad Istrum (II-nd - IV-th century), Sofia 1985. 


\section{Zotović, Jordović 1990}

Lj. Zotović, Č. Jordović, Viminacium: nekropola , Višse grobalja“, Beograd 1990.

\section{RESEARCH RESULTS OF THE SOUTHWEST PART OF THE SITE PIRIVOJ (VIMINACIUM)}

In the area of the sounding 29, in the vicinity of the Pirivoj necropolis in Viminacium, a surface was found, which was first identified as sacrificial area. Since no graves were found either udner or near this surface, this theory was abandoned. For the time being, one can suppose that it is a deposit consisting of material removed from some nearby sacrificial area. In layers of red burned soil, clay and earth mixed with sooth, many pottery and oil-lamp shards were found, pieces of glass vessels, further on decorative and sewing needles made of bone or bronze, bronze and iron tools and bronze coins. According to the material found, this deposit was dated into the period from the beginning of 2 nd to the beginning of 4 th century.

KEY WORDS: POTTERY VESSELS, OIL-LAMPS, BONE, GLASS, BRONZE, IRON, STONE, NECROPOLIS, VIMINACIUM.

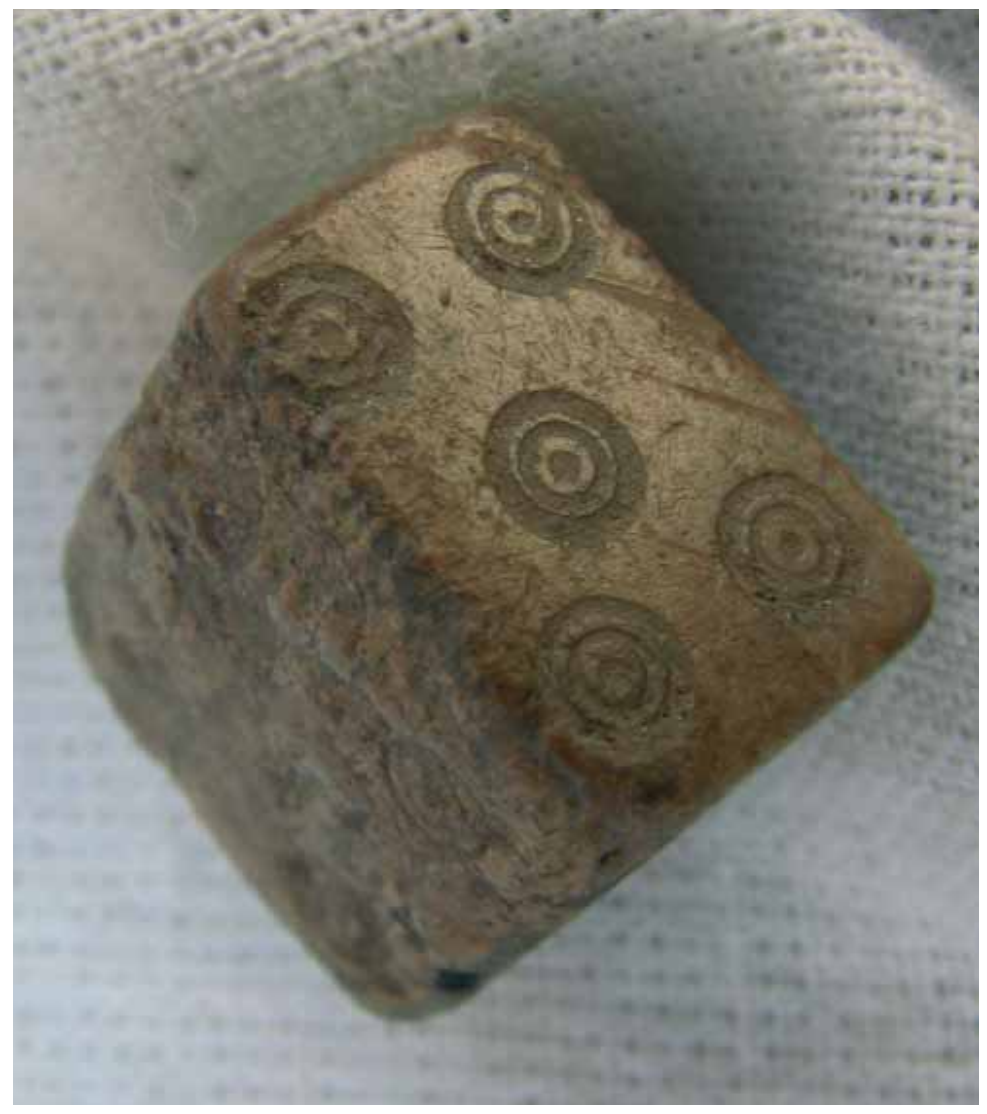

Koštana kockica otkrivena u sondi 29 na jugozapadnom delu lokaliteta Pirivoj (Viminacijum) 


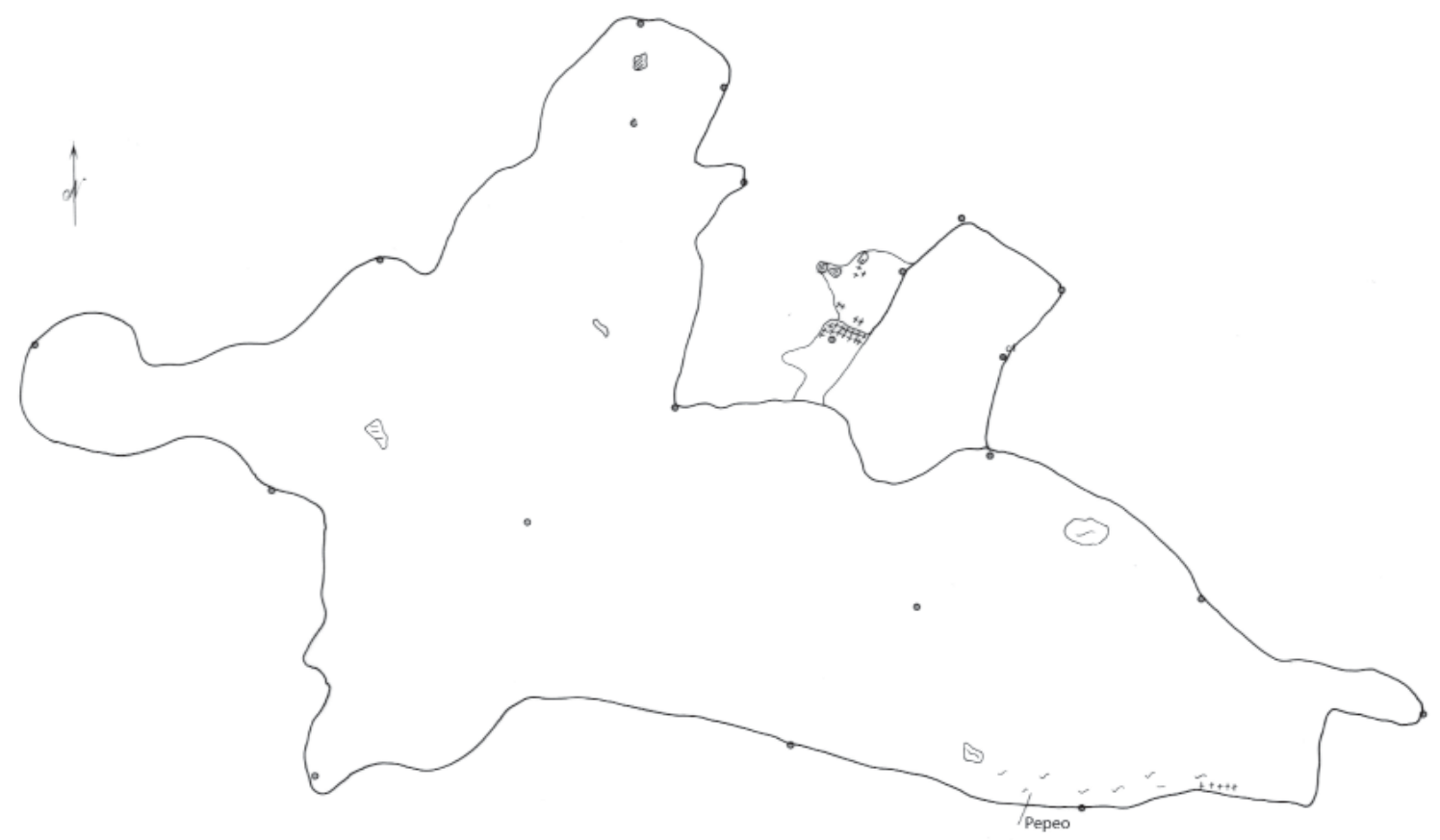

Plan 1a. Osnova površine sa crveno zapečenom zemljom oko ukopa kvadrati C/II - D/II
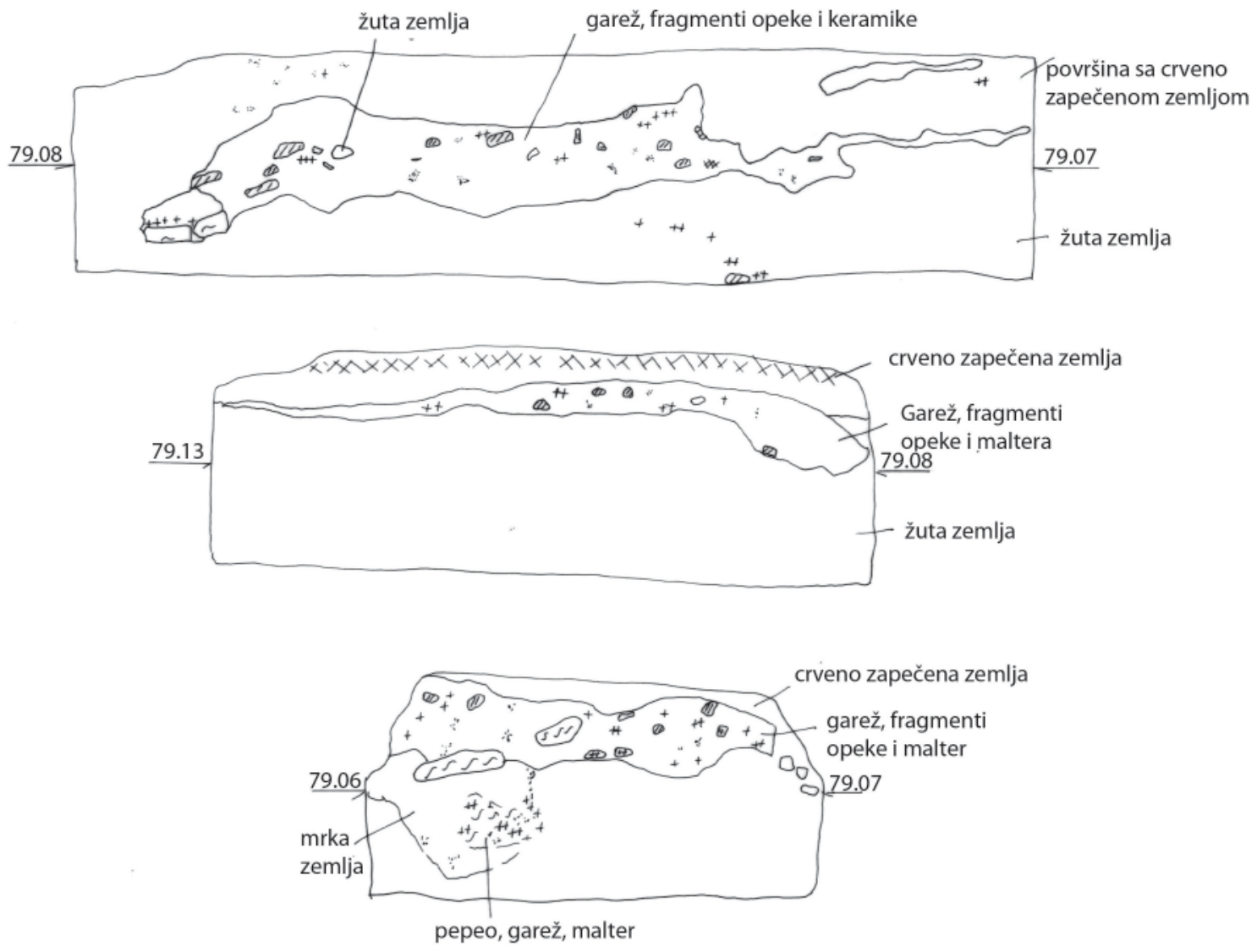

Plan 1b. Površina sa crveno zapečenom zemljom - profili 


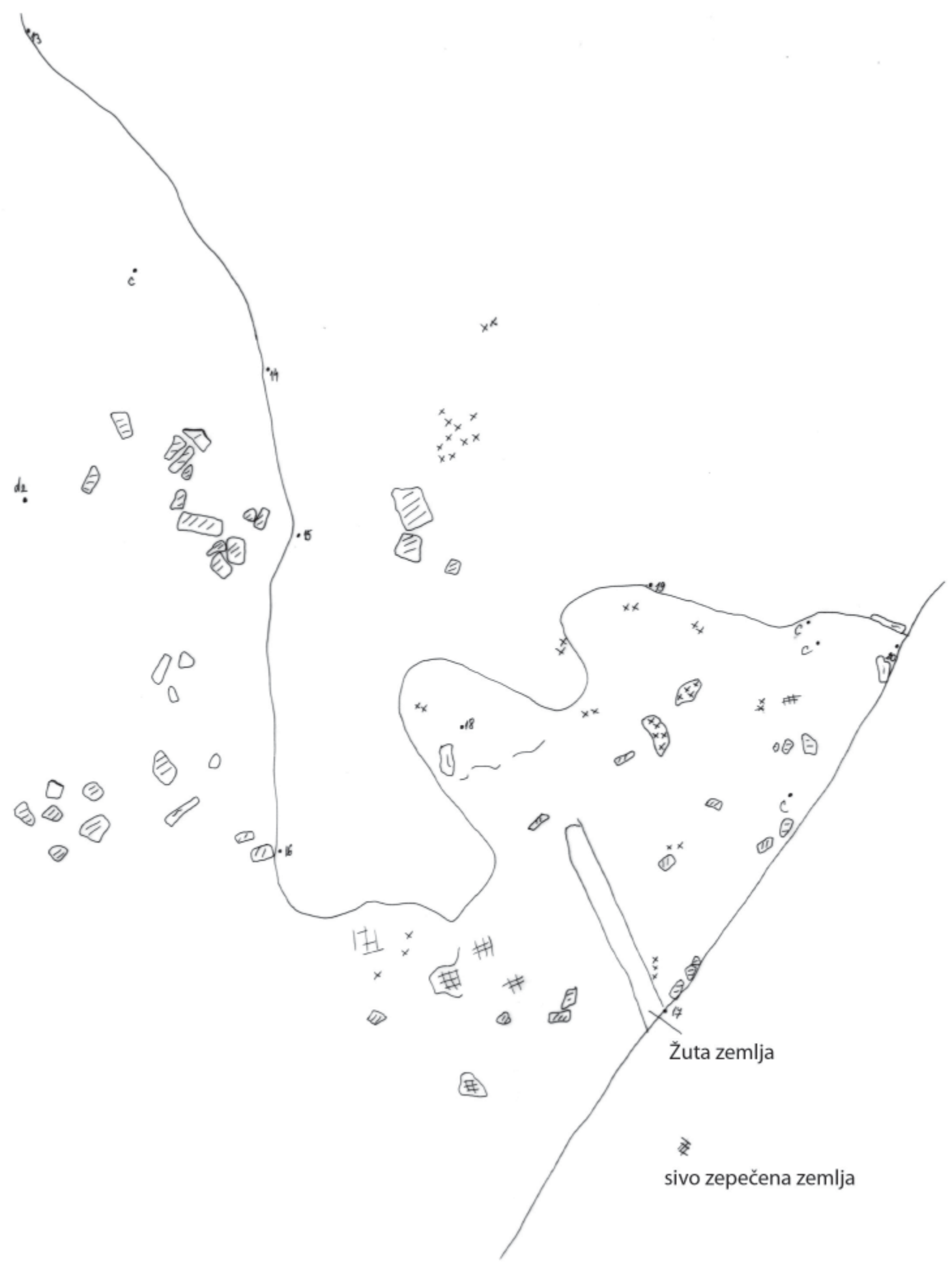

Plan 2. Osnova površine sa crveno zapečenom zemljom kvadrati E/II - E/III 


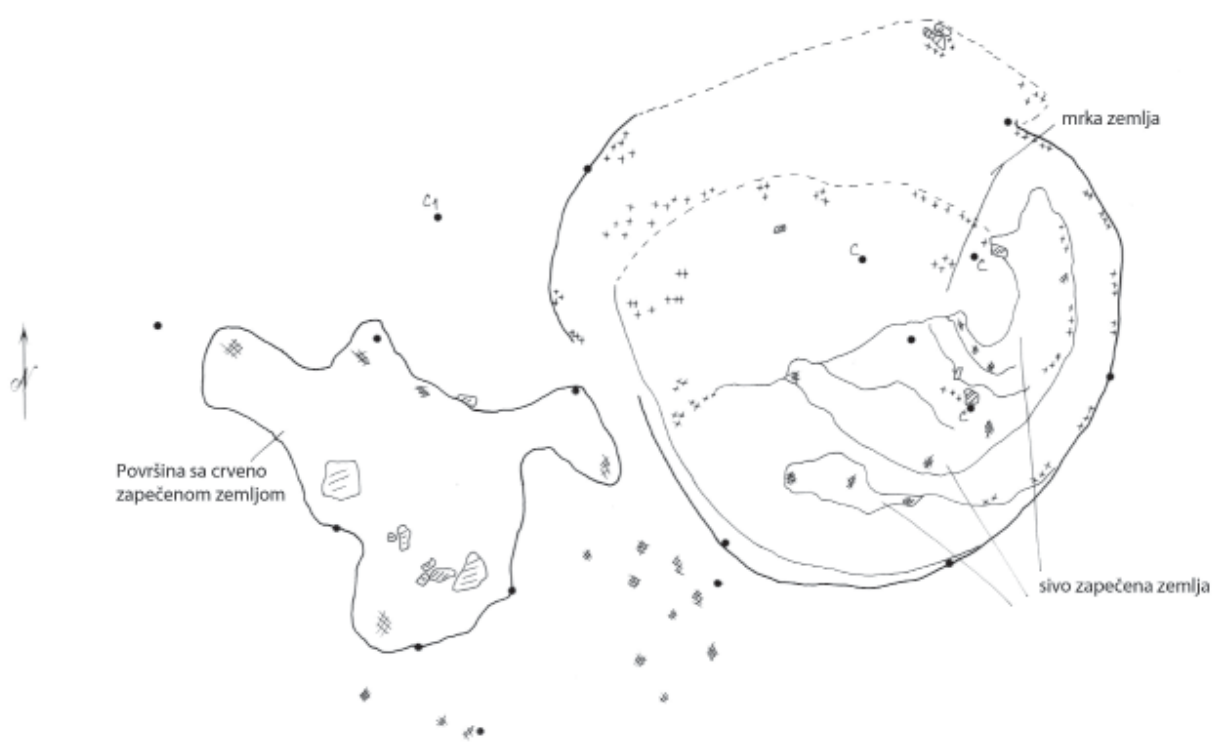

ukop 1 - presek (sa južne strane)

Presek A-A' (sa severne strane)
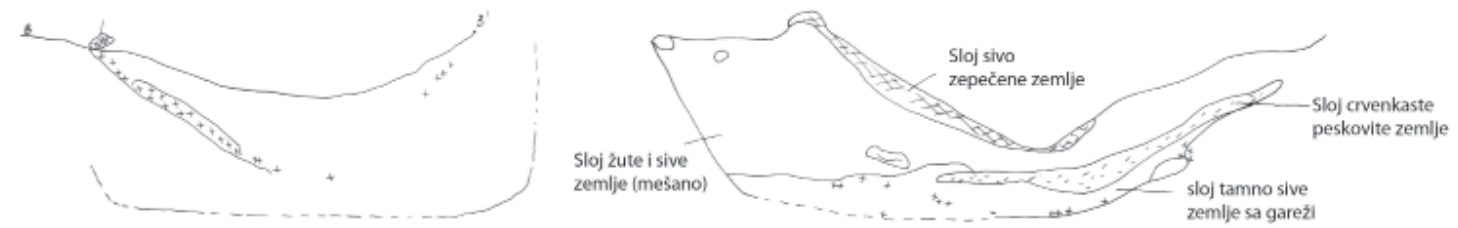

Plan 3. Osnova 1 ukopa 1, kvadrati D/I - D/II<smiles>C1CCCC1</smiles>

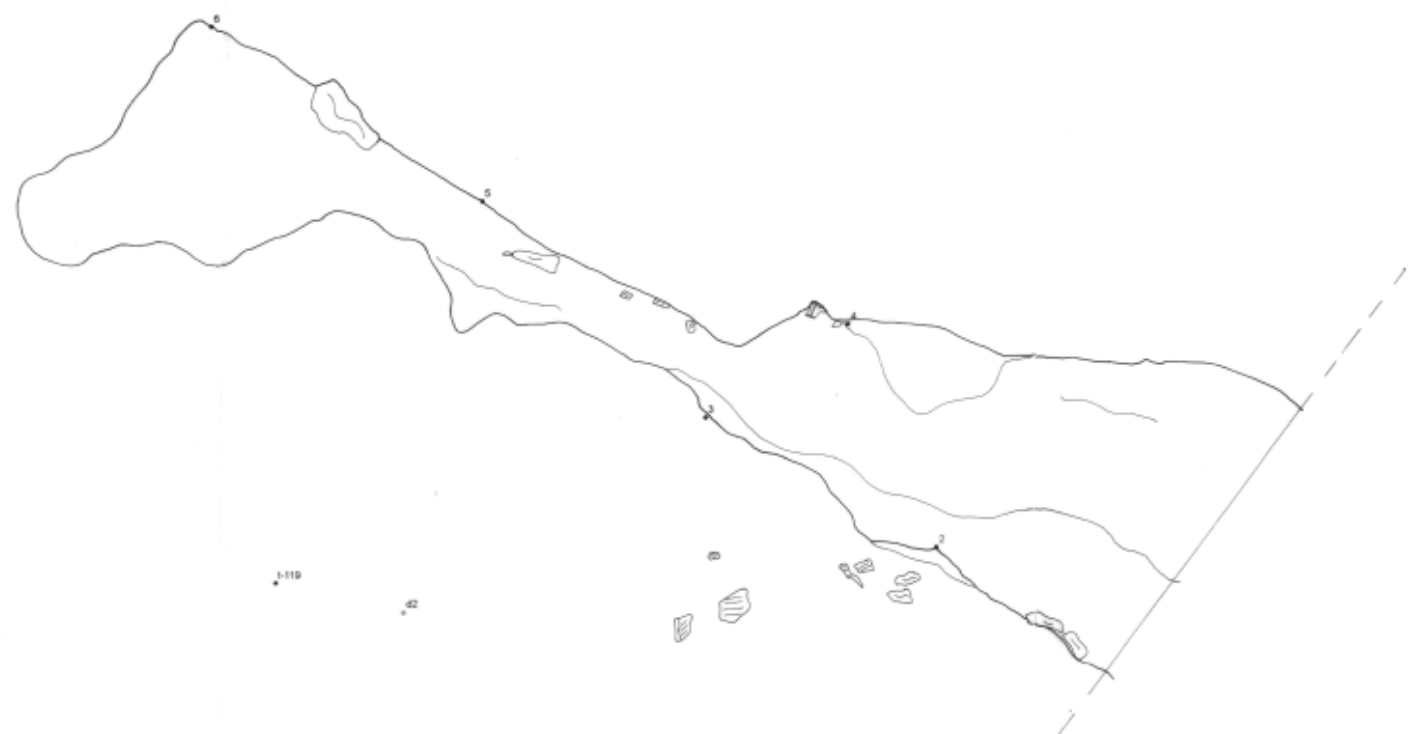

Plan 4. Osnova površine sa sivo zapečenom zemljom, kvadrat E/II - D/II 


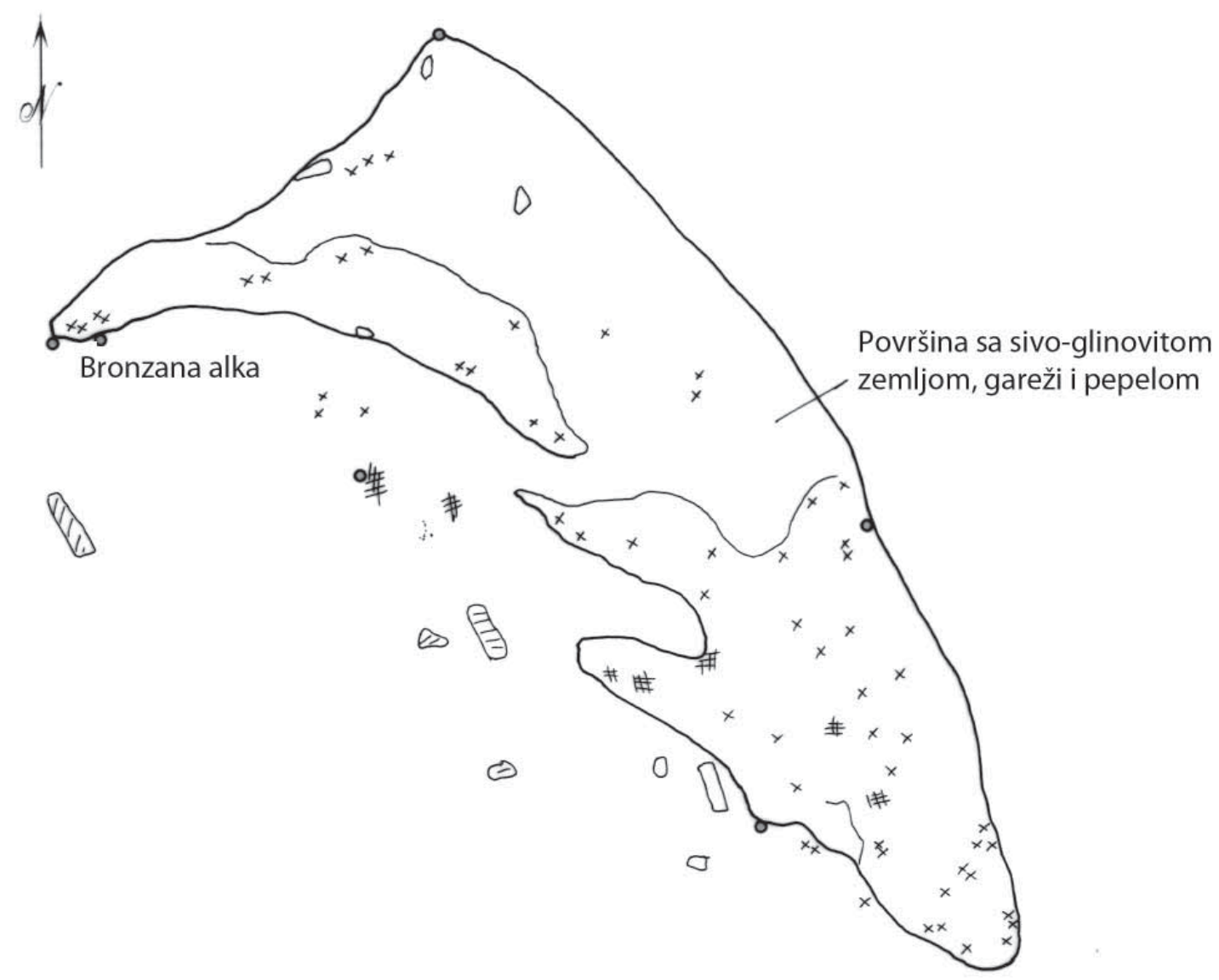

Plan 5. Osnova površine sa sivo glinovitom zemljom, gareži i pepelom kvadrat D/II - E/II

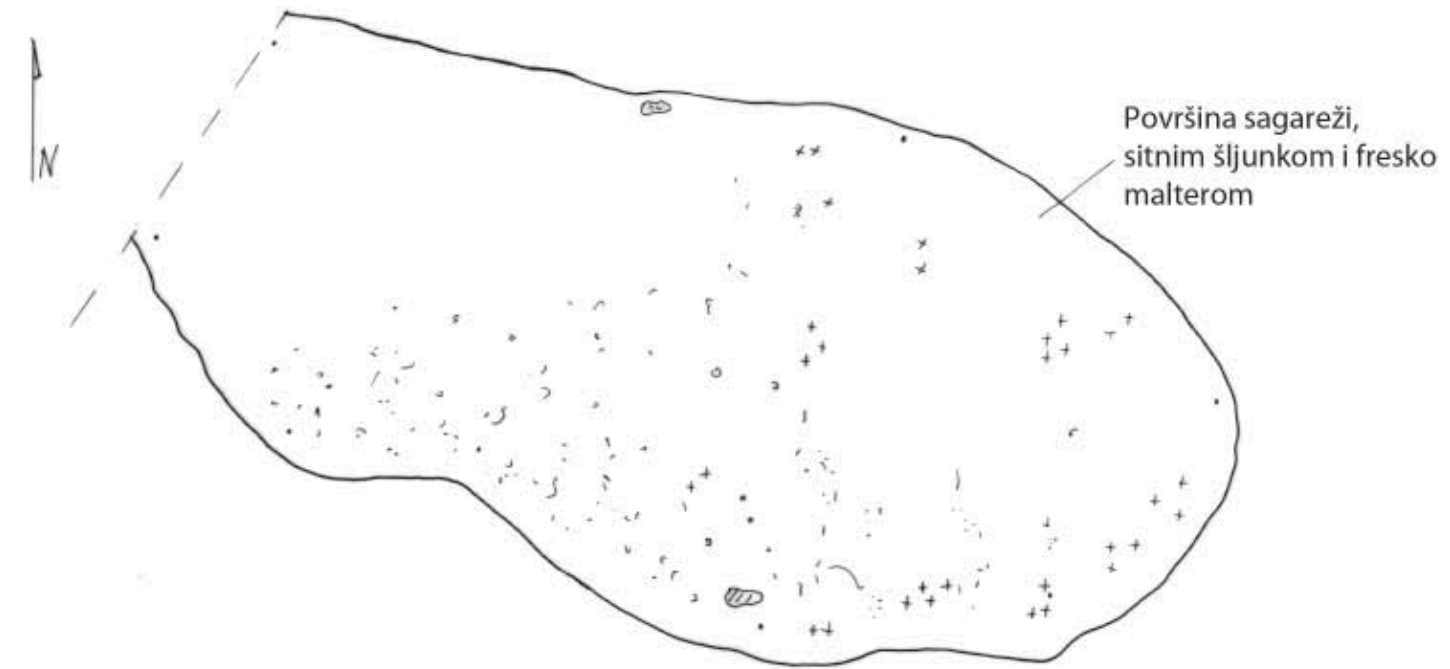

Plan 6. Osnova površine sa gareži, sitnim šljunkom i freskomalterom, kvadrat $\mathrm{C} / \mathrm{II}$ 

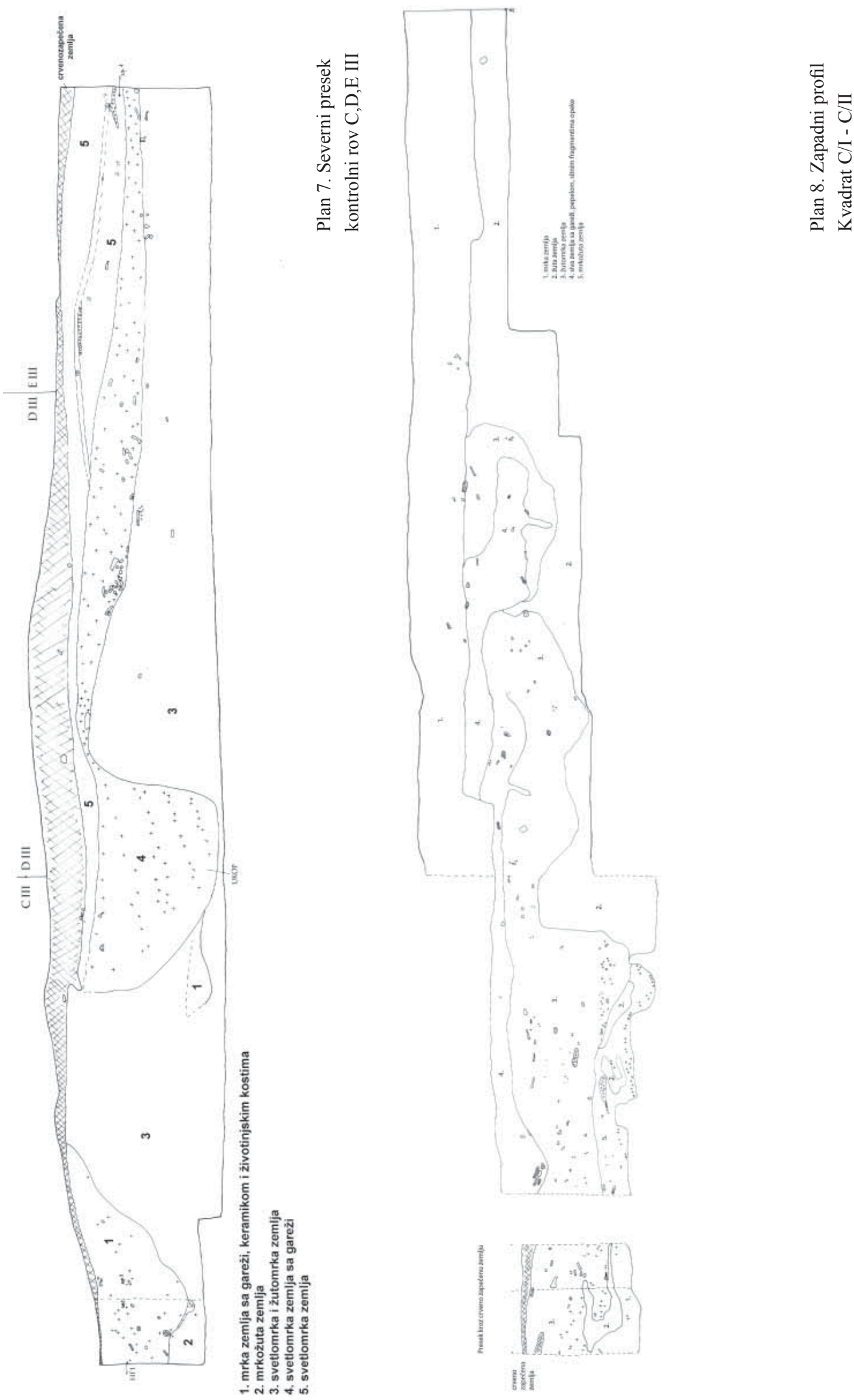

曹




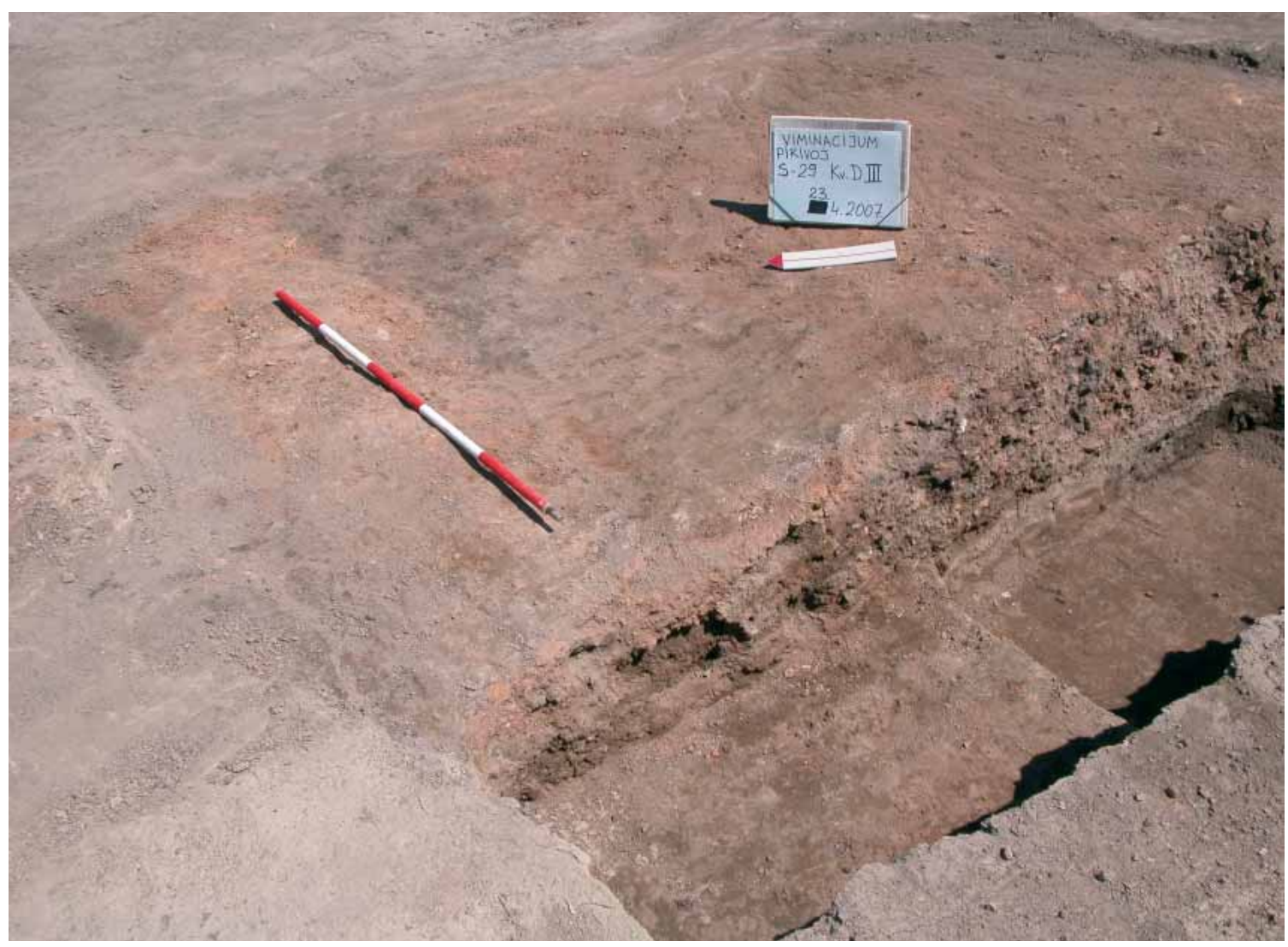

Sonda 29, kvadrat D III, presek površine sa zapečenom zemljom (gore).

Kvadrati C,D,E III profil kontrolnog rova (dole).

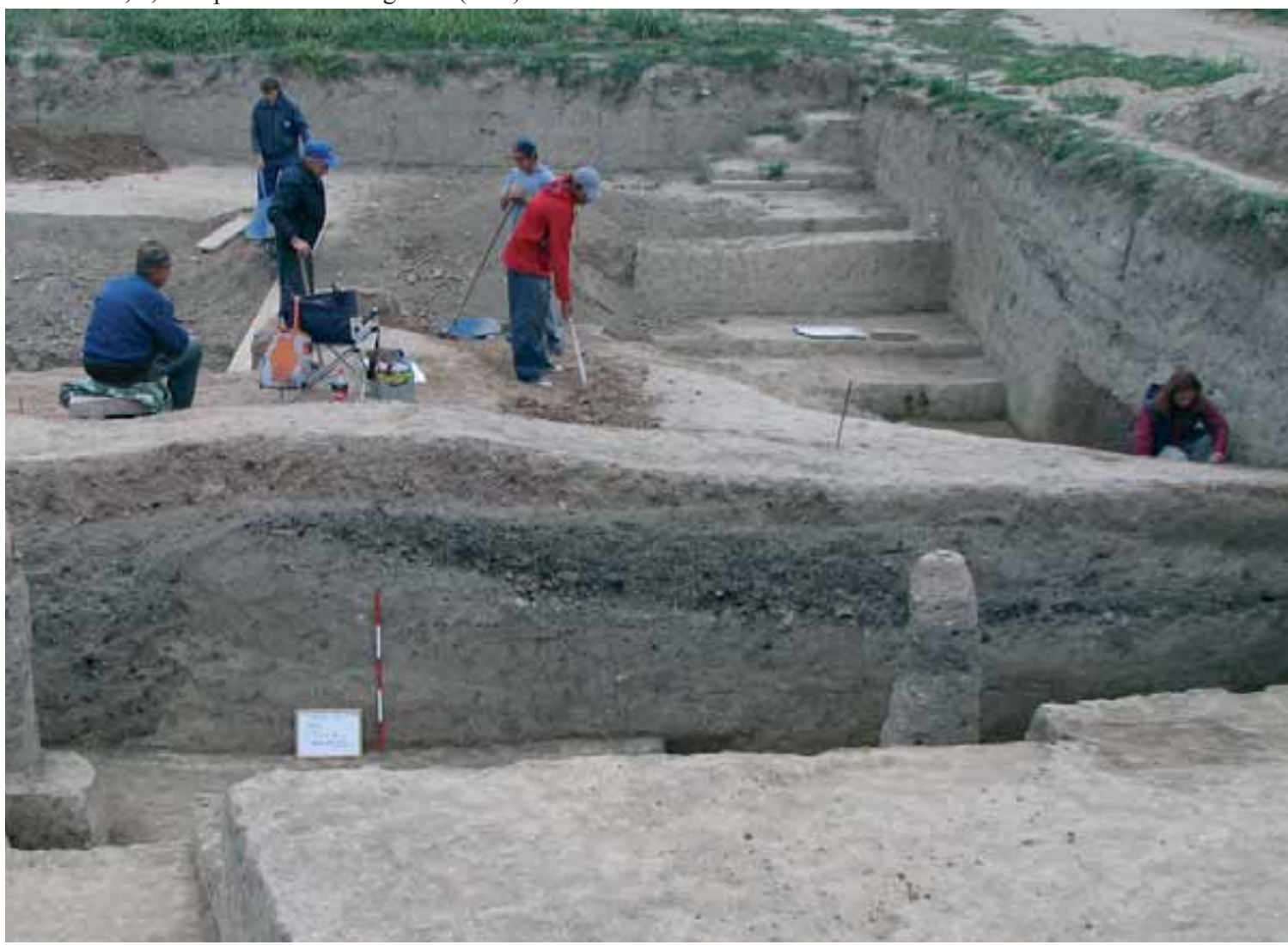


T. I
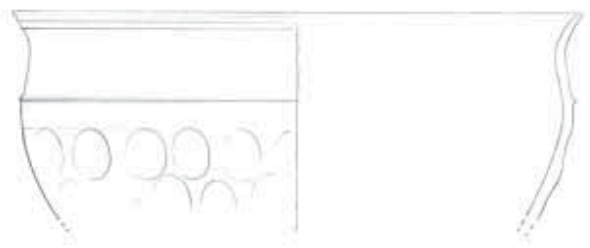

1
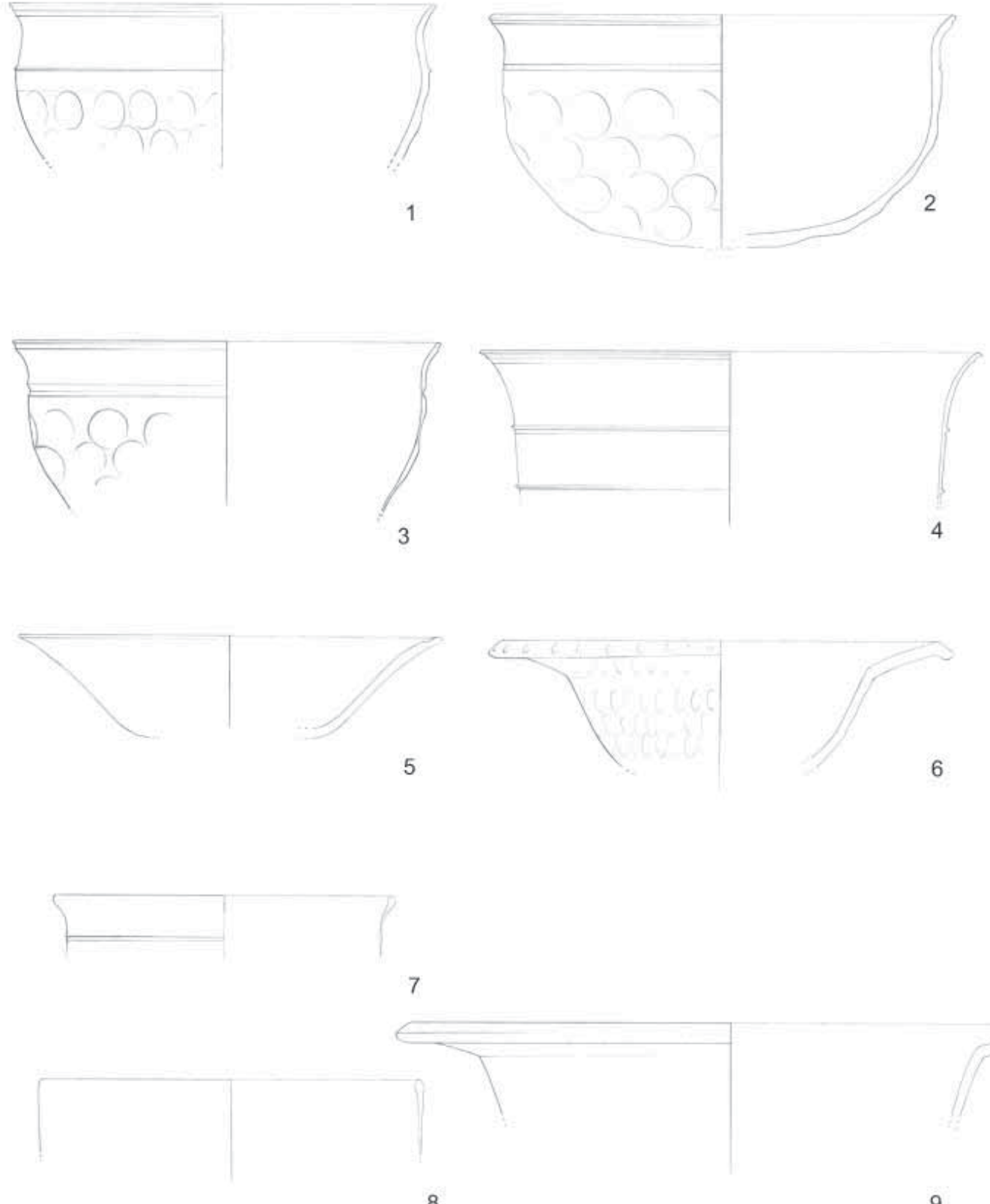

8
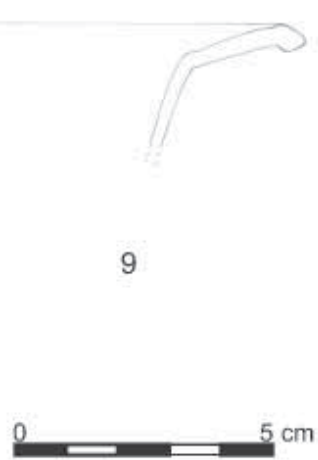

TABLA I

1 -C: 1199, 2 -C: 1237, 3-C: 1221, 4-C: 1218, 5-C: 1247, 6-C: 1235, 7-C: 1288, 8-C: 1213, 9-C: 1285 

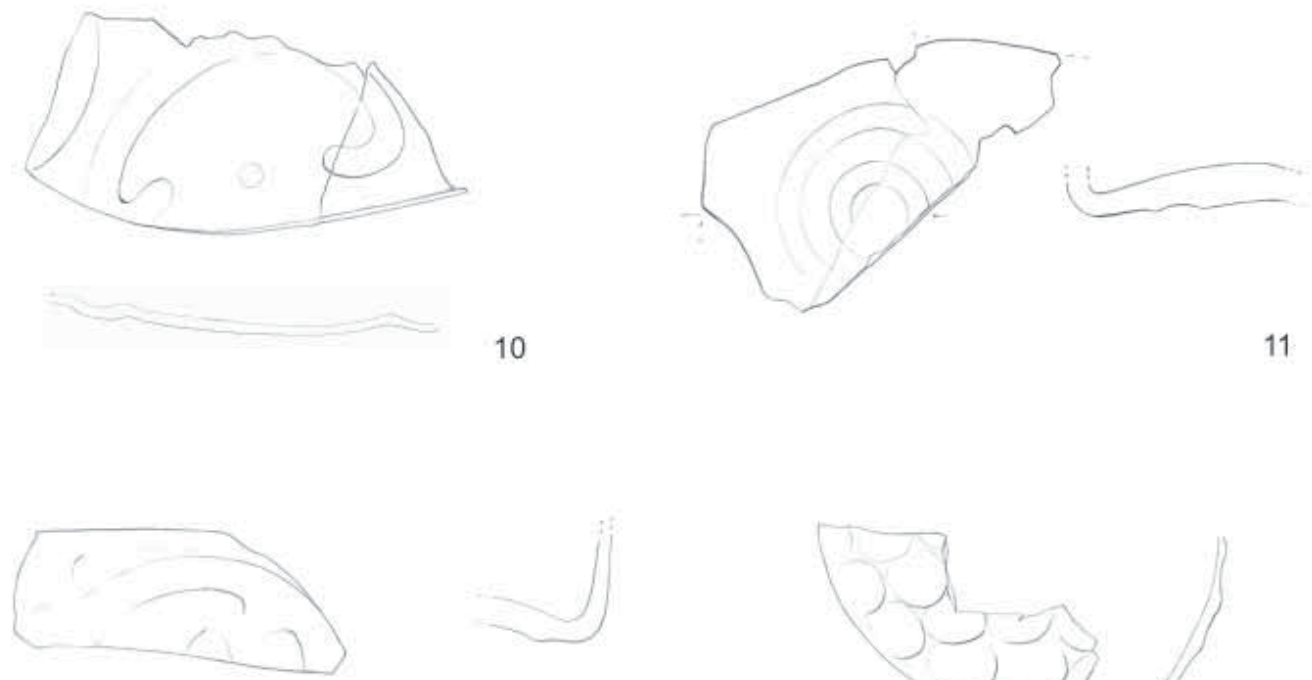

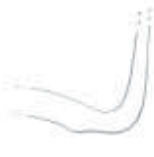

12

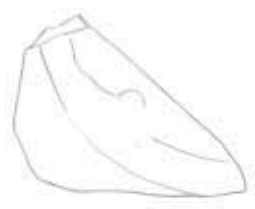

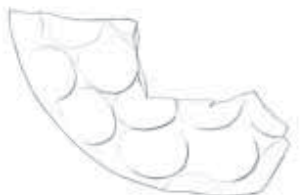

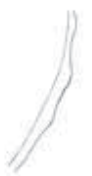

TABLA II

10 - C: $1171,11-\mathrm{C}: 1176,12$ - C: 1245,13 - C: 1187,14 - C: 1254,15 - C: 1099 
T. III
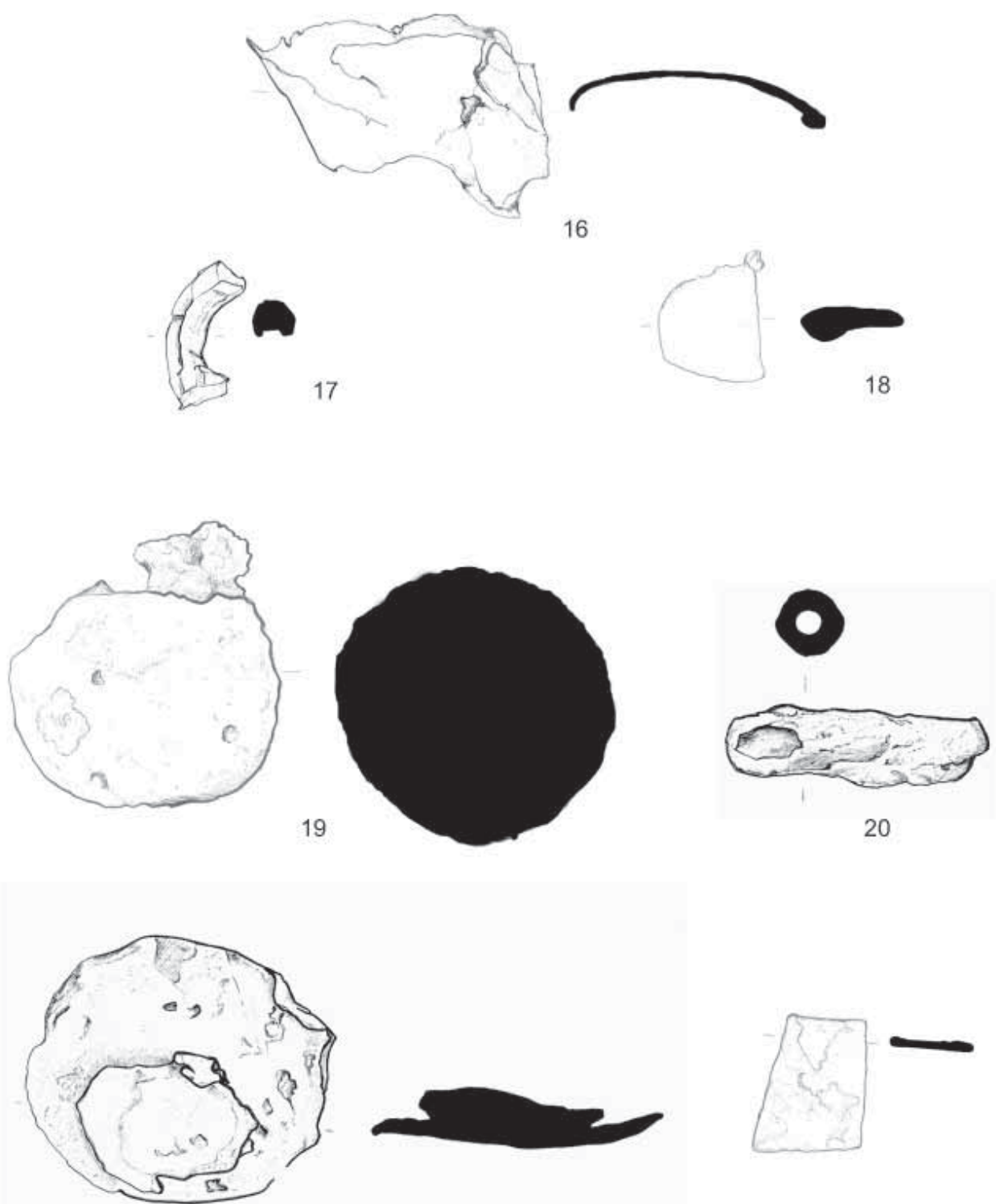

TABLA III

16 - C: $1168,17-\mathrm{C}: 1129,18-\mathrm{C}: 1246,19-\mathrm{C}: 1061,20-\mathrm{C}: 1125,21-\mathrm{C}: 1124,22-\mathrm{C}: 1260$ 

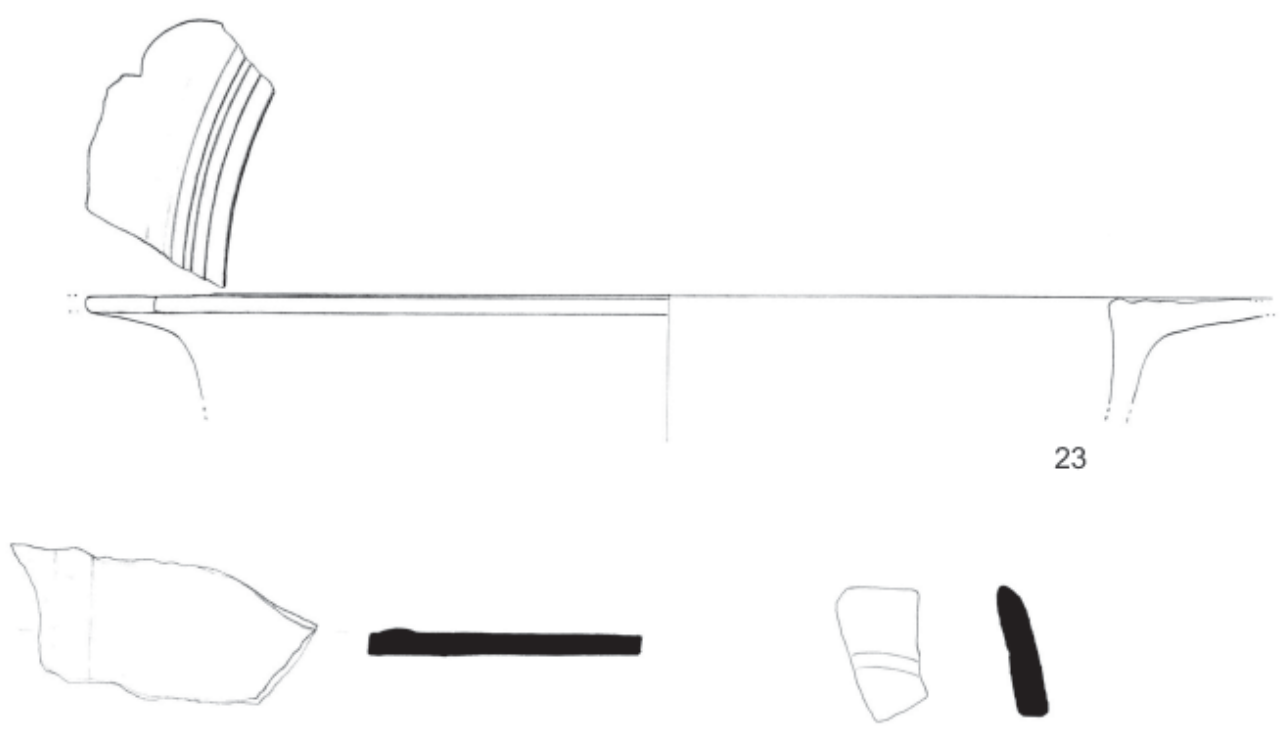

24
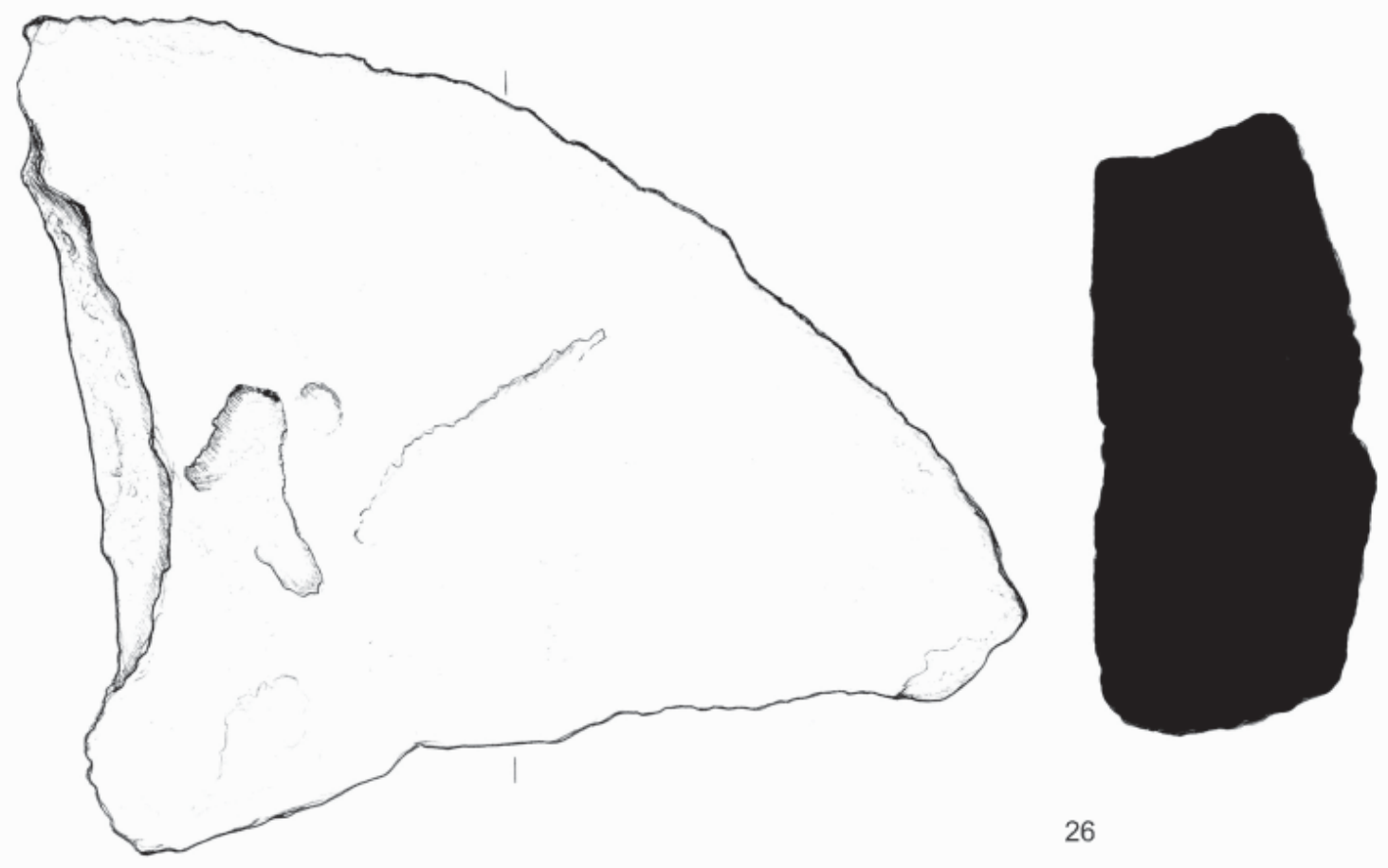

TABLA IV

23 - C: 1050, 24 - C: 1157,25 - C: 1041, 26 - C:1100 
T. V
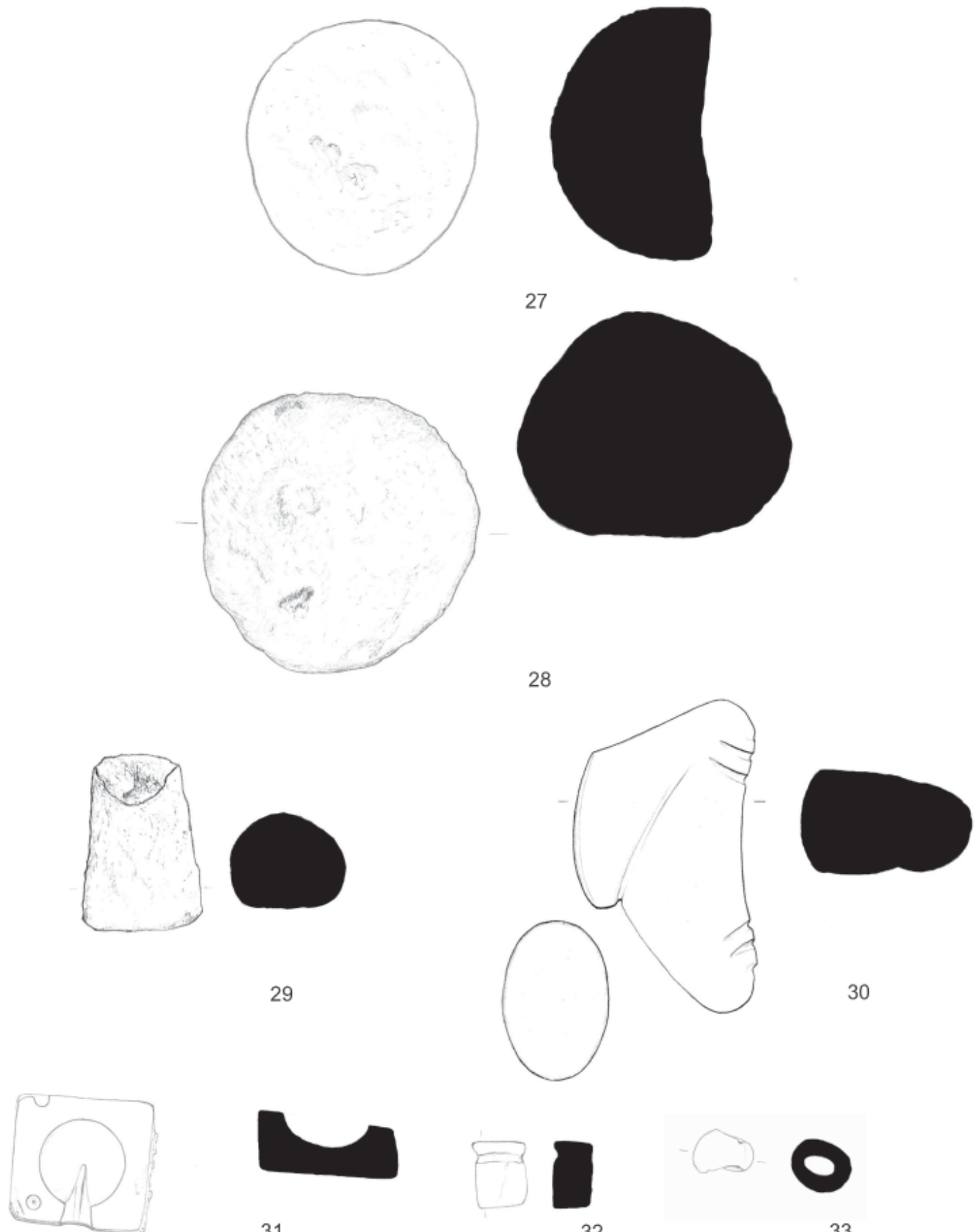

31

32

33

TABLA V

27 - C: 1269,28 - C: 1263, 29 - C: 1158, 30 - C:1121, 31 -C: 1074, 32 - C: 1234, 33 - C: 1280 

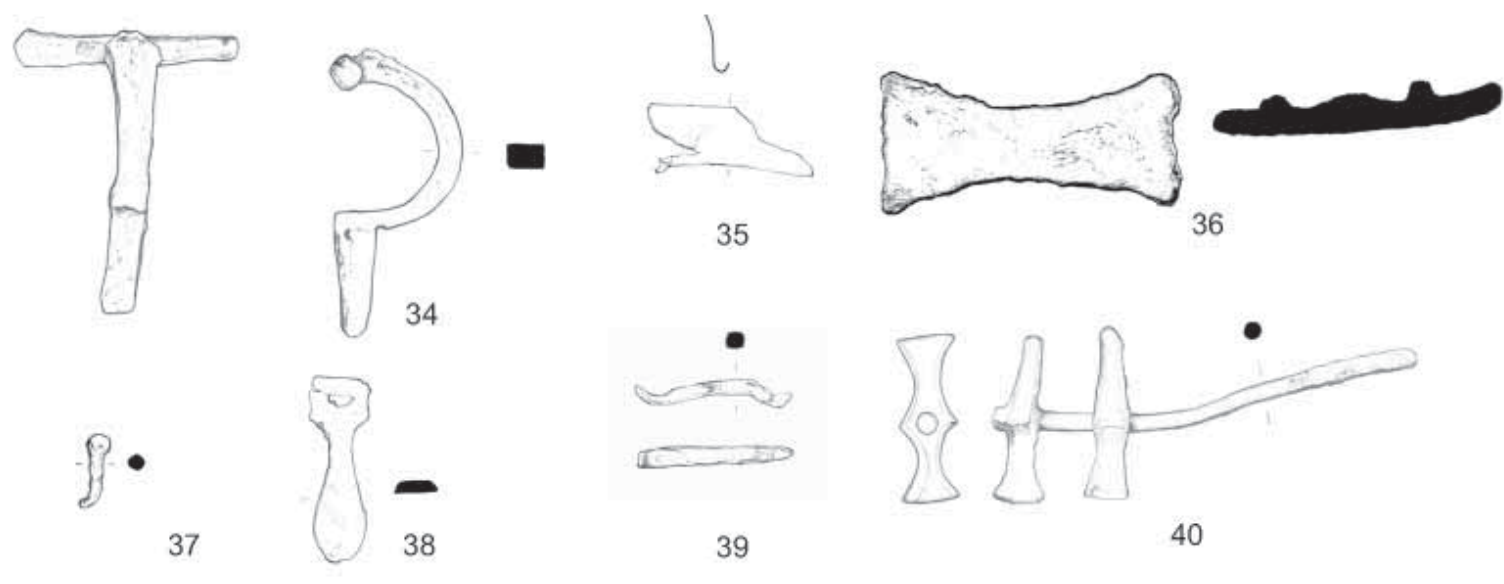

39

40
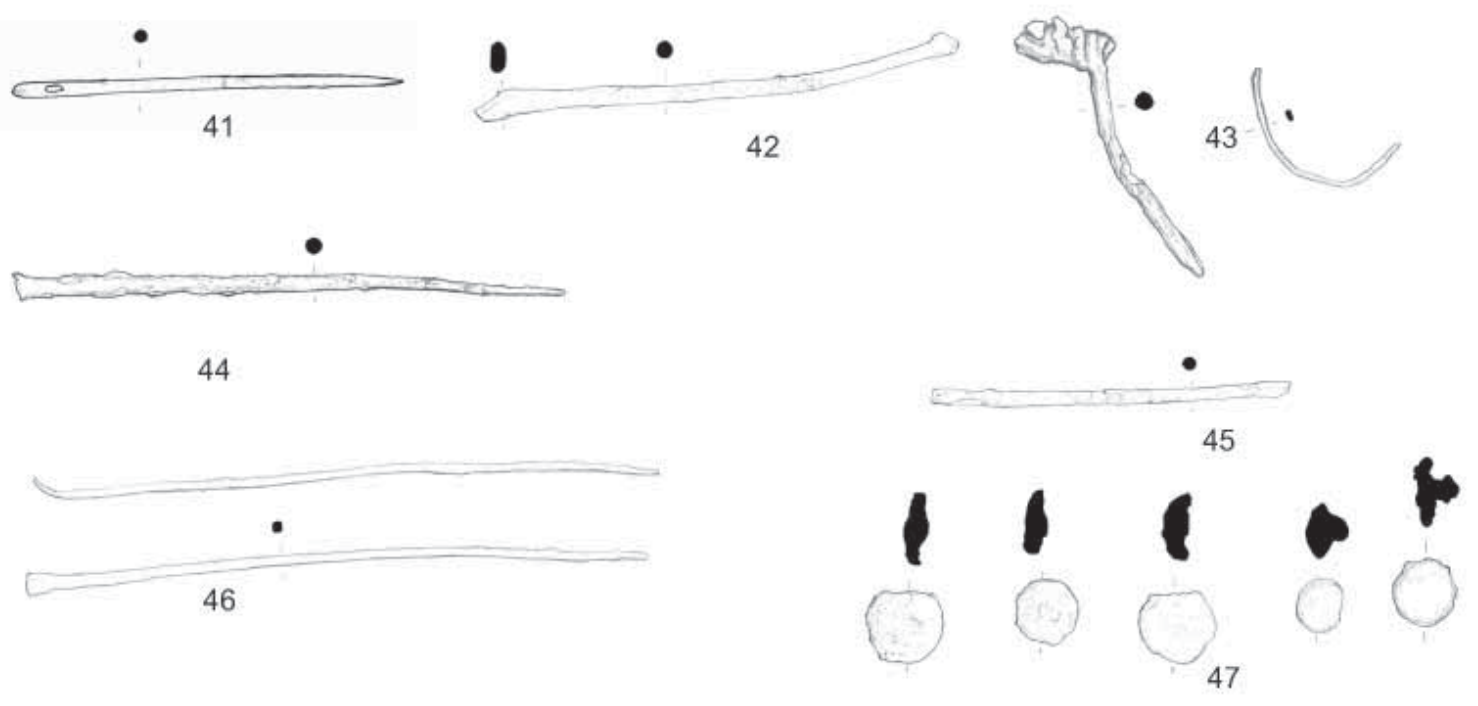

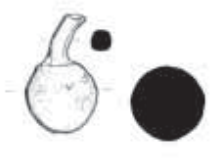

48
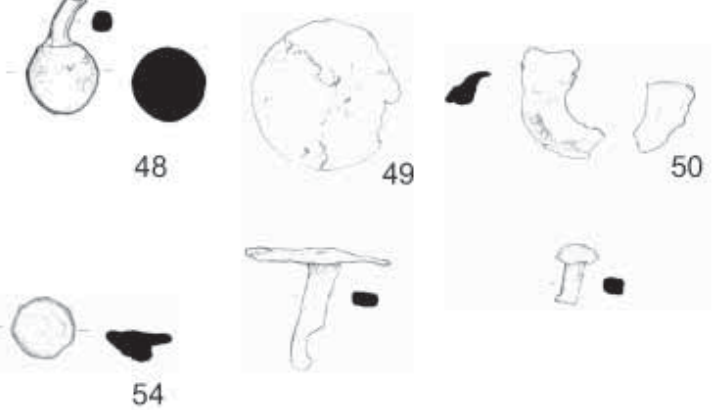
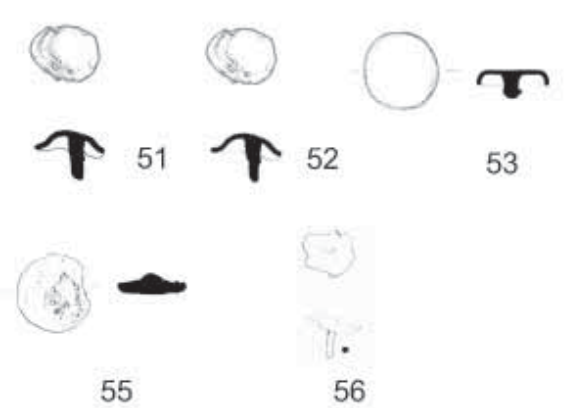

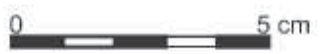

TABLA VI

34 - C:1042, 35 - C: 1170, 36 - C: 1141,37 - C: 1210,38 - C: 1207,39 - C: 1175,40 - C: 1056, 41 - C: 1123 , 42 - C: 1203, 43 - C: 1239, 44 - C: 1160,45 - C: 1205,46 - C: 1243,47 - C: 1196,48 - C: 1181, 49 - C: 1283 , 50 - C: $1266,51-\mathrm{C}: 1289,52$ - C: $1293,53-\mathrm{C}: 1228,54-\mathrm{C}: 1230,55-\mathrm{C}: 1202,56-\mathrm{C}: 1284$ 
T. VII
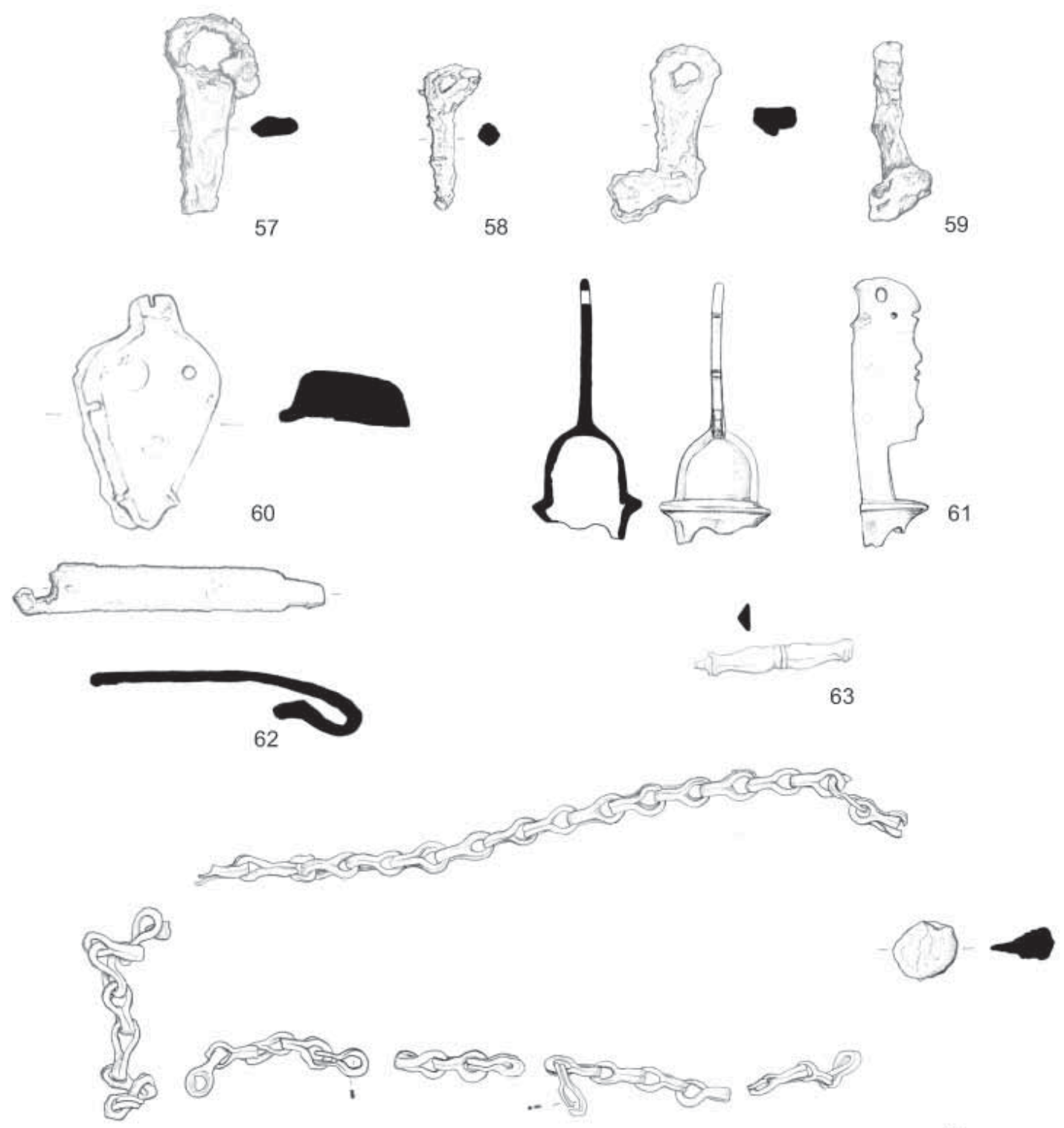

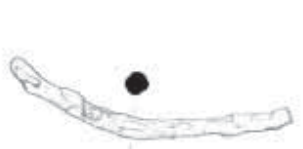

65

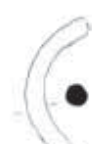

66
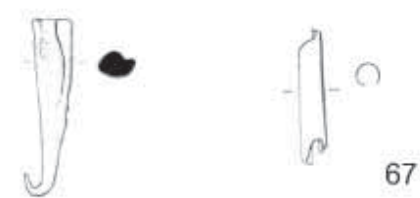

$5 \mathrm{~cm}$

57 - C: 1224, 58 - C: 1201, 59 - C: 1223, 60 - C: 1038, 61 - C: 1183, 62 - C: 1165, 63 - C:1268, 64 - C: 1192 , $65-\mathrm{C}: 1258,66-\mathrm{C}: 1256,67-\mathrm{C}: 1173$ 

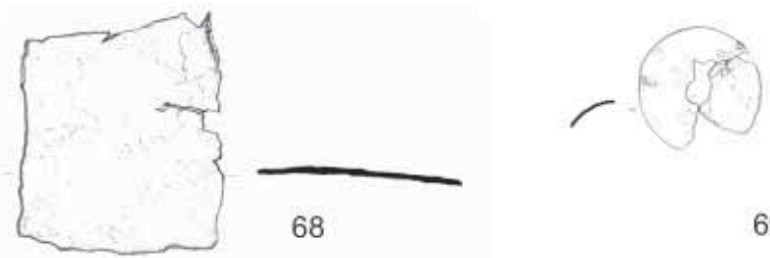

69

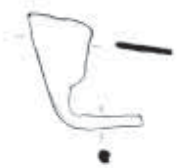

71
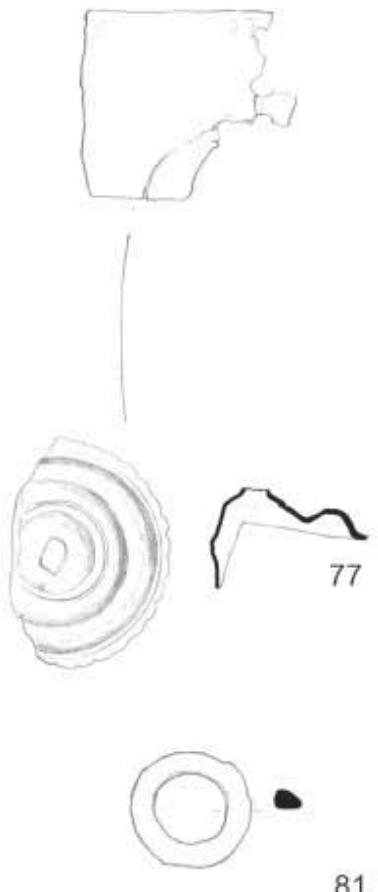

81
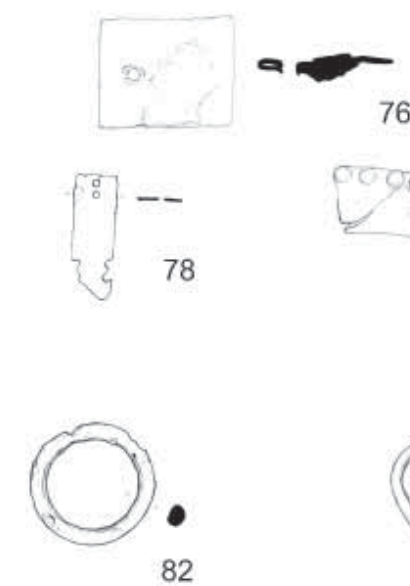

76

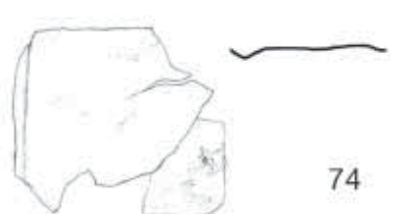

72
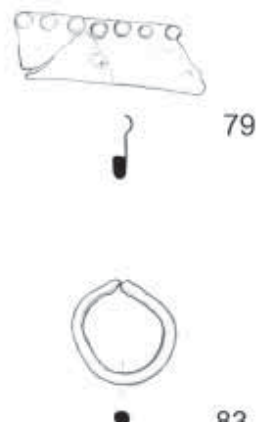

- 83

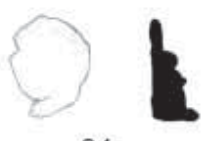

84
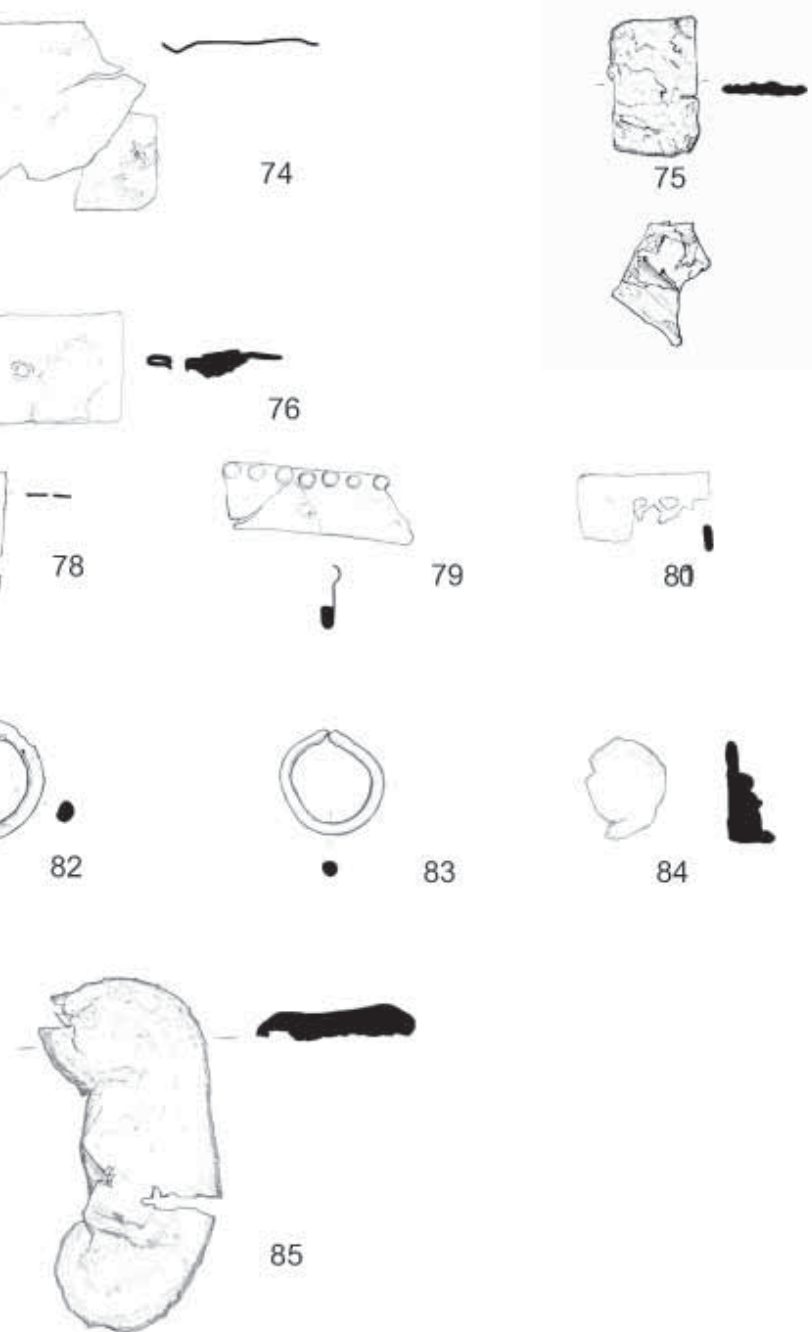

70

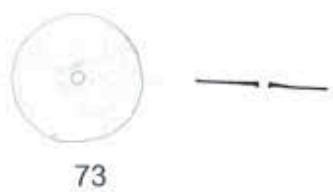

TABLA VIII

68 - C: 1198,69 - C: 1272,70 - C: 1231,71 - C: 1287,72 - C: $1277,73-$ C: 1075,74 V C: 1222,75 - C: 1126 ,

76 - C: 1226, 77 - C: 1265, 78 - C: 1286, 79 - C: 1180, 80 - C: 1253, 81 - C: 1279, 82 - C: 1195, 83 - C: 1159 , 
T. IX
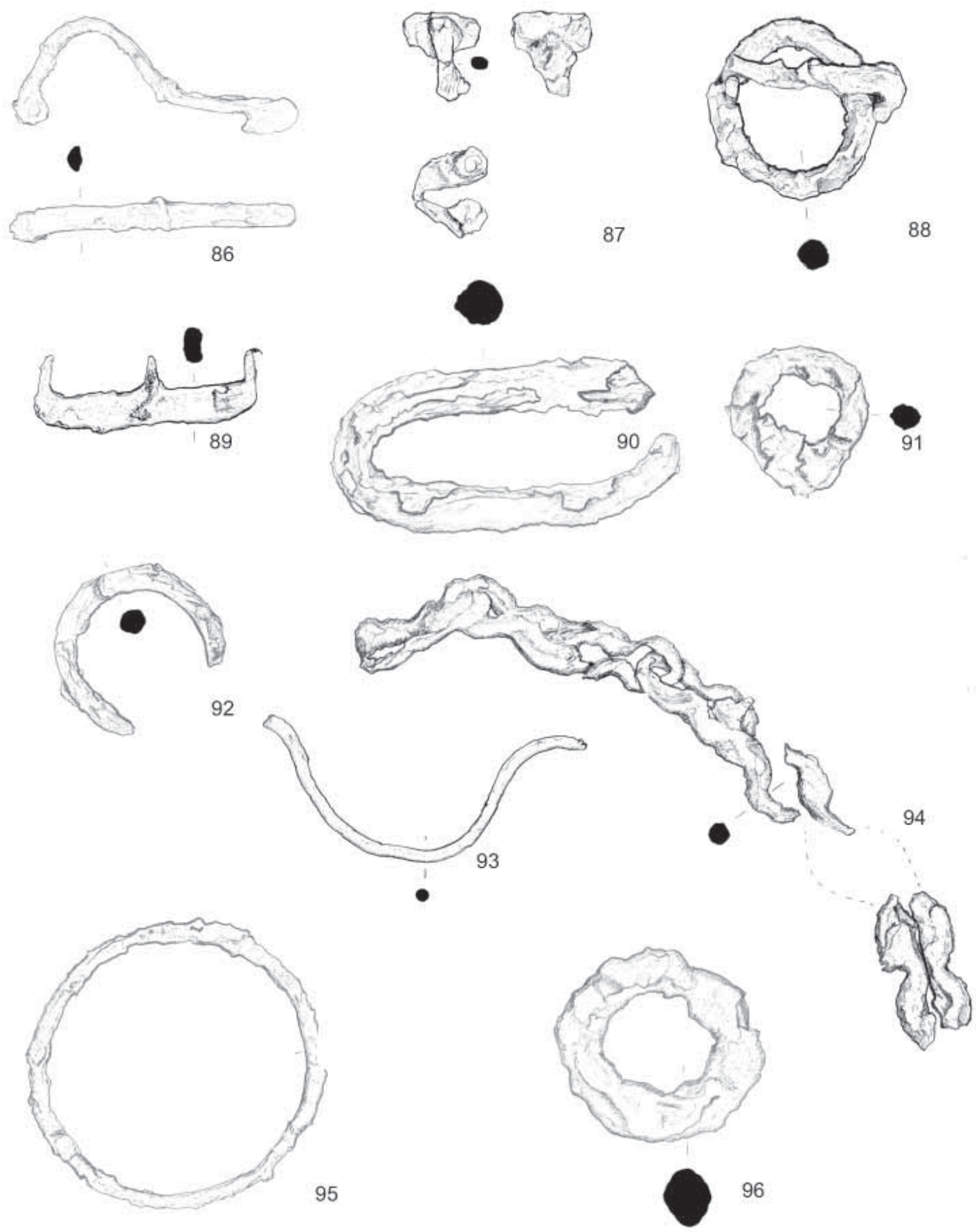

TABLA IX

86 - C: 1076, 87 - C:1161, 88 - C: 1145, 89 - C: 1136, 90 - C: 1292, 91 - C: 1291, 92 - C:1271, 93 - C:1092, $94-\mathrm{C}: 1169,95-\mathrm{C}: 1250,96-\mathrm{C}: 1229$ 


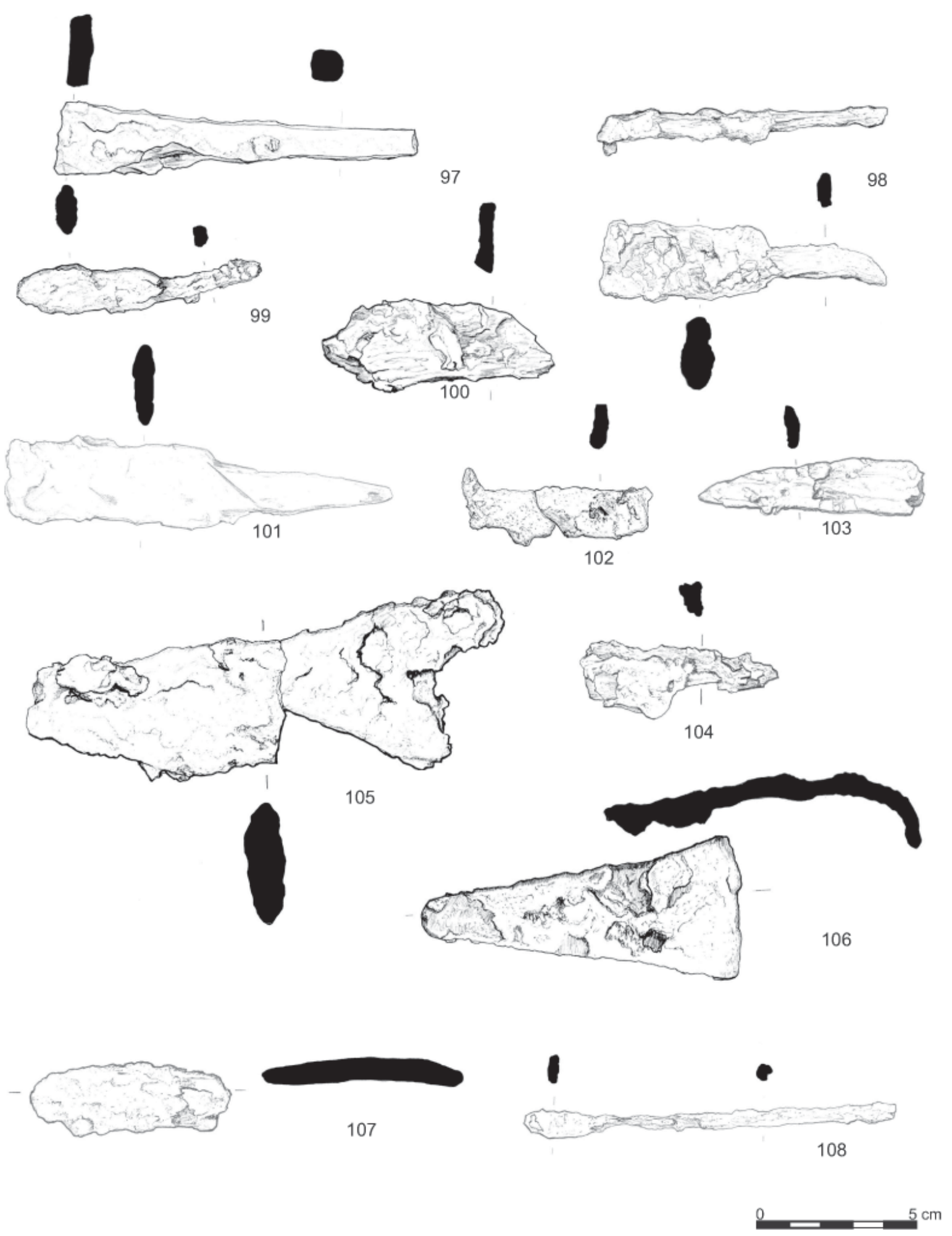

TABLA X

97 - C: 1101,98 -C: 1166,99 - C: 1130,100 - C:1138, 101 -C: 1216, 102 -C: 1106, 103 - C: 1278 , $104-\mathrm{C}: 1174,105-\mathrm{C}: 1112,106-\mathrm{C}: 1085,107-\mathrm{C}: 1274,108-\mathrm{C}: 1062$ 
T. XI
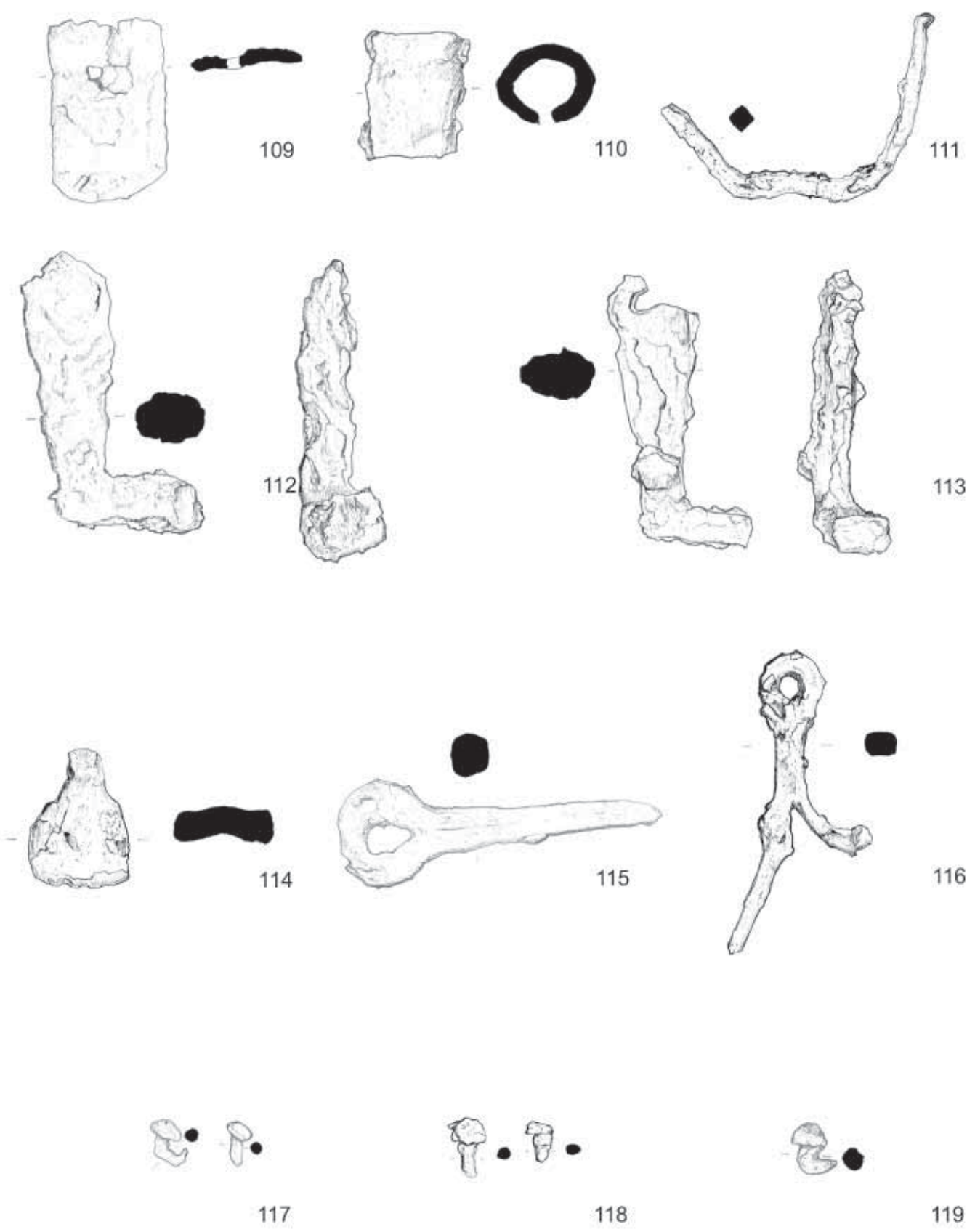

TABLA XI

109 - C: 1249,110 - C: 1197,111 - C: 1117,112 - C: 1209, 113 - C:1193, 114 -C: 1140 , 115 - C: $1244,116-C: 1083,117-C: 1215,118-C: 1102,119-C: 1275$ 

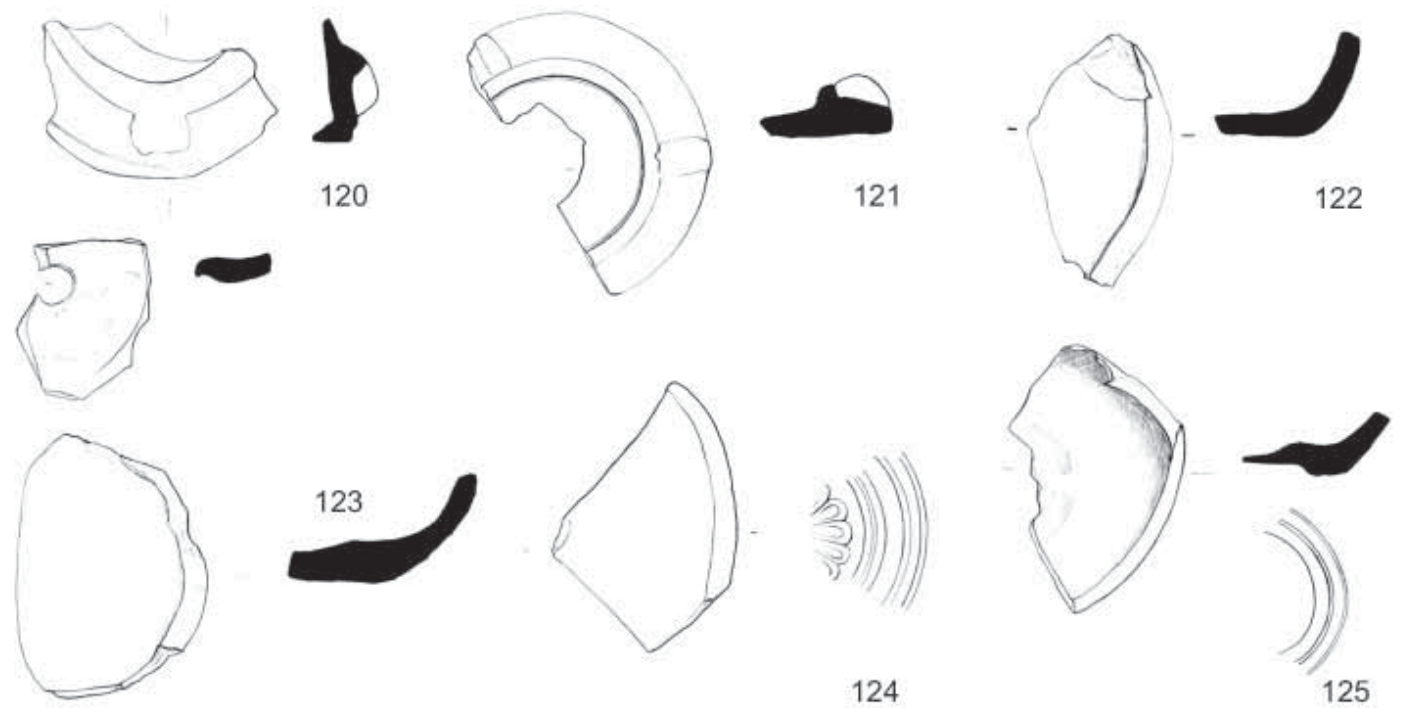

124
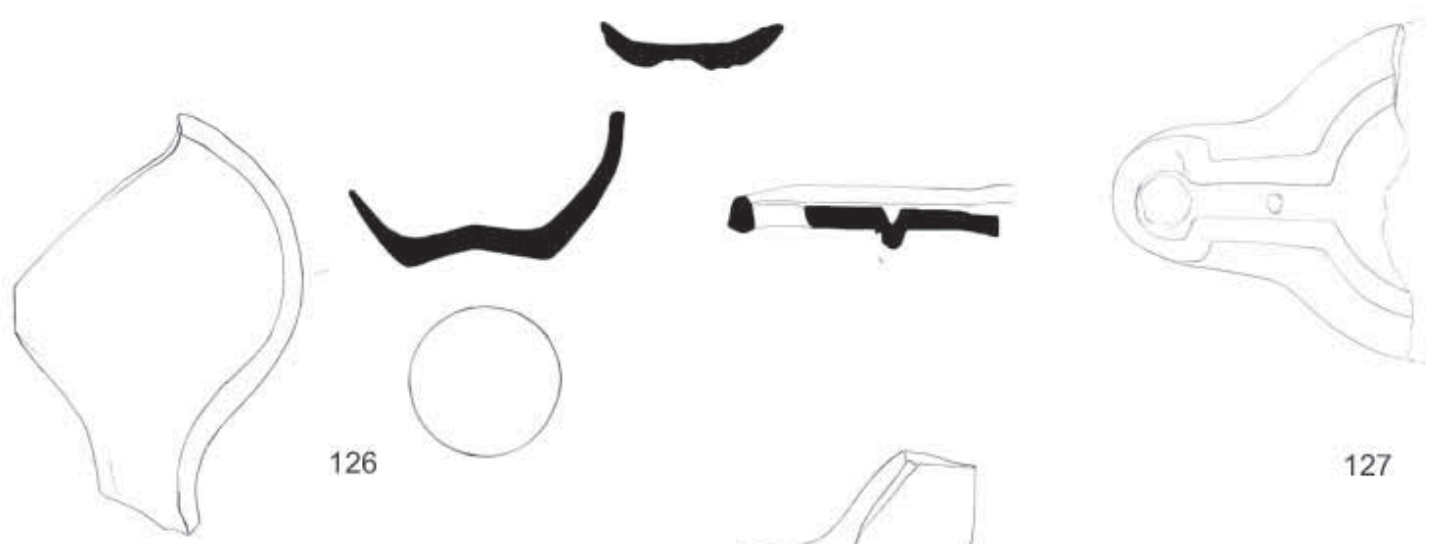

126
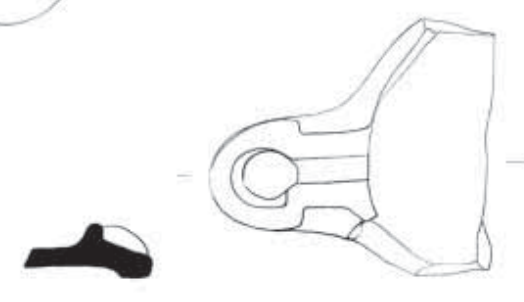

127
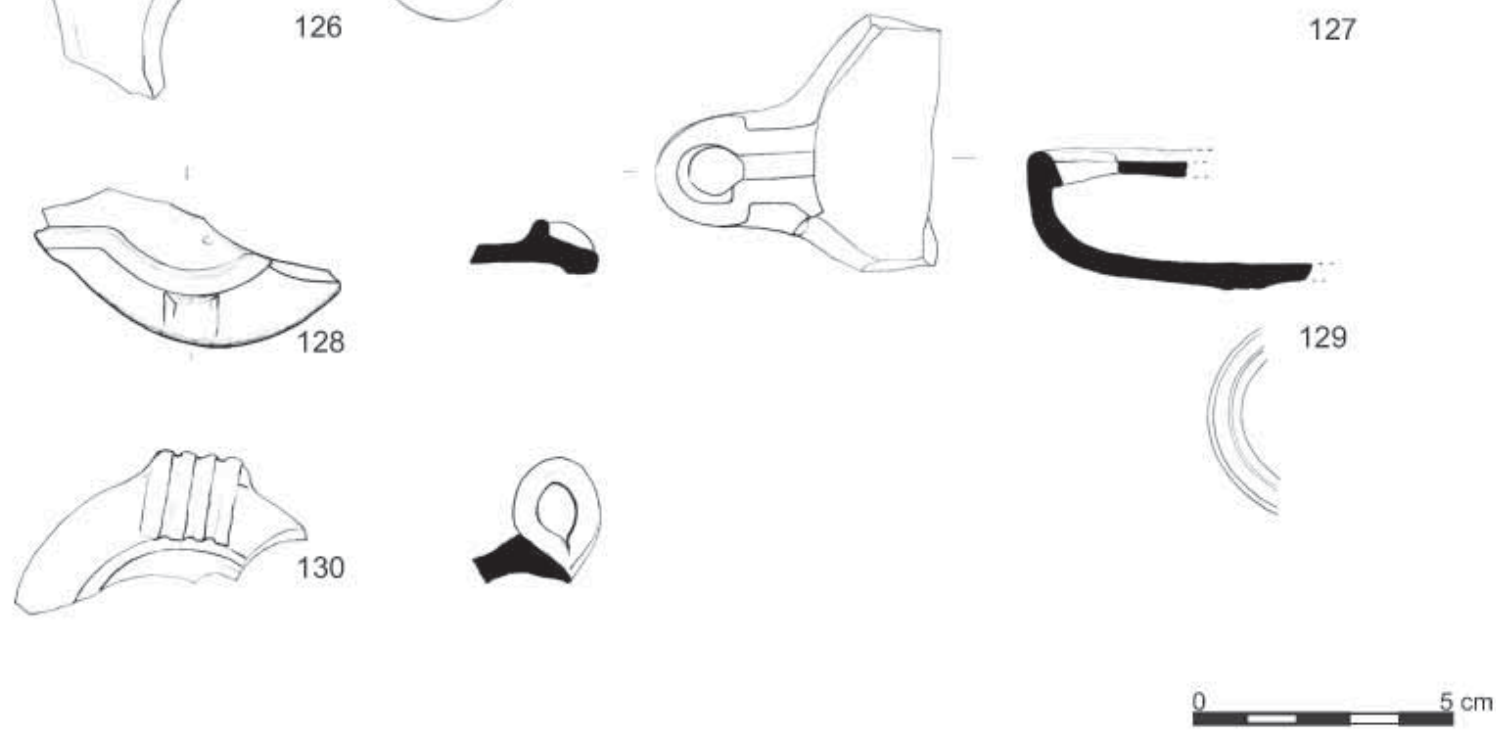

TABLA XII

120 - C: 1081, 121 - C: 1082, 122 - C: 1109, 123 - C: 1115, 124 - C: 1133, 125 - C: 1110, 126 - C: 1132 , 127 - C: $1048,128-\mathrm{C}: 1105,129-\mathrm{C}: 1119,130-\mathrm{C}: 1080$ 


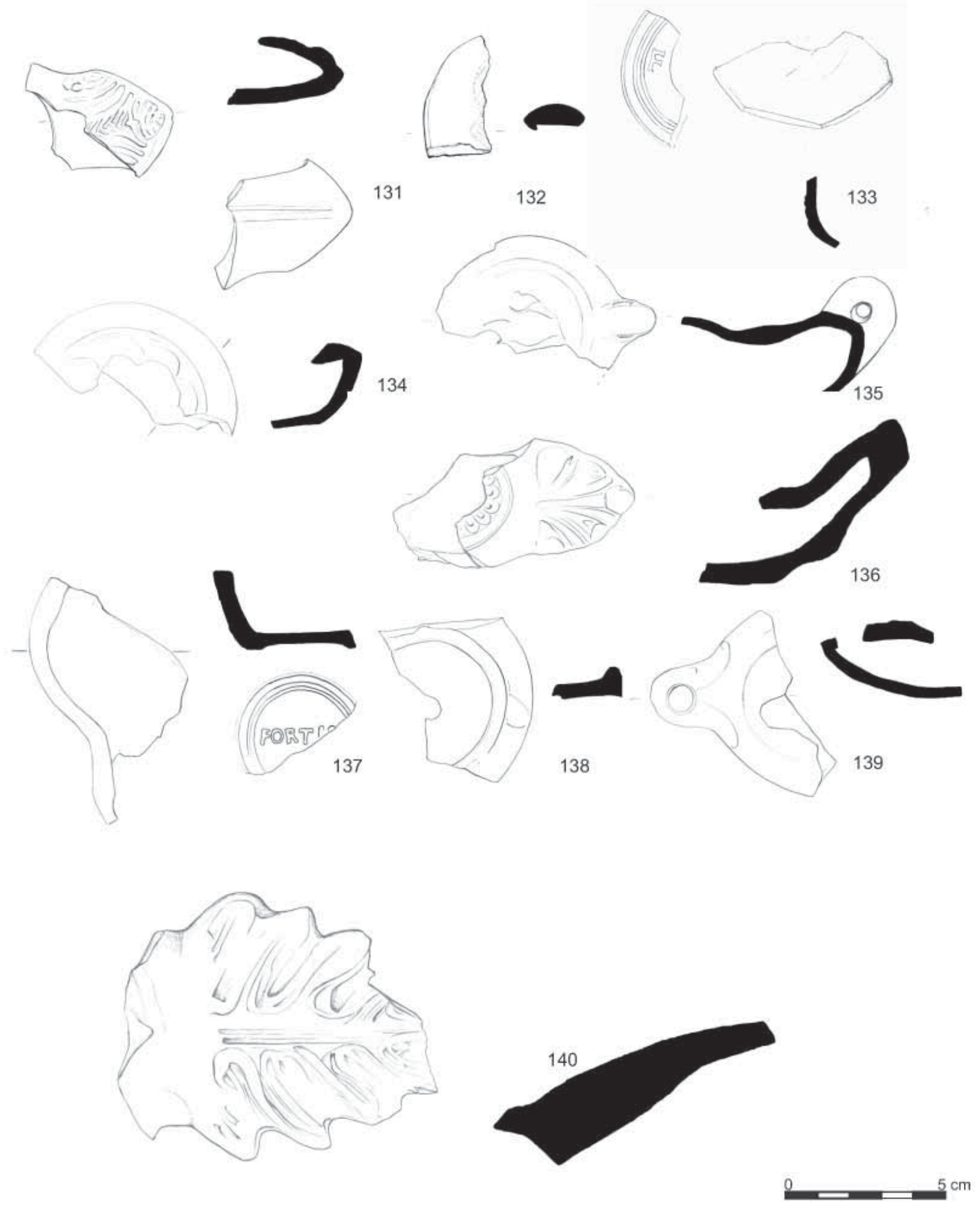

TABLA XIII

131 - C: 1188, 132 - C: 1143, 133 - C: 1040, 134 - C: 1204, 135 - C:1162, 136 - C: 1227, 137 - C: 1194 , 138 - C: $1238,139-\mathrm{C}: 1211,140-\mathrm{C}: 1259$ 

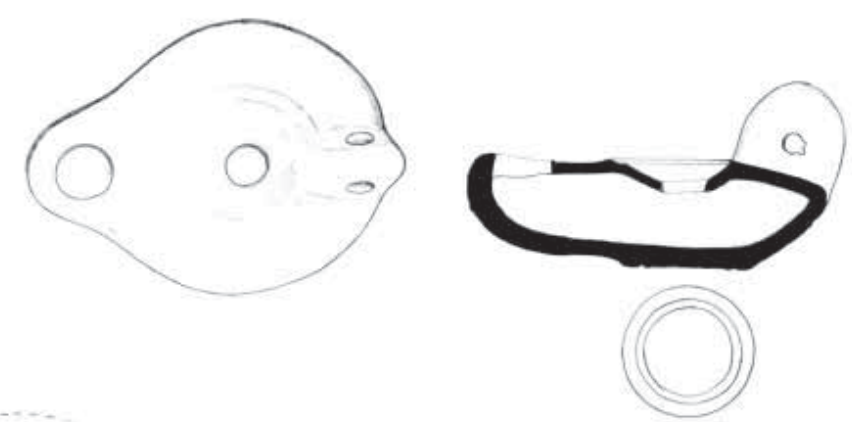

141
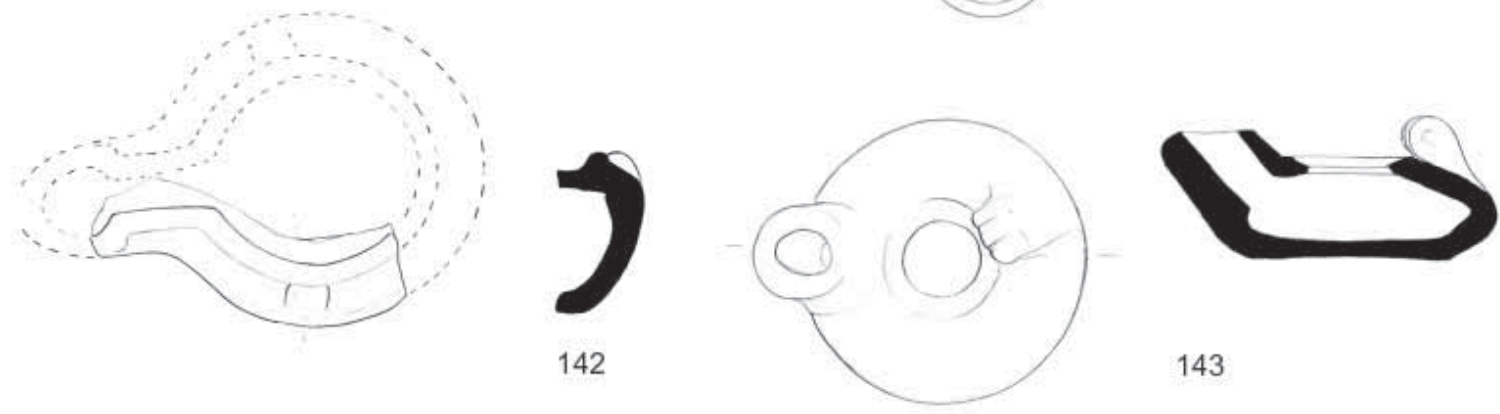

142
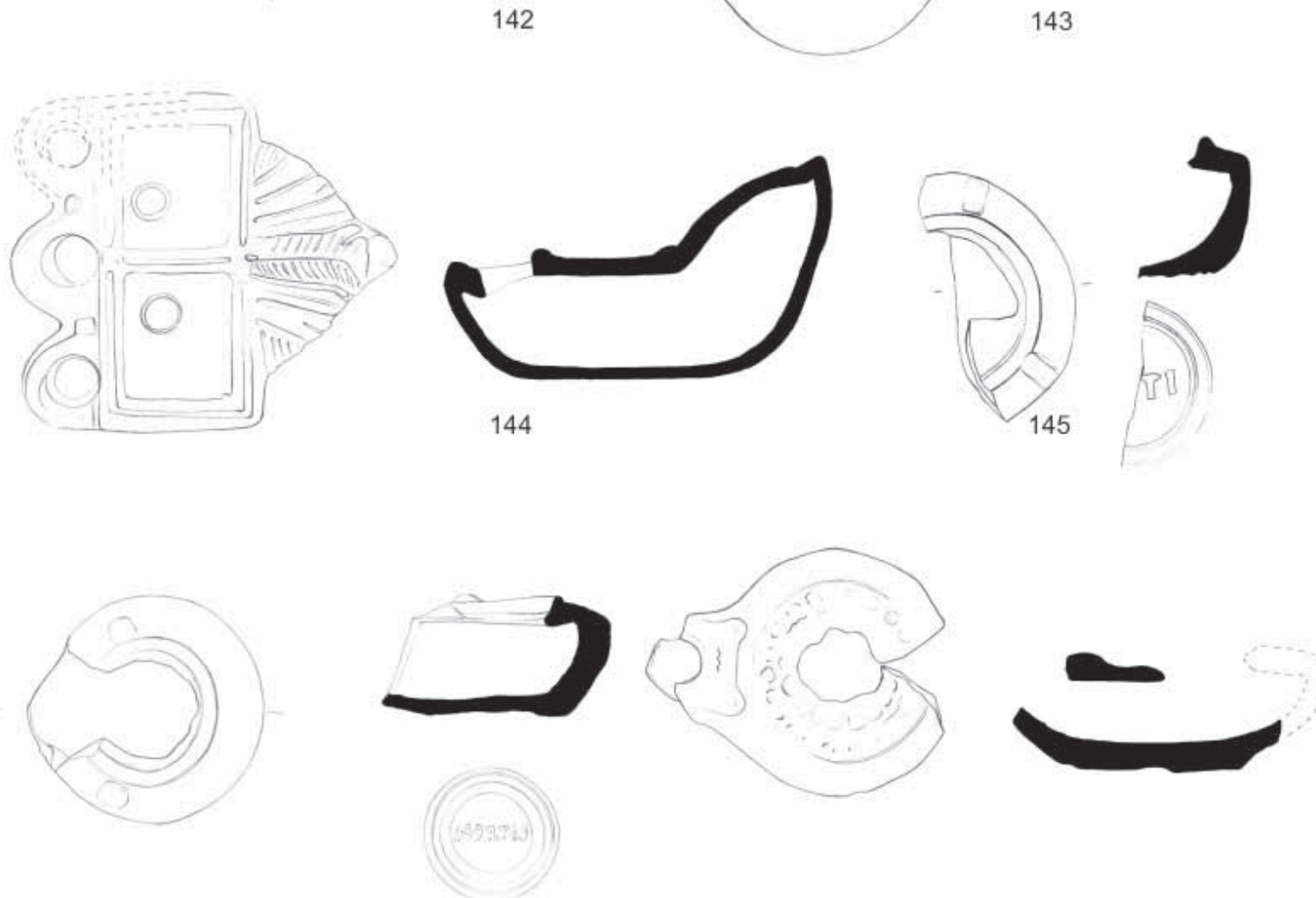

146

147

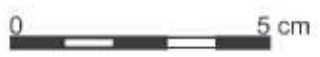

141 - C: 1164, 142 - C: 1137, 143 - C: 1163, 144 - C: 1217, 145 - C: 1208,146 - C: 1214, 147 - C: 1039 
T. XV
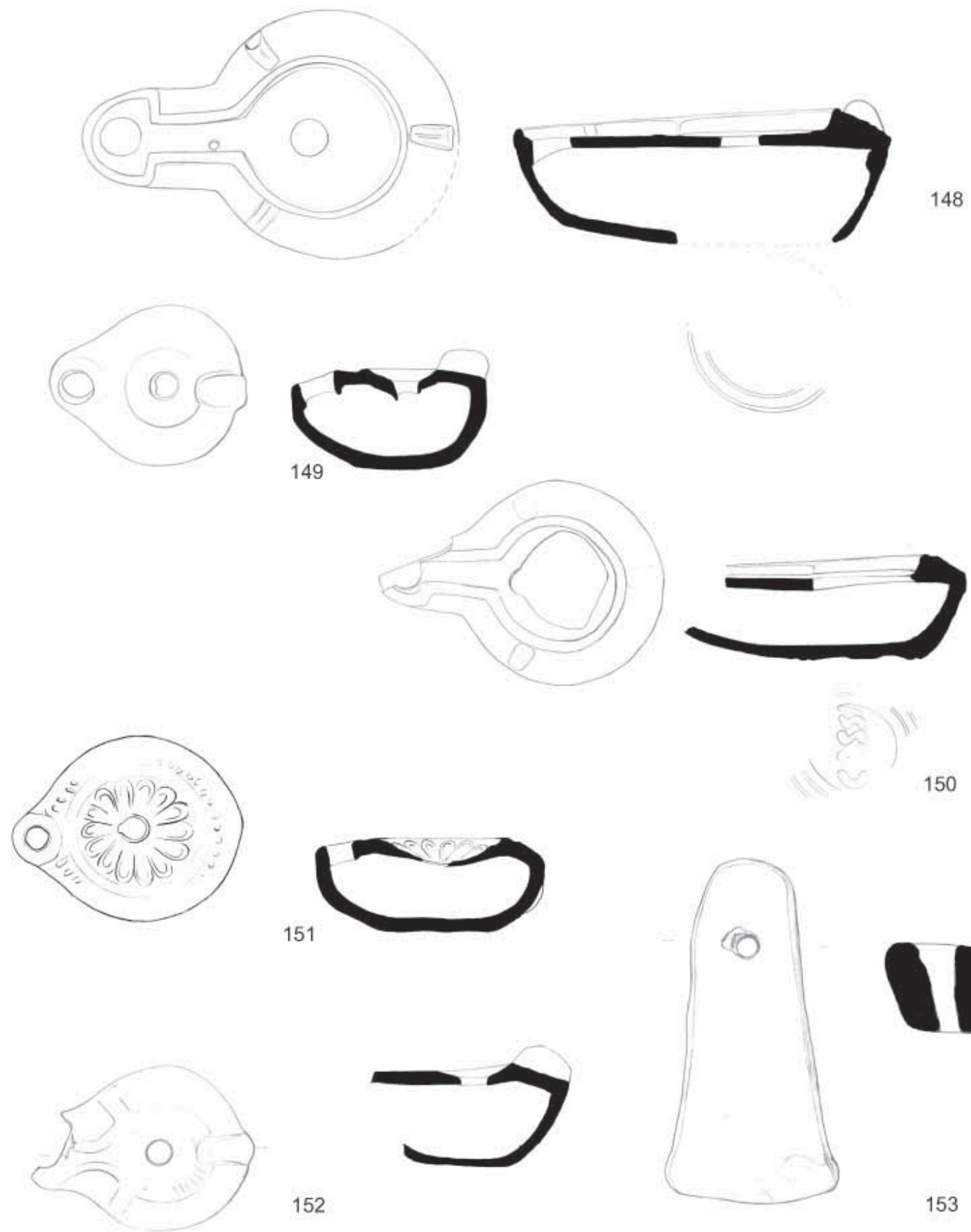

152
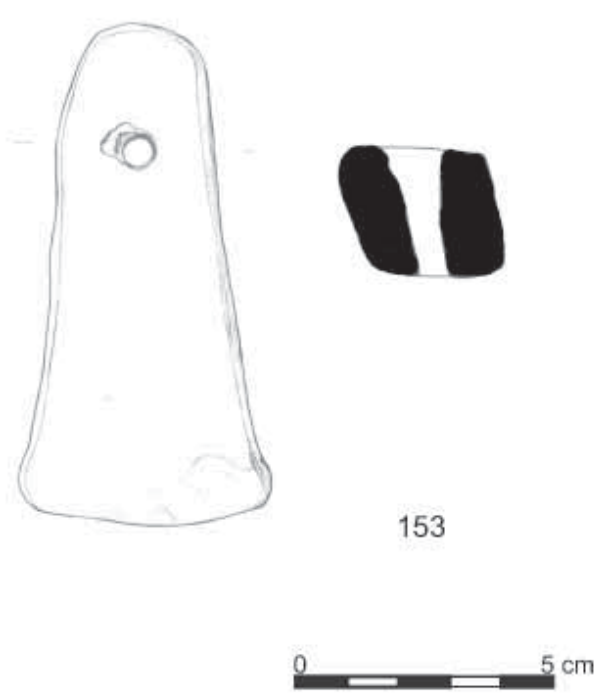

TABLA XV

148 - C: 1264,149 - C: 1276, 150 - C: 1044, 151 - C: 1290,152 - C: 1270,153 - C: 1049 


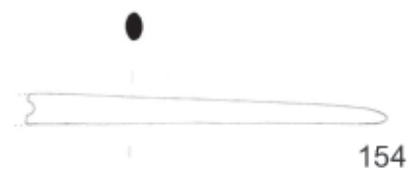

154

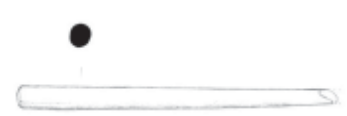

157

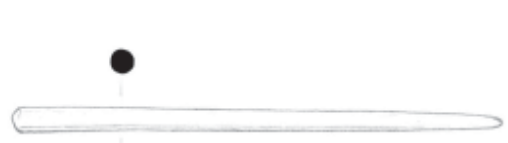

160

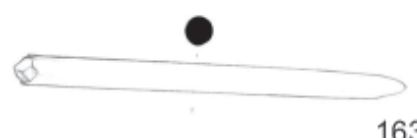

163
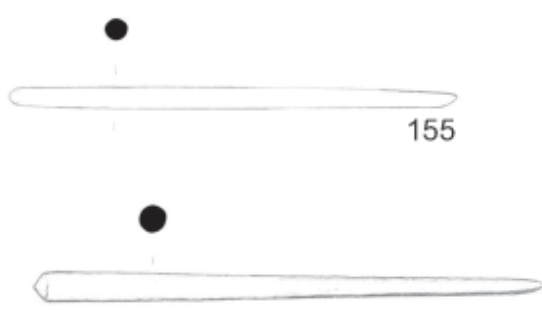

158

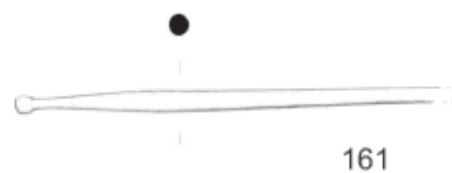

161

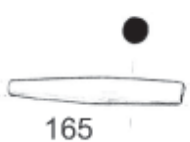

164
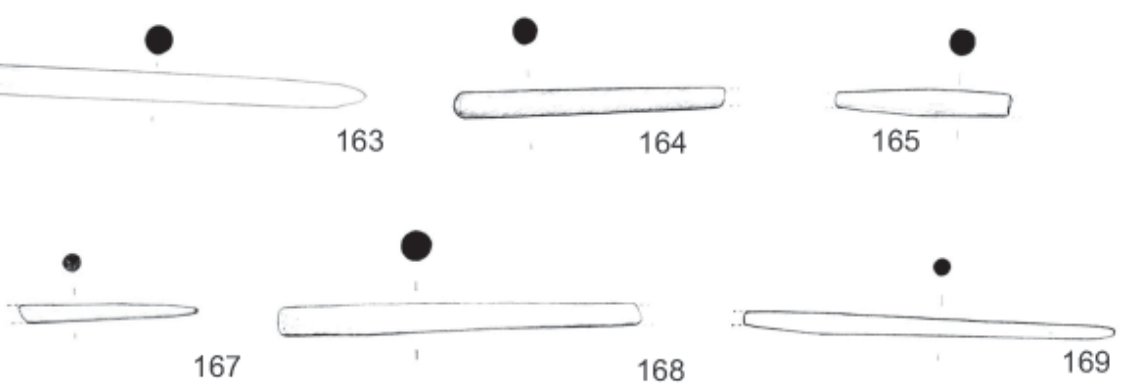

168

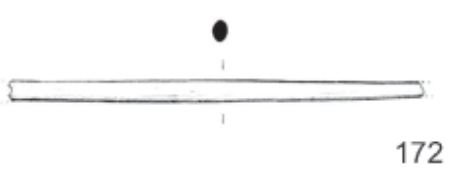

171

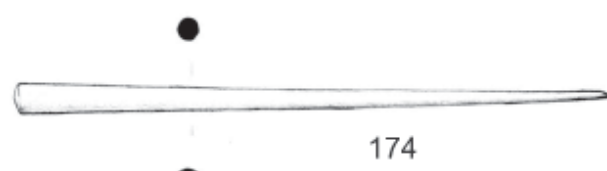

174

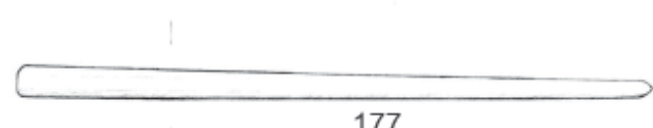

177

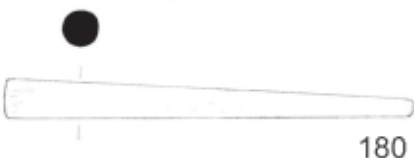

180
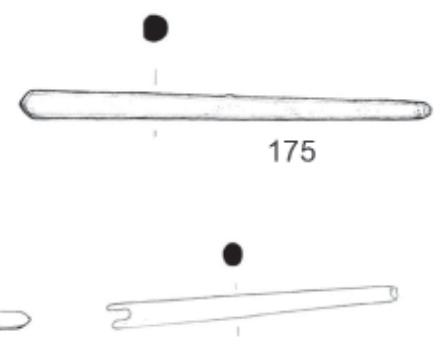

178

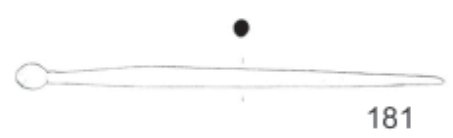

TABLA XVI

154 - C:1055, 155 - C: 1057,156 - C: 1058, 157 - C: 1059, 158 - C: 1063, 159 - C:1060, 160 - C: 1064, 161-C: 1065, 162 - C: 1066, $163-\mathrm{C}: 1070,164-\mathrm{C}: 1084,165-\mathrm{C}: 1108,166-\mathrm{C}: 1113,167-\mathrm{C}: 1114,168-\mathrm{C}: 1116,169-\mathrm{C}: 1118,170-\mathrm{C}: 1120$, $171-\mathrm{C}: 1122,172-\mathrm{C}: 1128,173-\mathrm{C}: 1135,174-\mathrm{C}: 1131,175-\mathrm{C}: 1142,176-\mathrm{C}: 1144,177-\mathrm{C}: 1146,178-\mathrm{C}: 1167,179-\mathrm{C}:$ $1178,180-\mathrm{C}: 1179,181-\mathrm{C}: 1185,182-\mathrm{C}: 1206$ 


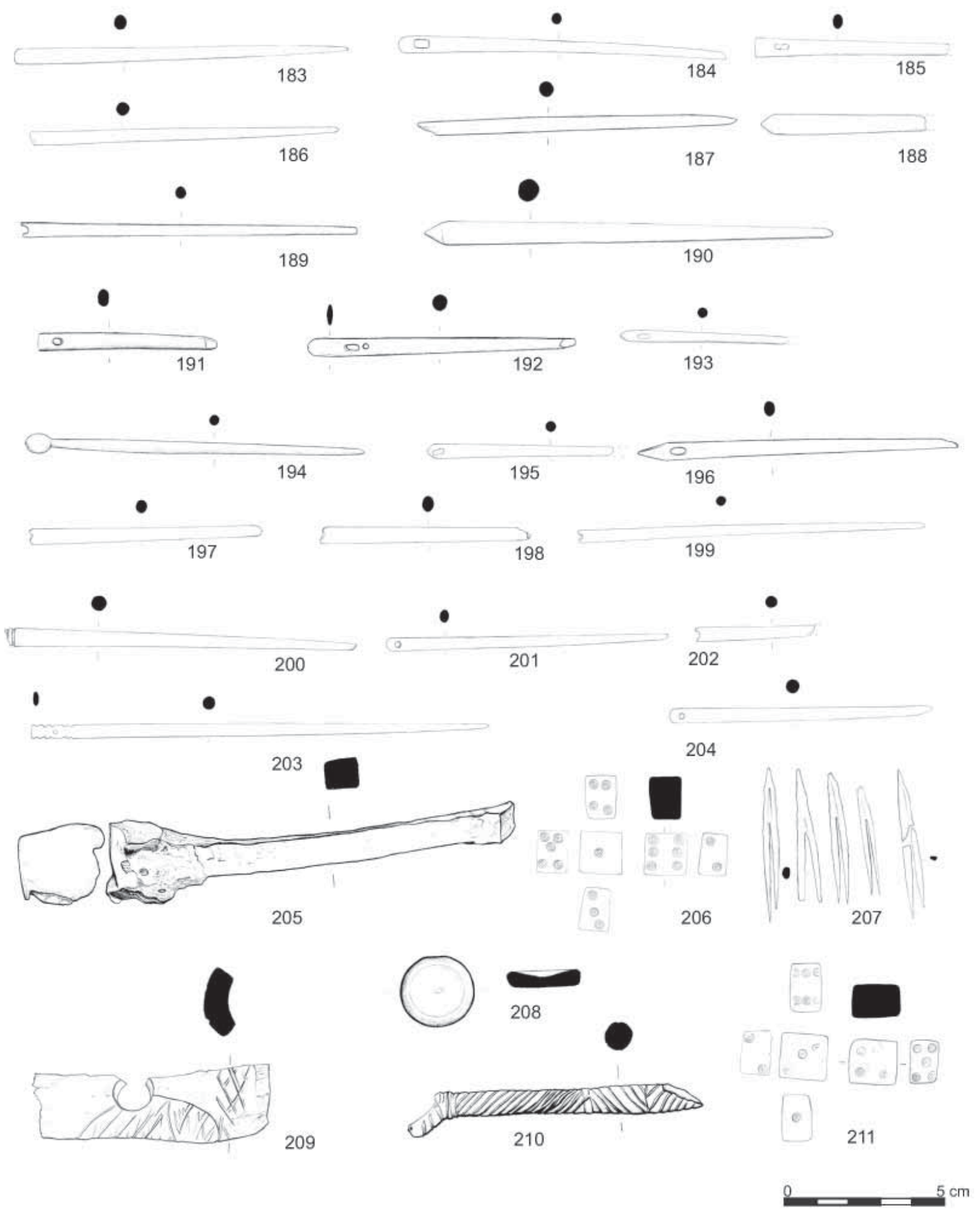

TABLA XVII

183 - C: $1172,184-\mathrm{C}: 1186,185$ - C: 1242.186 - C: $1255,187-\mathrm{C}: 1190,188-\mathrm{C}: 1220,189$ - C: 1191 , 190 - C: $1200,191-\mathrm{C}: 1139,192-\mathrm{C}: 1127,193-\mathrm{C}: 1252,194-\mathrm{C}: 1156,195-\mathrm{C}: 1225,196-\mathrm{C}: 1189$, 197 - C: 1232,198 - C: 1233, 199 - C: 1251, 200 - C: 1273, $201-$ C: 1281, $202-$ C: 1248, 203 - C: 1236, 204 - C: 1282,205 - C: 1103, 206 - C: 1219, 207 - C: 1262,208 - C: 1107,209 - C: 1212, 210 - C: 1134 , 211 - C: 1241 

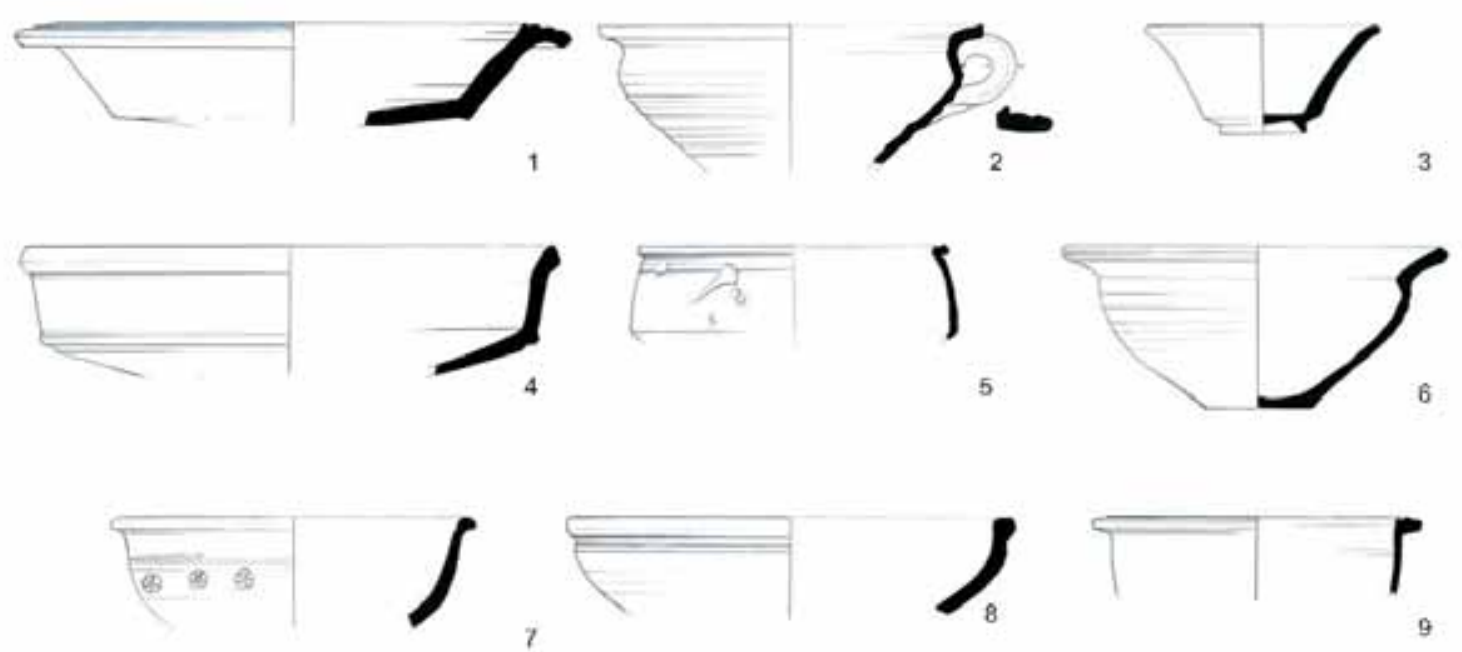

ノ.
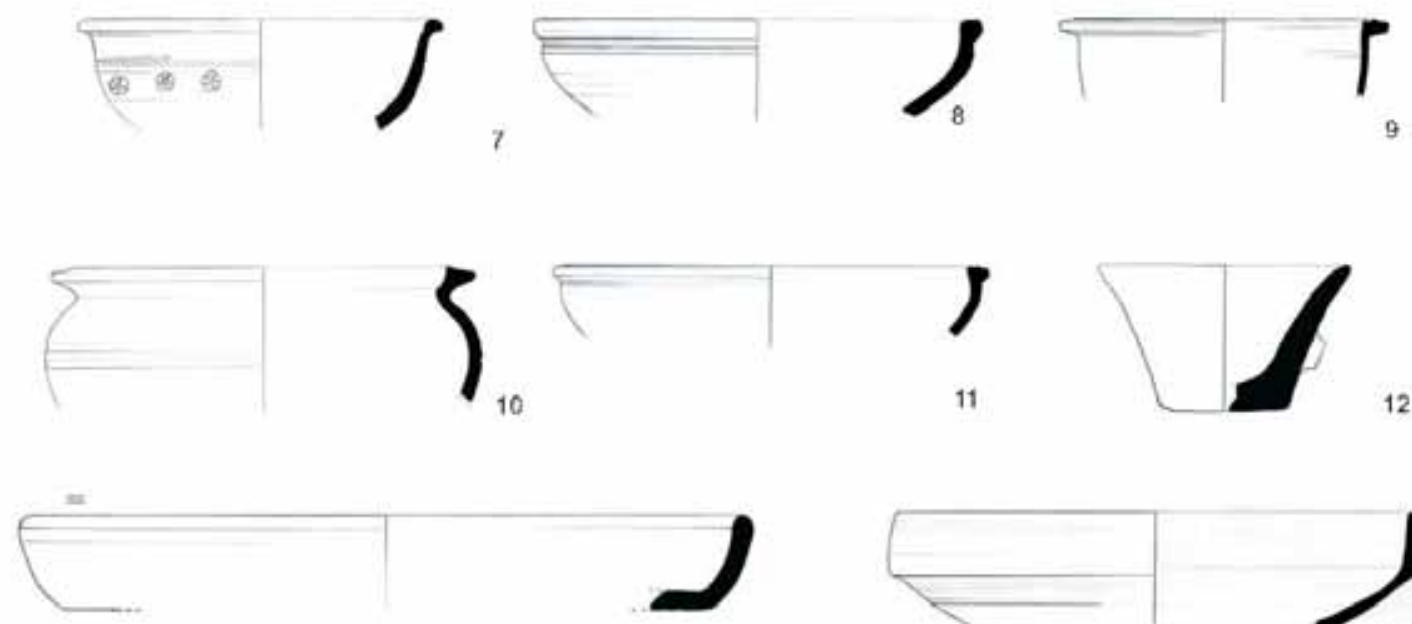

13
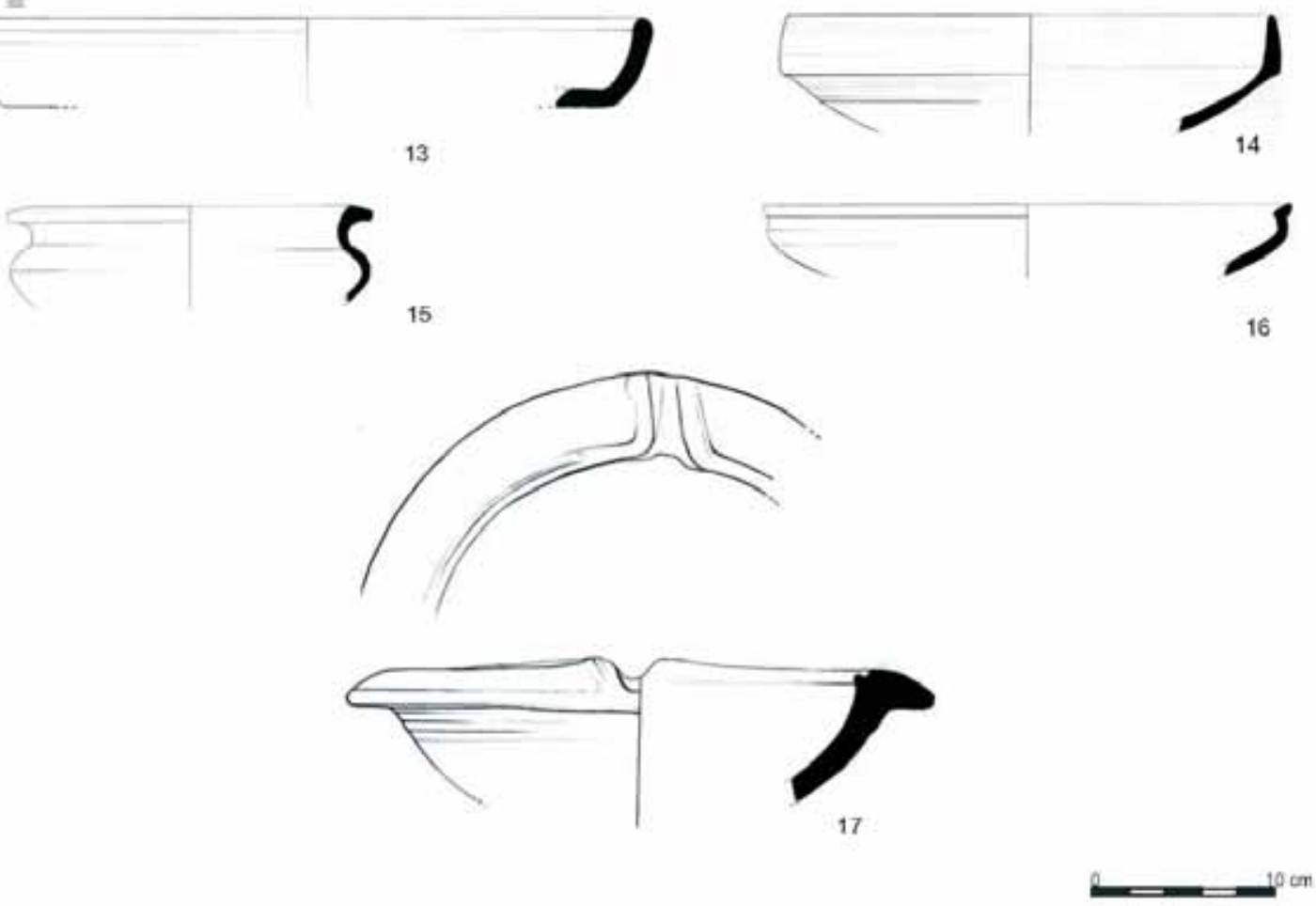

TABLA XVIII

1-17 

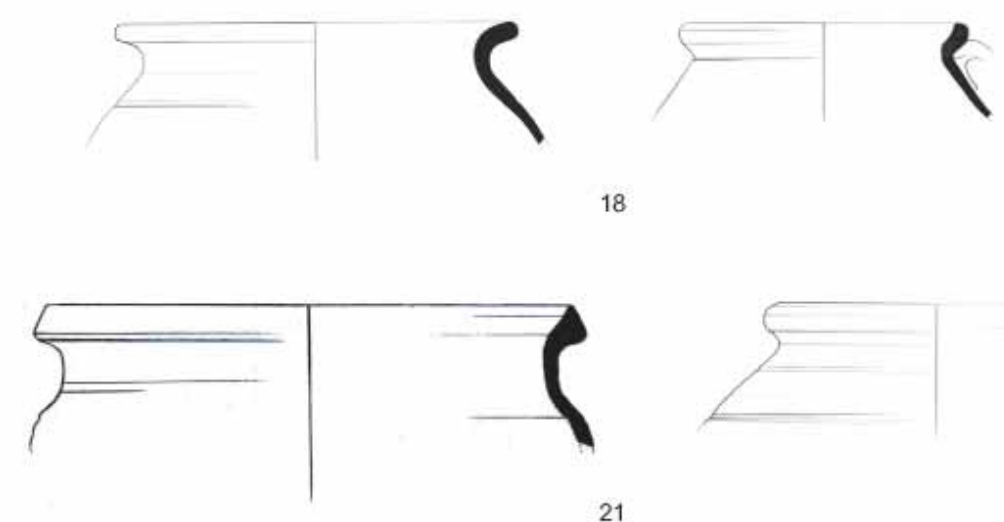

18
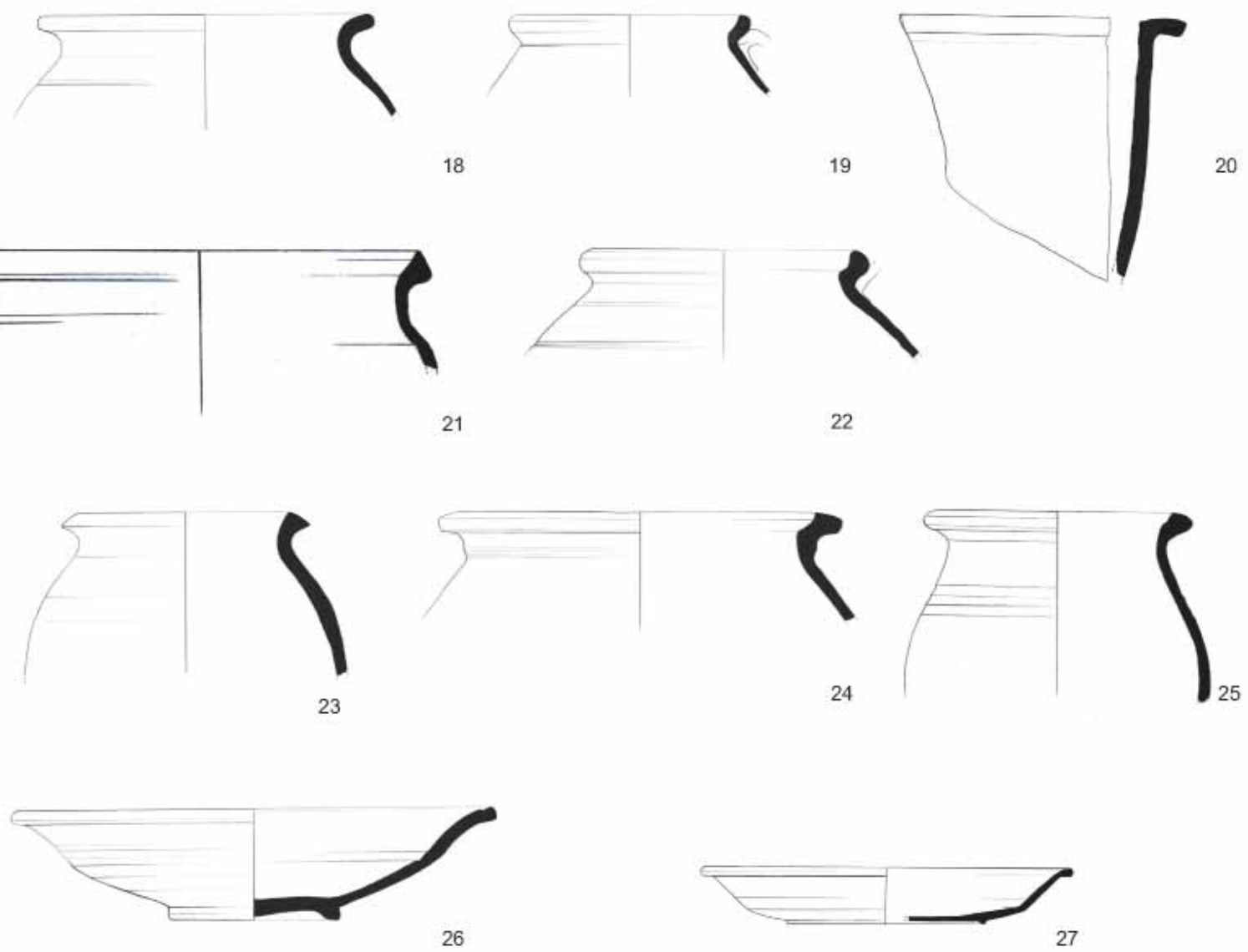
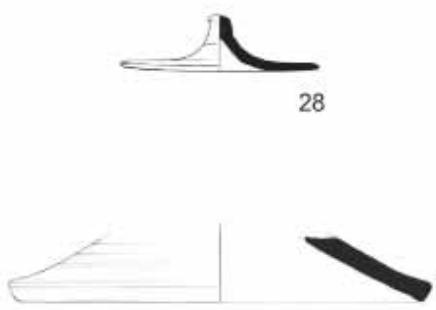

29

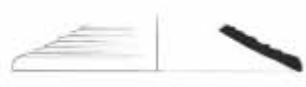

30
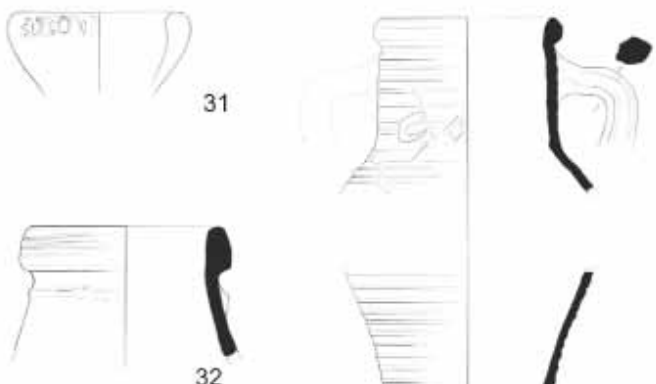

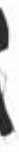

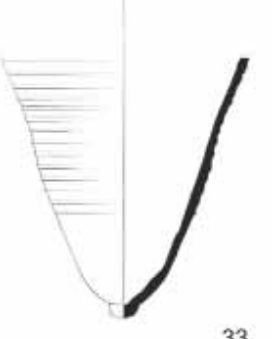

33

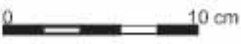

TABLA XIX

18-33 

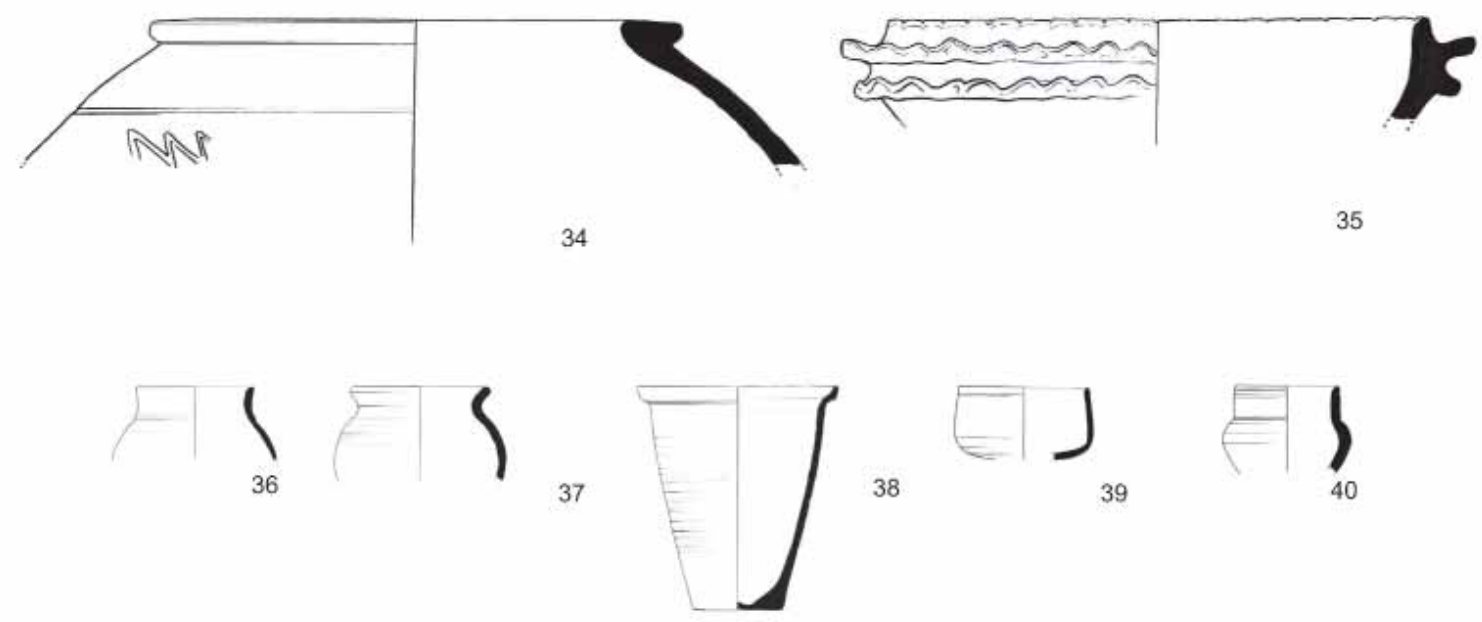

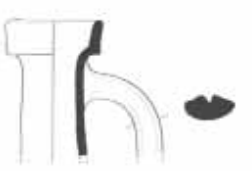

41

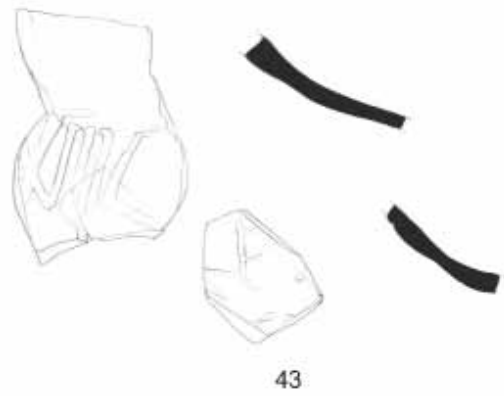

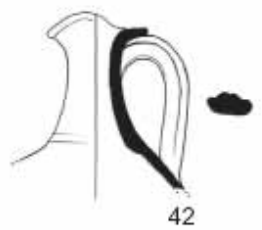

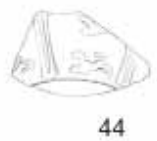




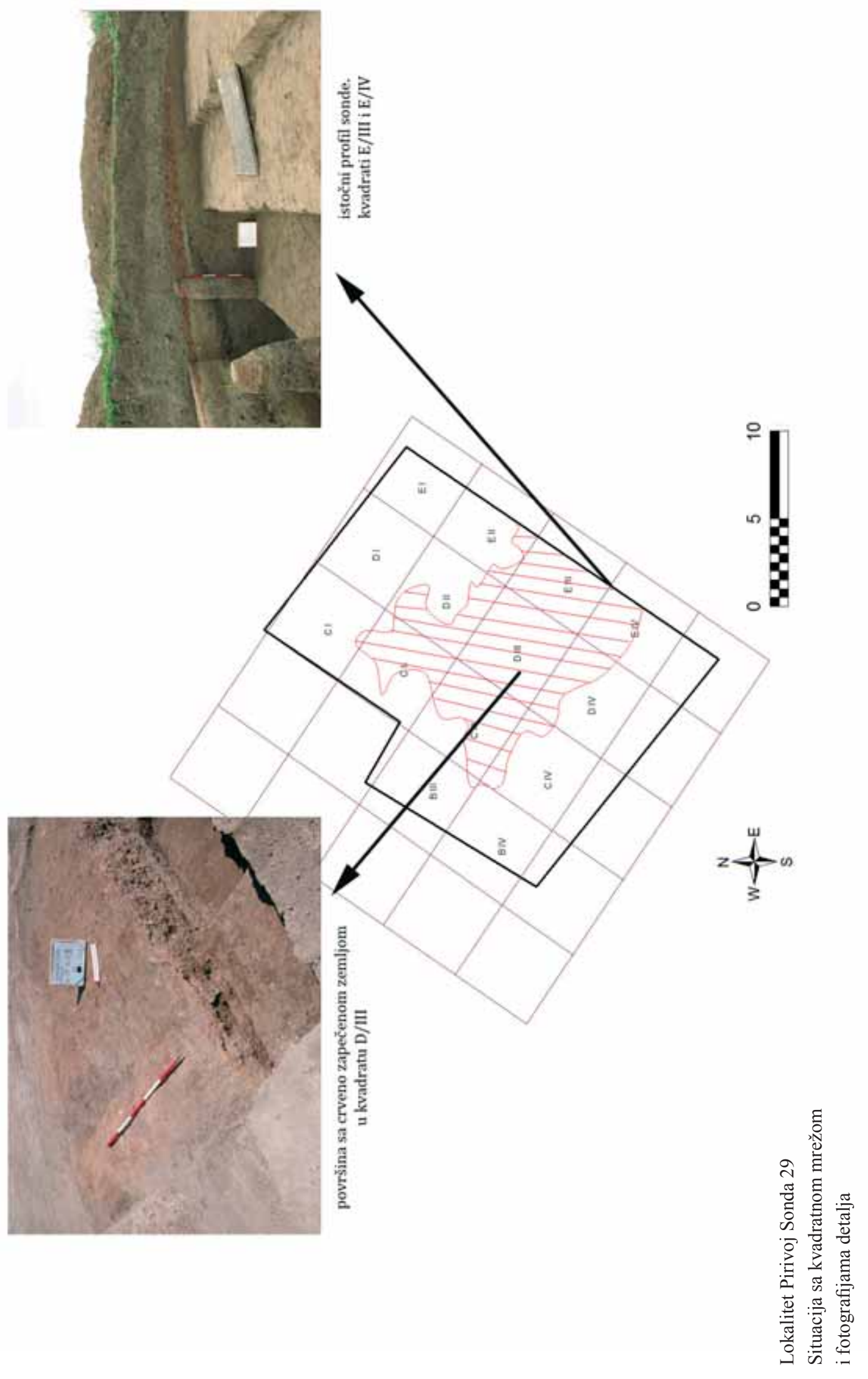

